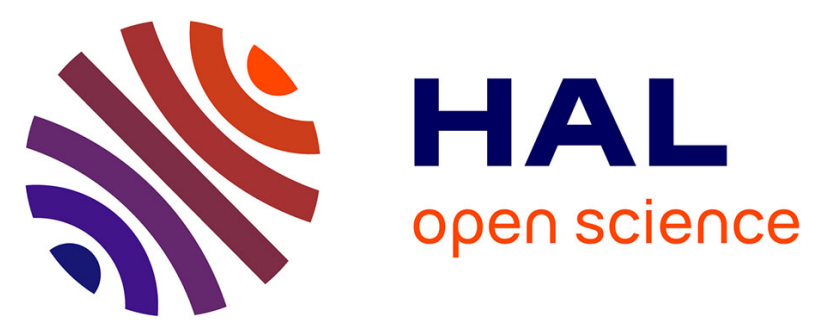

\title{
Assessing post-Pliocene deformation in a context of slow tectonic deformation: Insights from paleoseismology, remote sensing and shallow geophysics in Provence, France
}

Franck Thomas, Magali Rizza, Olivier Bellier, Jérémy Billant, Philippe Dussouillez, Jules Fleury, Vincent Ollivier, Vincent Godard, Brigitte Talon

\section{To cite this version:}

Franck Thomas, Magali Rizza, Olivier Bellier, Jérémy Billant, Philippe Dussouillez, et al.. Assessing post-Pliocene deformation in a context of slow tectonic deformation: Insights from paleoseismology, remote sensing and shallow geophysics in Provence, France. Natural Hazards, 2021, 105 (2), pp.14531490. 10.1007/s11069-020-04362-5 . hal-03143325

\author{
HAL Id: hal-03143325 \\ https://hal.science/hal-03143325
}

Submitted on 16 Feb 2021

HAL is a multi-disciplinary open access archive for the deposit and dissemination of scientific research documents, whether they are published or not. The documents may come from teaching and research institutions in France or abroad, or from public or private research centers.
L'archive ouverte pluridisciplinaire HAL, est destinée au dépôt et à la diffusion de documents scientifiques de niveau recherche, publiés ou non, émanant des établissements d'enseignement et de recherche français ou étrangers, des laboratoires publics ou privés. 


\section{Natural Hazards}

\section{Assessing post-Pliocene deformation in a context of slow tectonic deformation: Insights from paleoseismology, remote sensing and shallow geophysics in Provence, France. --Manuscript Draft--}

Manuscript Number:

Full Title:

Article Type:

Keywords:

Corresponding Author:
NHAZ-D-20-00585R2

Assessing post-Pliocene deformation in a context of slow tectonic deformation: Insights from paleoseismology, remote sensing and shallow geophysics in Provence, France.

Manuscript

Seismic hazard; slow deformation; paleoseismology; LiDAR; electric tomography; grain-size distribution; $14 \mathrm{C}$ dating; OSL dating

Franck Thomas, Ph.D.

Aix-Marseille Universite

Aix-en-Provence, FRANCE

\section{Corresponding Author Secondary} Information:

Corresponding Author's Institution:

Aix-Marseille Universite

\section{Corresponding Author's Secondary} Institution:

First Author:

Franck Thomas

First Author Secondary Information:

Order of Authors:

\begin{tabular}{|l|}
\hline Franck Thomas \\
\hline Magali Rizza \\
\hline Olivier Bellier \\
\hline Jérémy Billant \\
\hline Philippe Dussouillez \\
\hline Jules Fleury \\
\hline Doriane Delanghe \\
\hline Vincent Ollivier \\
\hline Vincent Godard \\
\hline Brigitte Talon \\
\hline
\end{tabular}

Order of Authors Secondary Information:

Funding Information:
Abstract:

\section{Çommissariat à l'Énergie Atomique et aux Dr. Franck Thomas Énergies Alternatives \\ Conseil Régional de la région PACA Dr. Franck Thomas}

The Provence region, located in the southeast of France, has experienced a few destructive earthquakes during the last centuries, such as the 1909 Lambesc earthquake or the 1509 and 1708 Manosque earthquakes. However, faults in the area experience slow slip rates $(<0.1 \mathrm{~mm} / \mathrm{yr}$ ) that preclude quantification of deformation using geodetic measurements. Active faults in Provence have long recurrence intervals and the region experiences erosion under a Mediterranean climate where surface markers of such deformation are rapidly erased. As a consequence, several faults in the region may go unnoticed despite having the potential to generate earthquakes. This work focuses on the Vinon-sur-Verdon area in Provence, where a relatively narrow fault structure, the Maragrate fault, brings into contact Miocene clays and Pliocene conglomerates. Because of its proximity to a major nuclear research facility, this fault poses a potential earthquake hazard that justifies studies aimed at gaining insight into its mechanics and Quaternary seismic activity. In this context, a multi- 
disciplinary approach has been implemented. A LiDAR campaign was undertaken to generate a $30 \mathrm{~cm}$ high-resolution Digital Elevation Model (DEM) that depicts in detail the current fault morphology. In parallel, an electrical resistivity campaign was conducted and three trenches were opened. These investigations revealed a fault contact expressed by a fault gouge zone surmounted and sealed by numerous recent Quaternary periglacial and high-energy channel units. Radiocarbon and optically stimulated luminescence dating allowed the chronological reconstruction of sediment deposition and erosion cycles and of the most recent deformation event, older than 20 ka. These investigations did not allow us to demonstrate with certainty that these deformations are of a co-seismic nature. This work highlights the difficulty of identifying faults and studying the seismic hazard in intra-continental contexts.

\section{Dear Reviewers,}

The following documents contain the main text, figure and table captions as well as supplementary text for manuscript number NH-D-20-00585. This version contains the revised manuscript as submitted on the 21st of August 2020, checked and improved for the quality of English thanks to the correction and comments from Professor Edward Anthony (native English speaker). It also includes, as requested, additional information in the acknowledgments section and a statement concerning potential conflicts of interest. The title of the article has been slightly modified as well.

In addition, following the submission of the revised manuscript on the 21st of August, two authors (Fabrice Hollender and Philippe Combes) have decided to withdraw from the list of authors. They are however included in the acknowledgments section. Finally, the affiliations of two authors have been updated (Olivier Bellier and Jérémy Billant).

Sincerely,

Franck Thomas, on behalf of all co-authors 


\section{Dear Editor,}

The following documents contain the main text, figure and table captions as well as supplementary text for manuscript number NH-D-20-00585. This version contains the revised manuscript as submitted on the $21^{\text {st }}$ of August 2020, checked and improved for the quality of English thanks to the correction and comments from Professor Edward Anthony (native English speaker). It also includes, as requested, additional information in the acknowledgments section and a statement concerning potential conflicts of interest. The title of the article has been slightly modified as well.

In addition, following the submission of the revised manuscript on the $21^{\text {st }}$ of August, two authors (Fabrice Hollender and Philippe Combes) have decided to withdraw from the list of authors. They are however included in the acknowledgments section. Finally, the affiliations of two authors have been updated (Olivier Bellier and Jérémy Billant).

Sincerely,

Franck Thomas, on behalf of all co-authors 
Assessing post-Pliocene deformation in a context of slow tectonic deformation: Insights from paleoseismology, remote sensing and shallow geophysics in Provence, France.

Franck Thomas ${ }^{1}$, Magali Rizza ${ }^{1}$, Olivier Bellier ${ }^{1,2}$, Jérémy Billant ${ }^{1,3}$, Philippe Dussouillez ${ }^{1}$, 5 Jules Fleury ${ }^{1}$, Doriane Delanghe ${ }^{1}$, Vincent Ollivier ${ }^{4}$, Vincent Godard $^{1}$, Brigitte Talon $^{5}$

1. Aix-Marseille Univ., CNRS, IRD, INRAE, Coll. De France, CEREGE, Aix-en-Provence, France

2. Aix Marseille Univ, CNRS, FR 3098 ECCOREV, F-13545, Aix-en-Provence

3. Present address : Université Côte d'Azur, IRD, CNRS, Observatoire de la Côte d'Azur, Géoazur, Valbonne, France

4. Aix Marseille Univ., CNRS, Minist Culture \& Com, LAMPEA, Aix-en-Provence, France

5. Aix-Marseille Univ., CNRS, IMBE UMR 7263, Aix-en-Provence, France

*Corresponding author: thomas@cerege.fr

Keywords: seismic hazard; slow deformation; paleoseismology; LiDAR; electric tomography; grain-size distribution; ${ }^{14} \mathrm{C}$ dating, OSL dating 


\section{Abstract}

20 The Provence region, located in the southeast of France, has experienced a few destructive earthquakes during the last centuries, such as the 1909 Lambesc earthquake or the 1509 and 1708 Manosque earthquakes. However, faults in the area experience slow slip rates $(<0.1 \mathrm{~mm} / \mathrm{yr})$ that preclude quantification of deformation using geodetic measurements. Active faults in Provence have long recurrence intervals and the region experiences erosion under a Mediterranean climate

25 where surface markers of such deformation are rapidly erased. As a consequence, several faults in the region may go unnoticed despite having the potential to generate earthquakes. This work focuses on the Vinon-sur-Verdon area in Provence, where a relatively narrow fault structure, the Maragrate fault, brings into contact Miocene clays and Pliocene conglomerates. Because of its proximity to a major nuclear research facility, this fault poses a potential earthquake hazard that

30 justifies studies aimed at gaining insight into its mechanics and Quaternary seismic activity. In this context, a multi-disciplinary approach has been implemented. A LiDAR campaign was undertaken to generate a $30 \mathrm{~cm}$ high-resolution Digital Elevation Model (DEM) that depicts in detail the current fault morphology. In parallel, an electrical resistivity campaign was conducted and three trenches were opened. These investigations revealed a fault contact expressed by a fault gouge

35 zone surmounted and sealed by numerous recent Quaternary periglacial and high-energy channel units. Radiocarbon and optically stimulated luminescence dating allowed the chronological reconstruction of sediment deposition and erosion cycles and of the most recent deformation event, older than $20 \mathrm{ka}$. These investigations did not allow us to demonstrate with certainty that these deformations are of a co-seismic nature. This work highlights the difficulty of identifying faults and studying the seismic hazard in intra-continental contexts. 


\section{1 - Introduction}

In intra-continental areas, active fault slip rates can be very low $(<0.1 \mathrm{~mm} / \mathrm{yr})$, leading to long recurrence intervals (up to several hundreds or thousands of years) for relatively strong

45 earthquakes $\left(M_{w}>6\right)$. The sub-millimeter faulting rates are usually too low to be quantified by geodetic data. A much longer time span is necessary to observe tectonic deformations (Nocquet, 2012; Fuhrman et al., 2014). In such a tectonic setting with slow activity, historic and instrumental seismicity give a first glance into the recent tectonic activity of a fault system and may provide valuable insight on the location and depth of earthquakes epicentres. Yet, linking the intensities of

50 historical earthquakes to a particular active fault is often challenging and depends on the quality of historical catalogues and the conservation of fault scarps in the landscape. At an intermediate timescale, paleoseismology fills the gap between late Holocene surface observations and longterm geological deformations. Paleoseismology studies have been conducted in various areas of slow tectonic deformation such as the lower Rhine Embayment in Germany (Vanneste et al., 1999;

55 Vanneste and Verbeek, 2001; Meghraoui et al., 2000; Grützner et al., 2016) and the New Madrid seismic zone (e.g. Thompson Jobe et al., 2020).

In the Provence region of southern France, balanced cross sections (Champion et al., 2000; Bestani et al., 2015), offsets of geological markers (Chardon and Bellier, 2003) and geodetic studies (Nocquet, 2012) confirm the slow rates of tectonic deformations $(<0.1 \mathrm{~mm} / \mathrm{yr}$ ) (Cushing et

60 al., 2008; Chardon and Bellier, 2003; Chardon et al., 2005). The region has also not experienced moderate and strong earthquakes $\left(M_{w}>5\right)$ recorded by seismological networks over the last 60 years. In addition, morphological evidence of activity along active fault segments is subdued because denudation rates are comparable or faster than fault velocities (about 30-60 mm/ka, Siame 
et al., 2004; Molliex et al., 2011; Godard et al., 2016; Thomas et al., 2017; Thomas et al., 2018;

65 Godard et al., 2020). This implies that tectonic geomorphic markers tend to be rapidly eroded away and that no single stand-alone method can be used to accurately evaluate seismic deformation. For these reasons, the investigation of current and past behaviour of active faults in slow deformation contexts, and more specifically in Provence, necessitates the implementation of a multidisciplinary methodology addressing various time and spatial scales.

70 The study area is located in southeastern Provence, a foreland basin of both the Pyrenean and Alpine orogens. It is bordered to the south by the Mediterranean Sea (see figure 1). This area is currently undergoing very slow tectonic deformations, the causes of which are still widely debated (e.g. Mazzotti et al., 2020). Various factors have been evoked: convergence of the AfricanEuropean plates, anti-clockwise rotation of the Adriatic block, gravitational collapse of the Alps

75 or even a post-glacial visco-elastic re-adjustement (Champion et al., 2000; Baroux et al., 2001; Lacombe and Jollivet, 2005; Cushing et al., 2008; Le Pichon et al., 2010; Nocquet, 2012; Bellier, 2014; Bollinger and Kuperminc, 2014; Walpersdorf et al., 2015; Mazzotti et al., 2020). Provence has been the focus of numerous structural, geomorphological, seismological and paleoseismological studies since the late $19^{\text {th }}$ century (e.g., Bertrand, 1899; Corroy et al., 1964;

80 Clauzon and Robert, 1984; Baroux et al., 2001; Chardon and Bellier, 2003; Chardon et al., 2005; Cushing et al., 2008; Molliex et al., 2011; Clauzon et al., 2011; Bestani et al., 2015; GuyonnetBenaize et al., 2015; Mazzoti et al., 2020). Structural studies have used gravity variation measurements and seismic sections to obtain maps of the main faults and the extent of the region's sedimentary basins (Terrier et al., 2008; Le Pichon et al., 2010; Espurt et al., 2012; Guyonnet-

85 Benaize et al., 2015; Bestani et al., 2016). However, the nature of seismogenic deformations in southeastern France remains unclear. For example, the 2019 November 11th Le Teil earthquake 
(see figure 1 for location) raises the question of the seismic loading and seismic source that can trigger such events in very low slip rates/shallow deformation contexts and of faults that have not experienced ruptures during the Late Quaternary (Ampuero et al., 2020; Ritz et al., 2020). This 90 highlights the fact that faults capable of creating surface ruptures can currently remain unnoticed because of very long recurrence intervals. These facts also call into question aspects of seismogenic behaviour and the concept of a seismic cycle in such contexts.

At the scale of metropolitan France (i.e., not including the French overseas territories, several of which experience significant seismic activity), discriminating whether a fault is considered as

95 active is still not straightforward and may depend on scientific or regulatory issues (Jomard et al., 2017). The database of potentially active faults (BDFA) includes faults showing evidence of Miocene or younger deformation, assuming the tectonic stress field has not experienced dramatic changes since the end of the Miocene (Jomard et al., 2017; Mazotti et al., 2020). The BDFA aims at recognizing potential seismogenic faults within $50 \mathrm{~km}$ of nuclear facilities. Our study site is

100 located in Vinon-sur-Verdon (see figure 1), only $4 \mathrm{~km}$ away from the major nuclear facilities at Cadarache which host a research centre of the CEA, the French Atomic Agency (Commissariat à l'Énergie Atomique et aux Énergies Alternatives), and the International Thermonuclear Experimental Reactor (ITER). At the Maragrate site (figure 2), a geological contact between Miocene clays and Pliocene conglomerates (figure 3) observed on a roadside outcrop raises the question of potential Quaternary deformations associated with tectonic and seismic activity. For these reasons, a key point consists in determining whether this inherited fault zone has possibly registered tectonic deformations during the Plio-Quaternary. To achieve this task, we adopted an extended multi-proxy approach that evaluates the post-Pliocene activity of this fault in a context of significant natural erosion but also important anthropogenic activity. 
In this work, we first describe the geological history of Provence and present a state of the art of past tectonic studies in the region. At our study site, the main challenge was uncovering potential deformed Quaternary surfaces and fault scarp morphologies, usually found under dense vegetation covers or in urban areas in Provence. To overcome this limitation, an airborne LiDAR (Light Detection And Ranging) survey was conducted in order to generate a $30 \mathrm{~cm}$-high resolution

115 Digital Elevation Model (DEM) that enabled a detailed geomorphological mapping of the Maragrate area. Complementary geophysical investigations were carried out to image the extent of the fault contact at depth and to drive the subsequent paleoseismic investigations. Three paleoseismic trenches were opened and one of them was sampled for sedimentology and age constraints using ${ }^{14} \mathrm{C}$ and luminescence dating, thus providing a deposition chronology. Finally, 120 we discuss these results and observations in the context of the seismic hazard of Provence.

\section{2 - Geological setting}

\section{1 - Geology of Provence}

The geology of Provence (see figure 1) consists of late Cretaceous to Paleogene (i.e.

125 Pyrenean) north and south-verging fold-and-thrust belts (Mercier, 1978; Tempier, 1987; Terrier et al., 2008; Espurt et al., 2012; Bestani et al., 2016). In northern Provence, Pyrenean structures were reactivated during the Neogene shortening that led to north- and south-verging thrust faults (Combes, 1984; Villeger and Andrieux, 1987; Chardon and Bellier, 2003). Two NE-trending crustal-scale left-lateral strike-slip fault systems (the Nîmes and Middle Durance fault systems)

130 have significant implications in the differential N-S shortening during Pyrenean and Neogene shortening events. These fault systems are inherited from Late Paleozoic strike-slip structures (Arthaud and Matte, 1974) and were reactivated as strike-slip systems during the late Cretaceous 
to early Tertiary Pyrenean orogeny (Tempier, 1987). The Pyrenean orogeny event was also at the origin of east-west ramp anticlines distributed from the Mediterranean coast up north to the 135 Ventoux-Lure mountain (e.g. Clauzon et al., 2011). These were later reactivated as normal faults during the Oligocene regional extension, thus leading to several Oligocene sedimentary basins (Roure et al., 1992; Hyppolite et al., 2012). Subsequently, the Miocene Alpine orogeny (mainly resulting from the collision of the Adriatic block and mainland Europe) led to Provence becoming the foreland basin for both the Pyrenees and the Alps (Champion et al., 2000; Baroux et al., 2001;

140 Chardon and Bellier, 2003; Molliex et al., 2011). This orogeny resulted in limited uplift and rejuvenation of pre-existing reliefs (Larroque et al., 2009; Bestani et al., 2016). Provence was further affected during the Messinian by a major Mediterranean sea-level event, the Messinian salinity crisis. This event consisted in a sea-level drop of more than 1500 metres (e.g. Clauzon, 1982; Gautier et al., 1994; Krijgsman et al., 1999; Mocochain et al., 2009; Tassy et al., 2013) that 145 deeply affected the fluvial network as a result of the variation of base level associated with intense regressive river erosion. The Messinian salinity crisis resulted in the formation of deep canyons that were later filled by marine, then continental sediments once the Mediterranean Sea became connected once again to the Atlantic Ocean approximately 5.32 Ma ago.

The Middle Durance Fault System (MDFS), a major NNE trending fault system (figure 1), 150 divides Provence into two structural domains: the western area consists of a thick Mesozoic to Oligocene sedimentary cover $(<12 \mathrm{~km})$ whereas the eastern area presents a much thinner sedimentary cover (<2 km) (e.g. Cushing et al., 2008; Le Pichon et al., 2010; Molliex et al., 2011; Bestani et al., 2015). South of the Valensole plateau, the eastern MDFS domain is characterized by a succession of compartmented fold-faults (figure 1). Three types of geological structures co155 exist in this area: a WNW-trending fold and thrust belt, a NNE-trending strike-slip fault system 
and N-trending horst and graben systems (Morabito, 1967) (figure 1). In addition, the landscape has been affected by several E-trending faults since the late Cretaceous. It is suggested that the MDFS acts as a southward transfer zone of the external Alpine front in Western Provence between the NNW-striking Digne thrust sheet and the south-verging Trevaresse thrust system (Cushing et 160 al., 2008).

During the Plio-Quaternary, tectonic deformations affected Provence but at lower rates (e.g. Cushing et al., 2008, 2014). Various studies provide evidence for late-Quaternary tectonic activity with relatively high-magnitude earthquakes for metropolitan France $\left(\mathrm{M}_{\mathrm{w}}>5.7\right)$ (Baroux et al., 2003, Chardon et al., 2005; Cushing et al., 2008, 2014; Cara et al., 2015; Manchuel et al., 2017). In particular, the Trévaresse fault (TF) is mapped as two main segments and is related to the growth of a fold developed from the Miocene through to the Pleistocene (Chardon and Bellier, 2003; Chardon et al., 2005).

\section{2 - Historical seismicity}

The SisFrance catalogue (BRGM, EDF, IRSN, e.g. Scotti et al., 2004) is the main source of information concerning historical seismicity in France (see figure 1). Historical seismicity has been documented for the past 500 years in Provence and it is both weak and sparse. Moderate to strong historical earthquakes are generally spaced in time by more than two centuries. Indeed, historical earthquakes occurred in the Manosque area in 1509 and 1708 (seismic intensities up to VIII,

175 Quenet et al., 2004), and in Volx in 1913 (intensity up to VII-VIII, Cushing et al., 2008) (see location on figure 1). These events occurred at rather shallow depths (less than $5 \mathrm{~km}$ ), are related to the MDFS and attest that this fault system mainly affects the sedimentary cover, is still currently active and produces earthquakes (Volant et al., 2000; Guignard et al., 2005; Cushing et al., 2008). 
The Lambesc earthquake on June $11^{\text {th }} 1909$, the largest in metropolitan France in the 20th century,

180 struck an area located only $15 \mathrm{~km}$ to northwest of the city of Aix-en-Provence (see Figure 1) with intensities up to IX (VIII-IX after site effects corrections, Baroux et al., 2003). The TF fault is recognized as the seismic source for the 1909 Lambesc earthquake, with an estimated moment magnitude of about 5.7 - 6.0 (e.g. Baroux et al., 2003; Chardon and Bellier, 2003; Cara et al., 2015; Manchuel et al., 2017).

185

\section{3 - Instrumental seismicity in Provence}

Earthquakes with $\mathrm{Mw}_{\mathrm{w}}>3$ have been rare in Provence since the 1960s. The seismicity of the study area is presented in figure 1 (SI-Hex catalogue, Cara et al., 2015). This catalogue documents the seismicity in France from 1963 to 2009. It aims at bringing together seismic data from the

190 Bureau Central Sismologique Français (BCSF) and the Laboratoire de Détection et de Géophysique (LDG). Jomard et al. (2017) compiled seismic data on French faults in order to reconstruct a database of potentially active faults in metropolitan France. Manchuel et al. (2017) worked on moment magnitude $\mathrm{M}_{\mathrm{w}}$ on both instrumental (SI-Hex catalogue, Cara et al., 2015) and historical seismicity (data extracted from the SisFrance catalogue, www.sisfrance.net, BRGM, 195 EDF, IRSN, 2017, e.g. Scotti et al., 2004) in continental France to develop a robust and exhaustive seismicity catalogue (FCAT-17).

The most important earthquake referenced in the SI-Hex catalogue in Provence was recorded in February 1984 approximately 15 km southeast of Aix-en-Provence and has been estimated at $\mathrm{M}_{\mathrm{w}}=3.6$ (Figure 1). Moreover, a cluster of weak seismicity is observed to the south of Aix-en-

200 Provence but it is associated with no known fault. Approximately one third of the earthquakes in metropolitan France referenced in the SI-Hex catalogue are related to human activities such as 
quarry blasts or hydropower dams (Cara et al., 2015), which could explain the presence of this particular cluster. The SI-Hex catalogue also documents seismic activity along the MDFS, with approximately 40 events at $\mathrm{M}_{\mathrm{w}}>1.8$ located in the vicinity of the fault system, the highest being

$205 \mathrm{Mw}_{w}=2.8$ in 1963. We can, however, cite two larger seismic events in the MDFS area during the 2010s, both included in the RéNASS (Réseau NAtional de Surveillance Sismique) database: the $M_{L}=2.9$ event $3 \mathrm{~km}$ from Manosque in 2010 and the $M_{L}=3.3$ event $11 \mathrm{~km}$ to the north of Manosque in 2012. The immediate surrounding of the TF is characterized by low-magnitude earthquakes, with only one event at $\mathrm{Mw}_{\mathrm{W}}>2.4$ recorded in the SI-Hex catalogue, despite the fact that this fault

210 generated the 1909 Lambesc earthquake. Similarly, the Salon-Cavaillon fault is surrounded by earthquakes with $\mathrm{M}_{\mathrm{w}}<2.5$, while around the Nîmes fault nine earthquakes with $\mathrm{M}_{\mathrm{w}}>2.5$ have been registered during the last fifty years, the largest one at $\mathrm{Mw}_{\mathrm{w}}=3.1$ in 1986.

\section{4 - Previous tectonic and paleoseismic investigations in Provence}

Paleoseismologic investigations extend the window of observation of a fault system from the last millennium to the late Quaternary. Various studies using this approach have been conducted in western Europe and France, such as in the Alps (Alasset, 2005; Hyppolite et al., 2006; Sanchez et al., 2010), the Jura Mountains (Baize et al., 2002; De La Taille et al., 2015), the Pyrenees (Alasset and Meghraoui, 2005) and the Upper Rhine (Lemeille et al., 1999; Meghraoui et al., 220 2000). These studies were carried out to identify faults producing paleo-earthquakes during the Late Quaternary and to estimate their maximum magnitude and averaged fault slip rates. With this aim in view, the Neopal online catalogue records neotectonic and paleoseismological indices in France (www.neopal.net, e.g. Baize et al., 2013), each assigned a quality attribute. In Provence, four paleoseismological events are listed as "certain" in the Neopal catalogue, two of them located 
225 on the MDFS and two others on the TF (see figure 1 for location). Trench studies in Provence mainly focus on these two structures because they correspond to the areas with the highest density of historic and instrumental seismicity.

The MDFS has been the centre of various structural and paleoseismological studies (Cushing et al., 2008; Guyonnet-Benaize et al., 2015), most notably at La Brillanne and Valveranne.

230 Concerning La Brillanne, a reverse fault parallel to the MDFS is visible on the western side of the Durance river and is compatible with the deformation pattern deduced from regional observations and focal mechanisms (Terrier, 1991; Baize et al., 2002). In Valvéranne, Ghafiri (1995) and Sébrier et al. (1997) described a late Quaternary folded alluvial fan deformed along a N35 axis that they associated to deformation along a secondary fault, parallel to the MDFS. Focal 235 mechanisms were analyzed on 27 recent earthquakes located close to the MDFS between 1999 and 2006 by Cushing et al. (2008). The majority of the 27 mechanisms are consistent with a MDFS left-lateral strike-slip faulting. The focal mechanisms were inverted by the authors using the method proposed by Carey-Gailhardis and Mercier $(1987,1992)$. It yielded a stress tensor with a strike-slip regime characterized by a $\mathrm{N} 165^{\circ}$ E-trending $\sigma_{1}$ axis.

240 Several studies have combined microtopography, detailed geomorphological mapping, and trenching to investigate the TF responsible for the 1909 Lambesc event (e.g. Chardon and Bellier, 2003, Chardon et al., 2005). A first trench opened across the main fault displays a south-verging reverse fault that brings folded Oligocene units in contact with Miocene units (Chardon et al., 2005). A second trench was opened across a 1 m-high scarp, southward of the main TF scarp, on 245 an alluvial fan resulting from the erosion of the Trevaresse ridge. In this trench, several fault offsets of more than $10 \mathrm{~cm}$ are observed, the most recent surface rupture being associated with the historical 1909 event. However, no available samples were found to date the ages of previous 
earthquakes. Using the offsets and the fault segment length, Chardon et al. (2005) estimated maximum magnitudes $\mathrm{M}_{\mathrm{w}}$ of 6.2-6.4 for earthquakes generated by this fault according to the 250 empiric laws of Wells and Coppersmith (1994).

Other potentially active faults have been studied in the region as well. West of Provence, close to the Nîmes fault, surface rupture evidence of reverse faulting, possibly associated with a strong earthquake $\left(\mathrm{M}_{\mathrm{w}}>6\right)$, has been identified (Pascual, 1978; Combes et al., 1993; Baize et al., 2002) (location figure 1). The Salon-Cavaillon fault (figure 1), located on the western border of

255 Provence, has also been the focus of various studies (Terrier, 1991; Vella and Provansal, 2000). In particular, Molliex et al. (2011) used balanced cross-sections, gravity and seismic reflection data to realize a detailed structural study of this fault system. Their observations support the fact that this fault is a major structure separating the Alpilles mountain range from the Luberon range.

In conclusion, Provence has a long-standing record of paleoseismic, historical and 260 instrumental earthquakes. However, the MDFS and TF are the only faults in metropolitan France where seismic activity has been documented at these three different timescales.

\section{3 - Geometry of the Maragrate fault}

Our study site is close to Vinon-sur-Verdon village located $60 \mathrm{~km}$ northeast of the city of Marseille (figure 1). Vinon-sur-Verdon is $8 \mathrm{~km}$ to the east of the MDFS, at the toe of the Vinon thrust, a N90 E-trending south-dipping reverse fault (Morabito, 1967; Tempier, 1987) sealed by Miocene units (figure 2). Fault kinematic measurements were performed on Jurassic limestones from the Vinon thrust (Grellet and Combes, 1995; Tassy, 2007). The inversion yields three 270 successive tectonic regimes, the relative ages of which were obtained using cross-cutting 
relationships. The oldest is a compressional tectonic regime characterized by a $\mathrm{N} 35^{\circ} \mathrm{E}$ trending $\sigma_{1}$ axis (normal to the Vinon thrust trend). It is followed by a transtensional tectonic regime characterized by a $\mathrm{N} 110^{\circ} \mathrm{E}$ trending $\sigma_{3}$ axis. The youngest is a right-lateral tectonic regime characterized by a $\mathrm{N} 115^{\circ} \mathrm{E}$ trending $\sigma_{1}$ axis. These measurements agree with the previously 275 documented geological history of Provence (e.g. Chardon and Bellier, 2003): the late-CretaceousTertiary Pyrenean compressional, the Oligocene extensional and finally the Miocene Alpine compressional tectonic events.

Our paleoseismic work was carried out $800 \mathrm{~m}$ to the south of the Vinon thrust, where an abnormal sub-vertical contact between Miocene sandstones and conglomerates units is evidenced 280 along the D554 roadside (figure 3) and hereafter named the Maragrate fault (see figure 2). The conglomerates consist of rounded pebbles in a yellow or red-brown matrix and may correspond to the continental Valensole formation. In the region, this stratigraphic formation is interpreted as the Durance-Verdon alluvial fan system prograding south (e.g. Clauzon et al., 1989; Dubar et al., 1998). Chronological data based on mammalian faunas and paleomagnetism date this formation 285 between the Late Miocene (Serravallian to Tortonian) at its base and up to the early Pleistocene at its top (Clauzon et al., 1989; Dubar et al., 1998). At Maragrate, these conglomerates were more likely deposited during the Pliocene or Early Pleistocene. This geological unit is sheared along the Maragrate fault zone, as attested by oriented and striated pebbles (Tassy, 2007 and figure 3C). Striae measurements performed on these pebbles are compatible with a dextral Plio-Quaternary 290 movement on the Maragrate fault (Grellet and Combes, 1995). These observations suggest that deformations may have occurred in this shear zone since the deposition of the conglomerates units, and they raise the question of a potential post-Pliocene tectonic reactivation of this fault segment. Even though instrumental and historical seismicity are documented west of Maragrate along the 
MDFS (figure 1), no seismic event has been recorded in the vicinity of the Maragrate area. Two

295 kilometres to the east of Vinon-sur-Verdon, a $1.5 \mathrm{~km}$-long N180 fault segment (called "ramp" in figure 2B) connects the north Vinon thrust segment $\left(\mathrm{N} 090^{\circ}\right)$ to the south Vinon thrust segment $\left(\mathrm{N} 120^{\circ}\right)$. The $\mathrm{N} 120^{\circ}$ Maragrate fault is in geometric continuation with the south Vinon thrust segment (figure 2B).

To understand the geometric relationships at depth between the north Vinon thrust segment 300 and the Maragrate fault, a geological cross-section has been proposed on the basis of published geological maps from the BRGM (1/50000th geological map of Tavernes, 1966) and the GEOTER/CEA map (2014) (figure 4, see figure 2 for geological sections location). Our geologic interpretations are speculative because no published seismic cross-sections are available in this area. The sedimentary cover is deformed and probably presents thrust-related anticlines and salt 305 tectonic structures (Tempier, 1987, Bestani et al., 2015, 2016). From north to south, an easttrending syncline of Jurassic and Cretaceous series is overthrusted by the north Vinon thrust segment, which exhibits a $\sim 20^{\circ}-30^{\circ}$ south-dipping fault plane. The Vinon thrust décollement level probably occurred at the base of Triassic series (Keuper evaporites). We propose that the thrust may reach the basement approximately $1.5 \mathrm{~km}$ below the surface (figure 4 ). The evaporites have

310 probably played a major role in the tectonic deformation and reactivation of fault segments in the area since the beginning of the Jurassic (Bollinger et al., 2010, Bestani et al. 2016); however, this remains speculative because at the surface the Triassic units from the north Vinon thrust segment are described as marly carbonates. The Maragrate fault is located at the border of the Messinian canyon of the Durance-Verdon hydrographic system. An alternative cross-section including 315 Messinian sediments is shown in the supplementary data (figure S1a). 
A borehole drilled in Vinon-sur-Verdon (BSS002HBZG, BRGM BSS database, location figure 3A) indicates that the Miocene units reach at least $260 \mathrm{~m}$ a.s.1, which corresponds to up to $60 \mathrm{~m}$ in thickness at the borehole location. Using this observation and the geological map (figure 2B), three geological sections at larger scales have been created (figure 5) in order to evaluate the vertical displacement of the Miocene and Pliocene units across the Maragrate fault (location in figure 3). Alternative cross-sections including Messinian sediments are visible in the supplementary data (figure S1b). Section 1 displays the Maragrate fault to the southeast of road D554, in an area where Miocene formations do not crop out (Figure 3). Section 2 is located directly to the southeast of Maragrate and crosses the morphological scarp documented above. The third 325 section cuts across the Maragrate valley. The three geological sections display Jurassic carbonate layers, unconformably overlain by the Miocene clay and sand units as well as the Pliocene conglomerates. Assuming that the erosional base of the unconformable Pliocene units is flat (to a first order) and that there is no significant variation in Miocene thickness, there is a slight dip towards the northwest because the base of the Pliocene lies at approximately $360 \mathrm{~m}$ a.s.1 to the southeast and only $270 \mathrm{~m}$ a.s.1 at the junction with the Verdon alluvial plain to the northwest. Taking this into consideration, we estimate that the base of the Pliocene unit is currently located approximately $30 \mathrm{~m}$ deeper to the south of the Maragrate fault than to the north (figure 2). Alternative geological cross-sections taking into account assumptions of sediment infill resulting from the Messinian salinity crisis incision under the Pliocene conglomerates are provided in 335 supplementary data. All our geological interpretations imply a significant apparent vertical component of the Plio-Quaternary movement on this dextral strike-slip fault. The Maragrate fault being subvertical at the surface, it is complicated assessing the vertical component of the faulting. 
However, the north Vinon thrust segment does not display any sign of Quaternary tectonic activity, as Miocene and Pliocene units lie unconformably on top of folded Cretaceous and Jurassic

340 units, sealing the fault plane. From our field observations, we propose that the Maragrate fault is a sub-vertical dip angle fault affecting the sedimentary sequences up to the Pliocene. Concerning its depth-anchoring, one possible geometry that can be hypothesized is that this fault is connected to the north Vinon thrust segment approximately $500 \mathrm{~m}$ below the surface (figure 4). In that case, these faults could, consequently, be the expression of strain partitioning between the north Vinon 345 thrust segment to the north and the Maragrate fault to the south.

\section{4 - Morphological and geophysical investigations}

\section{1 - High resolution LiDAR topographic data}

In recent years, high-resolution digital elevation models (DEM) have been extensively used in tectonic and geomorphological studies (Meigs, 2013; Gold et al., 2013; Cruz Nunes et al., 2015; Zielke et al., 2015). In this study, we took advantage of the ability of LiDAR technology to remove, to a certain extent, vegetation and human structures (figure 6). This is critical because, in our study area, Mediterranean vegetation and human activities impede satellite or field observations (figure 6-A). In addition, the relative similarity of denudation rates $(30-140 \mathrm{~mm} / \mathrm{ka}$, e.g. Thomas et al., 2018) and tectonic rates (30-100 mm/ka, e.g. Cushing et al., 2008) in Provence implies that tectonic fault scarps are rapidly eroded or poorly preserved in the surrounding topography (e.g. McCalpin et al., 2009). A geomorphologic analysis of the Vinon-sur-Verdon area has been performed using 
360 an airborne LiDAR survey of a total area of $13.7 \mathrm{~km}^{2}$ and a generated DEM at a resolution of 30 $\mathrm{cm} /$ pixel.

\section{2 - Methodology for electrical geophysical investigations}

Geophysical investigations were carried out in the area surrounding the Maragrate 365 morphological scarp (figure 7). Following analysis of the LiDAR data, several locations were chosen for an electrical resistivity survey in order to better document the extent of the Maragrate contact.

Electrical tomography surveys were carried out for two main purposes: (i) to image the lateral extension to the southeast and northwest of the Maragrate contact observed along the roadside, (ii)

370 to obtain precise mapping of the different alluvial/geological units in the Maragrate valley and enable pinpointing a location for paleoseismic investigations. 2D-resistivity tomography was used by employing the ABEM Lund Imaging System (SAS4000 + ES1064) with an array of 64 electrodes using a Schlumberger-Wenner reciprocal layout protocol. The electrical profiles were generated using an electrode spacing of 1 or $2 \mathrm{~m}$, resulting in profiles of $63 \mathrm{~m}$ - and $127 \mathrm{~m}$-lengths.

375 The RES2DINV software (Loke, 2003) was used to compute a 2D subsurface model representing apparent resistivity before inversion in order to obtain true resistivity. The colour scale for resistivity values has been harmonized between each profile (figure 7). In total, six profiles were produced. A first profile (VIN01/profile B) was generated to the northwest of the Maragrate valley, in the most recent abandoned alluvial plain of the Verdon river along road D952. Four additional

380 profiles (VIN02/ profile E, VIN04/ profile C, VIN07/ profile F and VIN08/ profile F) were implemented within the Maragrate valley. VIN08 was realized with a 1 m-electrode spacing instead of $2 \mathrm{~m}$ for VIN07, resulting in higher resolution but shallower data. Finally, one last profile 
(VIN06/ profile D) was obtained to the southeast of the Maragrate morphological scarp, along a path that cuts across the prolongation of the topographic scarp mapped on the LiDAR DEM.

\section{3 - Results}

A N120 vertical morphological scarp, 1-2 m-high, can be followed for more than $300 \mathrm{~m}$ on the LiDAR DEM (not observable on satellite images in figure 6-A), in the southeastward continuation of the Miocene/Pliocene contact observed along road D554 (figure 6-A and 6-B). Its current expression in the morphology probably results from differential erosion between Miocene clays to the north and indurated conglomerates to the south. The northwest continuation of the fault is not seen in the present Verdon alluvial plain and within the Maragrate valley (figure 2A). Nevertheless, it is possible that this geological contact extends towards the southeast, even though it is not visible on the LiDAR DEM because it brings in contact Valensole conglomerates on both

395 sides of the fault, preventing a clear scarp expression in the topography (figures 2 and 3 ). $\sim 1.5 \mathrm{~km}$ southeastward, in the continuation of the Maragrate morphological scarp, we map two parallel morphological scarps (oriented at $\mathrm{N} 120^{\circ}$ ) associated with knick-points (geographical coordinates in Lambert $93: 928403 ; 6294583$ ) in massive Jurassic limestones that could be related to the south Vinon thrust segment (figure 2B).

In this urbanized context, alluvial terraces and geological units were also mapped (see figure 3). Five levels of alluvial terraces (T0, T1, T2, T3 and T4) were identified, from low to high respectively, and are mostly located to the north of the Maragrate fault.

Each electrical resistivity profile displays a vertical resistivity contrast (indicated by black arrows in figure 7) between lower resistivities (in the $60-130 \mathrm{ohm} . \mathrm{m}$ range) at depth to the 405 north/northeast and higher resistivities (approximately 200-400 ohm.m) to the south/southwest. 
VIN01 displays lower resistivities on average, which may be linked to the fact that the measurement was carried out in loose and recent alluvial deposits from the Verdon river with possibly higher water and/or clay content. In the Maragrate valley, all profiles display a clear vertical resistivity contrast with conductive and resistive units, to the northeast and southwest,

410 respectively. We interpret this contrast as the rooting at depth of the red clays and conglomerates contact observed along the road; red Miocene clays and conglomerates probably correspond to conductive layers (80 ohm.m) and resistive layers (200-250 ohm.m) respectively. On top of this vertical contact we observe between 1 and $5 \mathrm{~m}$ of more resistive layers (>300 ohm.m) that we interpret as related to loose sediment deposits. VIN04, located closest to the road, has a thin

415 resistive sediment cover 1 to 5 m-thick, whereas VIN02 and VIN07 display a resistive upper layer of 4 to $5 \mathrm{~m}$ thickness. VIN08 and VIN07 were measured before opening a trench in order to compare resistivity and paleoseismic observations. Both profiles show a $1 \mathrm{~m}$-thick low-resistivity layer directly below the surface and the same resistivity contrast as described in the previous profiles. Besides, a high-resistivity patch (up to $360 \mathrm{ohm} . \mathrm{m}$ ) located just above the main vertical

420 resistivity contrast is visible in VIN08. At approximately the same depth and approximately $10 \mathrm{~m}$ to the southwest, we observe a low-resistivity $(70 \mathrm{ohm} . \mathrm{m})$ channel-like unit. Located eastward of the topographic scarp, VIN06 displays much higher resistivity values compared to the other profiles. However, there is a resistivity contrast at depth similar to that described above. We notice that the different resistivity vertical contrasts observed in all electrical profiles are aligned with the 425 topographic scarp visible in the LiDAR DEM and are in continuation of the N120 south Vinon thrust segment.

\section{5 - Paleoseismic investigations in the Maragrate valley}


The study site is located in a small town and the potential fault trace at the surface crosses private properties and/or water or underground electricity networks, which limit the possible locations for excavating a trench. To study the nature of past tectonic deformations along the Maragrate fault, two shallow trenches were excavated in the Maragrate valley in 1995 (respectively called T1 and T2) and a third trench (T3) was opened in 2016 to complement the observations (figure 8).

\section{1 - Preliminary paleoseismic trenches}

Trenches T1 and T2 were excavated on the eastern edge of the Maragrate valley to investigate the lateral extension of the Miocene-Pliocene Maragrate shear zone observed along the roadside. 440 These trenches have a $\mathrm{N} 150^{\circ}$ and $\mathrm{N} 010^{\circ}$ orientation respectively (see figure 8 for location). In both trenches, sharp contacts between red clays and conglomerates are observed (figure 9), similar to the stratigraphic contact along the road side.

In trench $\mathrm{T} 1$, the stratigraphy exposes a well-expressed $50 \mathrm{~cm}$ wide sub-vertical gouge shear zone (SZ), bringing into contact red clays to the north and yellow-beige conglomerates to the south

445 (figure 9). Miocene red clays (M) dip $70^{\circ}$ southward and are affected by numerous faults and fractures across a 4 m-wide zone. A sequence of yellow conglomerate beds (P), similar to those observed along the roadside, is observed on the northern wall of T1, dipping $70^{\circ}$ southward. Subvertical layers of orientated pebbles are visible within the conglomeratic unit (darker yellow stripes in figure 9), likely related to shear zones in loose sediments. These units are unconformably overlain by a thin organic-rich layer ( $30 \mathrm{~cm}$ thick) made of a brown soil rich in clay and sand. 
Trench $\mathrm{T} 2$ is located approximately $10 \mathrm{~m}$ to the west of $\mathrm{T} 1$ and closer to the axis of the present-day Maragrate valley. As observed in T1, red clay layers (M) dip $70^{\circ}$ to the south and are affected by secondary fractures over a $1 \mathrm{~m}$-wide zone. Fault kinematics analysis performed in T2 revealed right-lateral kinematics along various faults planes (Grellet and Combes, 1995). A $70 \mathrm{~cm}-$

455 wide gouge shear zone (SZ) is visible between the red clays (M) and yellow conglomerate units (P). However, the conglomerates are affected by cracks, do not display subvertical oriented pebbles layers and only broken pebbles are observed. T2 exposes an $80 \mathrm{~cm}$-thick sediment cover made of channel deposits sealing the fault zone. In this sequence, several channel layers made up of rounded pebbles of various sizes were logged. These channels are overlain by up to $70 \mathrm{~cm}$ of

460 brown soil rich in clay and sand. The fact that these channel units are not observed within trench T1 may be due to the fact that T2 is located closer to the valley axis, and therefore exhibits a thicker recent sediment infill. However, in both trenches, no charcoal samples were found for ${ }^{14} \mathrm{C}$ dating, thus precluding the establishment of a chronology for the deposits. Moreover, a lack of recent overlying sediments raises the question of fault reactivation during Late Quaternary, motivating 465 the excavation of a third trench.

\section{2 - Additional paleoseismic trench}

Because the VIN07 and VIN08 geophysical surveys (see section 4.3) suggest that a thicker alluvial cover may be found in the axis of the Maragrate valley, we opened a third trench (T3) with

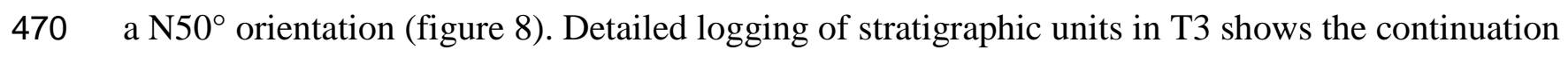
of the Maragrate fault through the Maragrate valley (figure 10). A description of each unit is given in table 1. 
We logged three separate units (M, SZ and P) that were visible for up to $150 \mathrm{~cm}$ in height at the bottom of both $\mathrm{T} 3$ walls and were similar to the units found in $\mathrm{T} 1$ and $\mathrm{T} 2$. To the northeast, 475 unit $\mathrm{M}$ consists mostly of unconsolidated red/orange sediments rich in clay and silts. To the southwest, unit $\mathrm{P}$ is made of yellow/beige conglomerates with rounded pebbles and gravels and numerous oriented or broken pebbles were also observed (figure 11). In between, we identified a purplish fault gouge unit (SZ, 80 to $100 \mathrm{~cm}$ lateral thickness), rich in clay and silt. It displayed typical signs of fluid circulation, as well as sheared, angular and broken pebbles (figure 11). In the

480 fault gouge, typical indicators (C-S shear criteria) with elongated sigmoid-shaped paleo-soils lenses were observed. The contact between the gouge and the conglomeratic unit $\mathrm{P}$ is sharp with a $70^{\circ}$ south-west dip (see figure 11). Consistent with the observations on the VIN07 and VIN08 geophysical surveys (figure 7), a thick sediment cover sealed the shear zone associated with the fault contact (figure 10A and 10B). On both walls, we logged an erosive base (EB1 in figures 11

485 and 12) between the top of the $150 \mathrm{~cm}$-thick shear zone and the base of a fine-grained silt unit with thin inter-beds of angular to sub-rounded red/brown gravels. We propose that the U1 unit consists of fluvio-glacial deposits. On the southern wall, U1 displayed a thickness of up to $3 \mathrm{~m}$, and we observed beds of gravels dipping slightly towards the south and no evidence of recent deformation. This unit is overlain by a channel (U9), up to $3 \mathrm{~m}$-thick in its middle portion, with a clear erosional 490 contact at its base (EB2 in figure 12). Unit U9 is composed of rounded yellow pebbles and gravels embedded in a fine-grained silt matrix. This channel displays imbricated pebbles with a southward dip in its lowermost part. Towards its upper section, U9 is interbedded with a horizontal layer (U9b, $30 \mathrm{~cm}$-thick) consisting of a fine-grained silt lens. We also observed a wooden fire pit approximately $1 \mathrm{~m}$ below the ground surface. To the southwest, on both trench walls, several 495 poorly consolidated channel units (U4, U5 and U6) with rounded to angular pebbles and gravels 
in a sandy and silty matrix were identified as well as another erosive surface (EB3 in figure 12). These channel deposits are re-incised by a channel base (EB4 in figure 12), later filled by a finegrained unit (U7) more than $120 \mathrm{~cm}$-thick. Another erosional surface (EB5, figure 12) was identified above U9 and U1 in the northeast part of the trench. Above the EB4 and EB5 erosive

500 bases, we find several units (U2, U3, U8, U8b, U10, U10b, U11, U12 and U13) consisting of various interbedded loose channel deposits reaching up to $4 \mathrm{~m}$ in thickness. They contain brown/beige rounded gravels and pebbles mixed in a silty and sandy matrix, with rare larger boulders (> 75mm). A last erosive base (EB6, figure 12) was logged on top of them, marking the transition with the most recent soil layers.

505 Similarly, the northern wall displays a shear zone, an erosive contact (EB1) and the same stratigraphic sequence of deposition as observed on the southern wall: the U1/U9 fluvio-glacial deposits and channels with EB2 sealing the shear zone with no indication of tectonic deformation, the U4/U5/U6/U7 channels and EB3 to the southwest lying below the EB4 erosional surface, and finally, the more recent channels (U2, U3, U8, U8b, U10, U10b, U11, U12 and U13) lying above 510 the EB5 surface and below the most recent erosional surface EB6.

Additionally, direct resistivity measurements and grain-size analysis have been performed in the trench (see table 2). The results, presented in the supplementary data, are coherent with the description above.

\section{3 - Stratigraphic age controls $\left({ }^{14} \mathrm{C}\right.$ and Optically Stimulated Luminescence)}

In order to constrain the chronology of unit deposition in trench T3, three OSL samples were collected in units $\mathrm{P}$ and $\mathrm{U} 1$ located at the bottom of T3. The preparation and measurement protocols of the USGS Denver laboratory were implemented for these samples (Sanderson and 
Murphy, 2010; Rhodes, 2011) (see table 3 and figure S3 in the supplementary data). In addition,

52050 charcoal samples were collected, mostly in channel units. Twenty of these samples were selected for ${ }^{14} \mathrm{C}$ AMS measurements performed by the Poznan Radiocarbon laboratory in Poland (see table 4). All radiocarbon age intervals have been calibrated using the OxCal software, and the cal. BP ages were calculated using IntCal 2013 calibration curves (Reimer et al., 2013) at 95.4\% probability.

525 The various OSL and ${ }^{14} \mathrm{C}$ ages bring out six main chronological groups of stratigraphic units for T3, highlighted in the log interpretation by their colour schemes (figure 12). One OSL sample (MA16-OSL3) collected within the conglomeratic unit P gives an estimated age of $195.9 \pm 30.8$ ka, providing a minimum age for the deposition of this unit (see supplementary data for more details). Until now this unit was described as related to Pliocene deposits. However, this new age

530 raises the question of potential Late Quaternary reworking of Pliocene pebbles filling the Maragrate valley channels. Nonetheless, this age is derived from a single sample, and without further geochronological constraints on the surrounding conglomeratic outcrops we cannot remove this uncertainty. OSL samples MA16-OSL1 and MA16-OSL2, both collected in the fine-grained fluvio-glacial U1 unit, yield Central Age Model (CAM) ages of $19.4 \pm 1.0 \mathrm{ka}$ and $17.9 \pm 0.7 \mathrm{ka}$, 535 respectively. Unit $\mathrm{U} 1$ could be correlated with one of the glacial periods identified in the region (MIS 1, estimated at 17000-16000 cal. BP using absolute dating by Ollivier, 2006). These two OSL ages indicate a chronological gap between the deposition of the conglomeratic $(\mathrm{P})$ and $\mathrm{U} 1$ units, consistent with the presence of the EB1 erosive surface in our paleoseismic log. Charcoal sample C29, collected in unit U1, yields a calibrated age of 31-257 cal. BP. Similarly, two samples

540 (C27 and C28), collected in unit P, yield ages between 31 and 455 cal. BP. These three samples are not in the correct stratigraphic order when compared to the OSL ages and the ages of detrital 
charcoals located in upper stratigraphic positions (figure 12). We therefore suspect that these samples may be related to roots and we consider them as outliers. Four charcoal samples (C25 and C50 on the southern wall, C26 and C36 on the northern wall), collected in the U9 channel, yield 545 ages between 9593 and 10430 cal. BP, indicating that the channel was filled at the end of the last glacial period (Lisiecki and Raymo, 2005). Four detrital charcoals (C17, C39, C44, C49) collected within the channel units U7 and U4 yield ages between 1877 and 2925 cal. BP. Another set of 8 charcoals, collected in the channels units $\mathrm{U} 2, \mathrm{U} 3, \mathrm{U} 10, \mathrm{U} 10 \mathrm{~b}$ and $\mathrm{U} 14$, suggest that a recent (< 500 years) sediment infill rich in sand, gravel and boulders took place in the Maragrate watershed

550 above erosive bases EB4 and EB5. Only one sample collected in unit U10 (C21) gives an age between 951 and 1063 cal. BP, which does not correspond to the expected stratigraphic order. Indeed, this detrital charcoal is located stratigraphically higher than the C35 sample (292-459 cal. BP) and stratigraphically lower than C19 (12 - 270 cal. BP) (figure 12). Considering the radiocarbon sample set is closely consistent with our interpretation, we suggest that sample C21

555 may contain some ${ }^{14} \mathrm{C}$ inheritance and/or has been reworked before deposition. Finally, one sample (C41) at an age of 31-255 cal. BP confirms that the uppermost soil layer consists of recent deposits, again in agreement with our preliminary paleoseismic interpretations.

\section{6 - Discussion}


Trenches T1, T2 and T3 display the same sequence of deposits: at the bottom we observe red clays (M) in contact with yellow conglomerates (P) via a shear zone (SZ). The shear zone is 565 observed in all trenches, suggesting a continuity of the fault plane for at least a hundred meters. The fault planes (dipping $70^{\circ} \mathrm{S}$ ) exhibit characteristics of deformation such as red clay material typical of fault gouges, C-S shear sigmoids. Moreover we notice numerous oriented or sheared pebbles along the fault plane, resulting from stress and deformation following deposition. Also, fault kinematics measurements in trenches $\mathrm{T} 1$ and $\mathrm{T} 2$ and $\mathrm{C}-\mathrm{S}$ criteria in $\mathrm{T} 3$ suggest that this fault

570 contact is characterized by strike-slip kinematics with a slight reverse component, which remains compatible with the geometry of the fault system. The top of unit SZ from trench T3 (figure 11) presents a dome shape. It is however difficult to evaluate if this preserved topography is the remnant of a topographic scarp later erased by the EB1 erosive base (figure 12). For this reason, we are unable to identify any co-seismic activity associated with the Quaternary deformation 575 observed in the Maragrate fault in the paleoseismic trenches.

The sediment thickness on top of the shear zone drops from $5 \mathrm{~m}$ in T3 to $1 \mathrm{~m}$ and $20 \mathrm{~cm}$ in $\mathrm{T} 2$ and T1 respectively, which confirms our geophysical interpretations. Moreover, the most recent trench T3 yields unique geochronological data that were not available for T1 and T2. Fifty charcoal samples were collected in T3 and twenty were dated, along with three OSL samples. This dataset 580 allows a better constraint on the chronology of sediment deposition and tectonic activity in Maragrate valley (figure 12). The yellow conglomerates visible in all the three trenches were described until now as Pliocene conglomerates (between 2 and 5 Ma). Our dating for MA16-OSL 3 provides a minimum age of $195.9 \pm 30.8 \mathrm{ka}$ for these conglomerates, implying that this unit had been deposited at least by the end of Marine Isotopic Stage 6 (MIS 6) and could correspond, in 585 trench T3, to a channel deposit containing reworked Pliocene pebbles. However, we are aware that 
this age is only based on a single sample with 18 measured aliquots (see supplementary data) and that this sample may be saturated or may have suffered from partial bleaching since its deposition. In addition, the sedimentological analysis from which the MA16-OSL3 sample was extracted shows very strong similarities to samples taken from undisturbed Pliocene outcrops, whereas one

590 would expect a sedimentological change in the case of reworking (see supplementary figure S2). Without further analysis, we cannot resolve this chronological discrepancy and we therefore exclude this sample in predating the age of the fault activity in the trench.

Unit U1 lying directly above the shear zone was dated at $19.4 \pm 1.0 \mathrm{ka}$ and $17.9 \pm 0.7 \mathrm{ka}$ (MA16-OSL1 and MA16-OSL2, respectively). This chronological control shows that U1 was 595 deposited before the Holocene and confirms that we may have a long stratigraphic gap between the fault activity and the first deposits on top of the EB1 erosive level. U1 is not affected by tectonic features (fault, cracks, oriented pebbles) implying that this unit seals the past activity of the shear zone. We propose that the Maragrate fault has been reactivated at least once after the deposition of the conglomeratic unit $\mathrm{P}$, thus post-dating the tectonic activity of the Maragrate contact at a minimum of $18 \mathrm{ka}$, which implies a long recurrence for this fault segment.

\section{2 - Geomorphological and tectonic relationship between the Maragrate fault and the}

\section{Vinon thrust}

The lateral extension of the Maragrate fault remains uncertain. Using LiDAR, trenches and 605 geophysical techniques, it is possible to map with certainty the N120 ${ }^{\circ}$ Maragrate fault over a length of approximately $700 \mathrm{~m}$. While this length corresponds to the smallest possible extension of this fault, several hypotheses have to be postulated in order to estimate a larger extension. In its southeastward continuation, this fault may be connected to the south Vinon thrust segment, thus 
extending the fault to $2.2 \mathrm{~km}$ in length (dotted line in figure 2). As suggested by our geophysical

610 survey (profile B in figure 7), the fault could also continue to the northwest in the current Verdon alluvial plain, extending the segment for an additional kilometre, although more geophysical data are needed to corroborate this hypothesis.

In our geological cross-section (figure 4), we connect the Maragrate fault segment to the northern Vinon thrust segment at $\sim 500 \mathrm{~m}$ depth below the surface. While the Maragrate fault

615 displays potential Quaternary (post-Pliocene) deformation as observed along a fault contact on a roadside and in paleoseismic trenches, the northern Vinon thrust segment provides no evidence for tectonic reactivation since the end of the Miocene. However, we noticed that the Maragrate fault is in geometric continuation with the south Vinon thrust segment (figure 2B). We therefore propose that the Maragrate fault could be related to a local fault partitioning, inhibiting the north Vinon

620 thrust segment since the Miocene. Such a configuration is compatible with fault kinematic analyses and consistent with a strike-slip regime.

The Maragrate segment remains a short and shallow fault and, if reactivated, has only produced earthquakes of moderate magnitude (i.e. $\mathrm{M}_{\mathrm{w}} \sim 4$ ) for a potential maximum length of 2 $\mathrm{km}$ and a depth between 0.5 and $1.2 \mathrm{~km}$ (figure 4, if the fault is not connected to the north Vinon

625 thrust segment) according to the empirical laws of Wells and Coppersmith (1994). In case of connection to the south Vinon thrust segment as well, the total surface fault trace could reach up to $5 \mathrm{~km}$ and the subsurface rupture length up to $2 \mathrm{~km}$, resulting in maximum magnitudes of $\mathrm{M}_{\mathrm{w}} \sim 5$ according to the empirical laws of Wells and Coppersmith (1994). 
From interpretative geological cross-sections (figure 5) and using the base of the Valensole formation as a stratigraphic marker, we estimate that the cumulative apparent vertical offset may reach up to $30 \mathrm{~m}$ along the Maragrate contact. This observation implies that the total geological offset has accumulated through a series of earthquakes since the deposition of the Valensole units.

635 Because quantified tectonic offsets are missing in the most recent Quaternary formations, we extrapolate a long-term slip rate using the Valensole stratigraphic marker and assuming that the regional stress field has not experienced dramatic changes since the Miocene (Jomard et al., 2017). Given the loose chronological age for the Valensole formation dated between 2.6 and $1 \mathrm{Ma}$ (Clauzon et al., 1989; Dubar et al., 1998), we deduce a slip rate ranging from 0.01 to $0.03 \mathrm{~mm} / \mathrm{yr}$.

640 Yet, several limitations have to be considered regarding this slip-rate estimation. First, we are unable to estimate horizontal cumulative displacements due to the lack of preserved offset markers. Besides, it is currently not possible to estimate when and over how long this cumulative slip has been recorded.

Nevertheless, this vertical rate is coherent with published slip rates in western Provence. For 645 example, Godard et al. (2020) identified similar rock uplift rates in the Digne-Valensole basin only $35 \mathrm{~km}$ to the north of Maragrate. There, the authors deduced a $\sim 0.021 \mathrm{~mm} / \mathrm{yr}$ differential uplift velocity along a $10 \mathrm{~km}$-transect, which is interpreted as related to active thrusting. Other slip rates ranging around $0.02 \mathrm{~mm} / \mathrm{yr}$ (Siame et al., 2004) to $0.05-0.3 \mathrm{~mm} / \mathrm{yr}$ (Chardon et al., 2005) have been proposed for the Middle Durance Fault system and the Trévaresse Fault, respectively.

\section{4 - Shear zone thickness and past tectonic activity}

As previously proposed in our geological cross-sections, the Maragrate fault is potentially short (less than $700 \mathrm{~m}$ ) and shallow $(500 \mathrm{~m})$. We also were unable to measure co-seismic slips in 
post-Pliocene units because the fault zone is sealed by erosive bases in each trench. However, the

65580 to $100 \mathrm{~cm}$ lateral thickness of the shear zone (SZ) raises the question of the recurrence and intensity of past deformation on this fault, and its compatibility with already documented empirical estimations for potential seismic events. Several studies compared fault displacements and fault thicknesses to total fault lengths (e.g. Robertson, 1983; Shipton et al., 2006). Hull (1988) presented empirical relationships between thickness of the fault gouge and displacement for various types of

660 deformation zones in quartzofeldspathic rocks. The author found a linear correlation between these two parameters. These relationships illustrate the role of strain during displacement as well as the growth of fault zones with time. Kim et al. (2004) developed the concept of fault damage zones, thus not restraining the study of the impact of faults to their surface trace. This concept relates localized zones of deformation to the structures forming them (Choi et al., 2015; Peacock et al., 665 2017). The damage zones usually form to accommodate strain or displacement variations along, around and between faults. Childs et al. (2009) compiled fault zone thicknesses against the displacement generated by seismic events produced on these faults. The relationship depends on the types of rocks involved but the authors demonstrate an overall clear increase in displacement with fault zone thicknesses. In the case of the Maragrate fault, the shear zone SZ (figure 12)

670 consists of 80 to $100 \mathrm{~cm}$-thick unconsolidated rocks and, according to the empirical study of Childs et al. (2009), this fault could generate coseismic slips ranging between 1 and $10 \mathrm{~cm}$ approximately.

These estimations are coherent with coseismic magnitude estimations for the Maragrate fault based on the empirical laws of Wells and Coppersmith (1994) mentioned in section 6.2, and also coherent with previous surface ruptures in France. Despite the lack of evidence for surface ruptures

675 reported after the 1909 Lambesc earthquake, paleoseismic investigations show that the coseismic offsets associated with past surface ruptures range from $19 \mathrm{~cm}$ to $27 \mathrm{~cm}$, which could correspond 
to Mw 6.2 to 6.4 earthquakes for the Trévaresse fault (Chardon et al., 2005). On November 11th 2019, the Mw 4.9 Le Teil earthquake occurred at a very shallow focal depth on a southeast-dipping reverse-fault. Field surveys and InSAR analysis show evidence for a discontinuous surface rupture

680 with a length of about $5 \mathrm{~km}$ and up to $15 \mathrm{~cm}$ of co-seismic uplift (Ritz et al., 2020). However, detailed geomorphic analysis of a 25-cm-resolution DEM obtained from a LiDAR survey, carried out only 10 days after the earthquake, failed to yield complete evidence of surface ruptures. These recent investigations show that seeking out past earthquakes in metropolitan France is very challenging and that evidence of small co-seismic offsets is likely erased from the landscape in a

685 few years. At the Maragrate site, we know that the topographic surface has been exposed and eroded over a period of at least 20,000 years, that recurrence times are very long and coseismic slips are probably small. For all these reasons, it is difficult to document the area's tectonic activity via classical geomorphological analysis.

\section{5 - Possible influence of salt tectonics on post-Pliocene deformations}

The majority of instrumental seismic events recorded in Provence are shallow and raise the question of the influence of salt tectonic deformations (e.g. Bollinger et al., 2010; Bestani et al., 2016). Indeed, salt tectonic structures related to Triassic deposits from the Jurassic to the late Cretaceous have been described and may have played a role during the reactivation of inherited

695 fault systems during the Pyrenean and Oligocene tectonic phases (Jannin, 2011; Bestani et al., 2015). Interestingly, from our geological interpretation, the Maragrate fault is a shallow structure rooted in Triassic sediments.

Many studies document the importance of salt tectonics in the deformation processes of different regions worldwide (e.g. Rowan and Vendeville, 2006; Callot et al., 2012; Masrouhi et 
700 al., 2013). For example, in Arctic Canada, Harrison and Jackson (2014) recognize the role of evaporite diapirs on Axel Heiberg Island. The authors document thinning and angular unconformities of diapirs, which they interpret as regional shortening. In the southern Pyrenees, Saura et al. (2016) describe various tilted basins and flaps related to the fall of large salt pillows during the late Santonian. In Turkey, Kergaravat et al. (2016) document a salt canopy that had a 705 major influence in the development and evolution of sedimentary basins. The North African orogen is also recognized as involving salt in its deformation and evolution (Masrouhi et al., 2014; Moragas et al., 2018).

In Provence, it is proposed that the deformation of the sediment cover east of the MDFS results from deep-seated basement thrusts associated with cover décollements and salt tectonics

710 (Tempier, 1987; Rangin et al., 2010; Espurt et al., 2012, 2019; Bestani et al., 2015, 2016). Similarly, salt tectonic structures are found beneath the Bandol and Sainte-Baume thrusts in Provence (Bestani et al., 2015). Bollinger et al. (2010) document the influence of aquifer elastic loading, pore pressures and hydrological mechanisms on salt diapirs in southeastern France, in Castellane, only $60 \mathrm{~km}$ to the east of Vinon-sur-Verdon. These various forcings lead to seismic 715 events of moderate magnitude $\left(\sim \mathrm{M}_{\mathrm{L}} 5\right)$ and shallow sources $(\sim 1 \mathrm{~km})$. Around Vinon-sur-Verdon, successions of Triassic evaporites are mapped and, from interpretative geological cross-sections, we propose that the Vinon thrust and the Maragrate fault could root into the Triassic evaporites approximately $1.2 \mathrm{~km}$ below the surface (figure 4). In this regard, salt-related features may have influenced Quaternary tectonic deformations of the Vinon fault system.

Furthermore, being located at the border of the Messinian canyon of the Durance-Verdon system, the Maragrate fault may also have played a role in the local deformations observed at Maragrate due to local gravitational phenomena: creep and/or compaction of Pliocene filling 
sediments of the Messinian canyon at the time of, or just after, their deposition. Or more recently, local landslide phenomena on the borders of Quaternary hydrological re-incisions. These 725 phenomena alone can hardly explain the features of the sheared zone observed in the trench, but could be involved in the most recent deformations occurring on a pre-existing tectonic fault. There is, however, no expression of a gravitational lobe visible on the high resolution LiDAR topography to strongly back this theory.

\section{6 - Local and regional sediment accumulation and incision cycles}

The incision and sedimentation cycles have been reconstructed in detail since $55 \mathrm{ka}$ in the Luberon southern foreland basin (figure 13) and compared to those more recently reported by Ollivier (2015) for Provence and the Southern Alps. The accumulation and incision phases identified for the Postglacial time period give a framework that can be compared with our

735 observations in Vinon-sur-Verdon (figure 13). Five groups of geological units (excluding the most recent soil), differentiated by their colour scheme on the geological logs, are described (figure 12). From top to bottom, the most recent channel units dated at $\sim 400 \mathrm{cal}$. BP, followed by pebble-rich channels at $\sim 2,500-2,000$ cal. BP, the U9 pebble-rich channel unit at $\sim 9,600-10,400 \mathrm{cal}$. BP, and later the periglacial fine-grained unit U1 at $\sim 18-19 \mathrm{ka}$. These groups of stratigraphic units lie in

740 discordance above erosional bases that cannot be precisely dated and can therefore only be assumed as older than the overlying sediments. The age constraints available in trench T3 display a certain consistency between local and regional accumulation in the region, validating our log interpretations and agreeing with our chronological dating (figure 13). These observations of regional incision and erosion in Provence could possibly be linked to climate variations during the 
745 Holocene (Ollivier, 2015) or to the ever-increasing pressure of human activity on the environment during the last several millennia.

These high incision/accumulation rates also raise the question of how recent tectonic scarps may be preserved in the morphology for more than a few thousand years. This is a critical aspect as active faults may have very long recurrence times (i.e. > 10 ka, Cushing et al., 2008; Bellier,

750 2014) and are associated with small coseismic offsets (i.e. a few tens of centimeters). In this regard, topographic scarps and evidence of past deformation are erased or buried in the present topography of Provence, thus leading to an underestimation of the potential sources for moderate seismic events. Moreover, we know that the absence of earthquakes $(M>6)$ in the instrumental or historical records does not truly represent the full spatial extent of the deformation.

\section{7 - Conclusion}

In intra-plate regions accommodating low strain rates, the seismological potential of active faults is usually debated. In this study, we provide an original and multi-disciplinary approach in southeastern France, in an area of slow tectonic deformation, where historical destructive earthquakes are few and instrumental seismicity is weak. Such areas are challenging in terms of paleoseismic studies, because erosion rates quickly erase topographic markers recording small and rare tectonic deformations. In order to provide new insight into this problem, we implemented high-resolution LiDAR surveys, geomorphological mapping, electrical geophysical investigations,

765 neotectonic logging and sampling, grain-size analysis as well as ${ }^{14} \mathrm{C}$ and OSL dating to study past deformation in the Maragrate area in Vinon-sur-Verdon. In the vicinity of a fault zone showing post-Pliocene evidence of tectonic deformation, we observe on the LiDAR DEM a topographic 
scarp neither visible on the field nor detected using classical remote-sensing techniques. This 300 m-long morphological scarp likely results from differential erosional processes but highlights the

770 presence of the Miocene/Pliocene fault trace as suggested by electrical geophysical surveys. This trace cannot be observed with the LiDAR DEM through the Maragrate valley because of recent incisions and alluvial deposits. Yet, despite the removal of vegetation and human structures using LiDAR techniques, detecting evidence of cumulative geomorphic offsets in this area remains challenging. Geophysical investigations were carried out in the Maragrate area evidencing the 775 geometry of deposition in the first 10-15 m below the surface. The geophysical survey helped us to pinpoint a location for a new paleoseismic trench, given the restrictions posed by authorizations for excavation.

The Maragrate fault exhibits deformation in trenches as attested by a thick shear zone incorporating typical fault gouge sediments and sheared pebbles. The fault termination is sealed

780 by a fluvio-glacial unit, dated at approximately $18-20 \mathrm{ka}$. There is no evidence of a coseismic slip associated with these deformations, probably erased by successive episodes of incision and filling of stream channels of the Maragrate valley as observed in a trench. We conclude from these observations that the Maragrate fault has experienced no deformation since at least $20 \mathrm{ka}$, implying a long recurrence time between earthquakes or no more activity in the Late Quaternary. However, 785 an older deformation, coseismic or pervasive, has been highlighted. It is difficult to estimate or predate the age of the last deformation. The OSL dating method, applied on one sample, suggests an age of $200 \mathrm{ka}$ or older.

This study illustrates the challenges we have to face when working in very slowdeformation areas and offers food for thought for studying sediment deposition and deformation 790 chronologies by bringing together complementary and recently developed methods. In the wake 
of the 2019 November 11th earthquake near Le Teil, a relatively large earthquake for metropolitan France, such methodologies could prove essential to better understand the seismic hazard in lowstrain areas where tectonic activity was underestimated.

\section{Acknowledgements}

This study was supported by the ECCOREV Research Federation (Aix-Marseille Université, INEE-CNRS, CEA, INRAE, IRSN), INSU-CNRS and the Cashima Research Project (funded by the CEA Cadarache and ITER organization). Franck Thomas benefitted from a PhD scholarship funded by the CEA and the Conseil Régional PACA. This work is also a contribution to the Labex OT-Med (n ANR-11-LABX-0061) funded by the French Government "Investissements d'Avenir" programme of the French National Research Agency (ANR) through the A*MIDEX project (n ANR-11-IDEX-0001-02). We thank Fabrice Hollender (CEA-Cadarache, DEN, France) as head of the Cashima Research Project. We thank Shannon Mahan from the USGS, Denver, for the analysis of our OSL samples. We thank Jean Claude Hippolyte (CEREGE) for his insight on local

805 geology, and Philippe Combes (Fugro France) for his active participation in this work. We also thank Laurent Froideval and his team of the University of Caen for the production of the highdefinition LiDAR DEM data. Finally, we thank Edward Anthony (CEREGE) for his thorough read-through and suggestions for the improvement of the text.

810 Conflict of interest: The authors declare that they have no conflict of interest. 


\section{References}

Alasset, P.J. and Meghraoui, M., 2005. Active Faulting in the Western Pyrenees (France): Paleoseismic Evidence for Late Holocene Ruptures. Tectonophysics, 409, 39-54.

Alasset, P.J, 2005. Thèse : Sismotectonique et identification des sources sismiques en domaine à déformation lente : Cas des Pyrénées Occidentales et des Alpes du Nord (France). Le tsunami créé par le séisme de Zemmouri (Mw=6.9, Algérie) du 21 Mai 2003.

Ampuero, J.P, Billant, J., Brenguier, F., Cavalié, O., Courboulex, F., Deschamps, A., Delouis, B., Grandin, R., Jolivet, R., Liang, C., Mordret, A., Oral, E., 2020. The November 11 8202019 Le Teil, France M5 earthquake: a triggered event in nuclear country, EGU2020-18295. https://doi.org/10.5194/egusphere-egu2020-18295

Arthaud, F., Matte, P., 1974. Les décrochements tardihercyniens du SW de l'Europe. Géométrie et essai de reconstitution des conditions de la déformation. Tectonophysics, 25, 139171.

Baize, S., Cushing, M., Lemeille, F., Granier, T., Grellet, B., Carbon, D., Combes, P., Hibsch, C., 2002. Inventaire des indices de rupture affectant le Quaternaire en relation avec les grandes structures connues en France métropolitaine et dans les régions limitrophes, Mémoire de la Société géologique de France, 2002, n 175 en co-édition l'IRSN, 142 p.

Baize, S., Cushing, E. M., Lemeille, F, Jomard, H., 2013. Updated seismotectonic zoning 830 scheme of Metropolitan France, with reference to geologic and seismotectonic data, Bull. Soc. Geol. France, 184: 225-259, https://doi.org/10.2113/gssgfbull.184.3.225.

Baroux, E., Béthoux, N., Bellier, O., 2001. Analyses of the stress field in southeastern France from earthquake focal mechanisms. Geophysical Journal International, 145(2), 336-348. 
Baroux, E., Pino, N. A., Valensise, G., 2003. Source parameters of the 11 June 1909, 835 Lambesc (Provence, southeastern France) earthquake: A reappraisal based on macroseismic, seismological, and geodetic observations, Journal of Geophysical Research, 108(B9), 2454.

Bellier, O., 2014. Tremblements de terre et aléa sismique, l'apport de la tectonique active et de la paléosismologie. nº spécial Géologues, thème "Géologie de la France, quoi de neuf ?, 180, 93-96.

Bertrand, M., 1899. La grande nappe de recouvrement de la Basse Provence, Bulletin du Service de la Carte Géologique de France, X, 68, p. 397-467.

Bestani, L., Espurt, N., Lamarche, J., Floquet, M., Philip, J., Bellier, O., Hollender F., 2015. Structural style and evolution of the Pyrenean-Provence thrust belt, SE France, Bull. Soc. Geol. France, 186, 4-5, 223-241. Provence Chain evolution, southeastern France. Tectonics, 35, https://doi.org/10.1002/ 2016 TC004115.

Blott, S.J., Pye, K., 2006. Particle size distribution analysis of sand-sized particles by laser diffraction: an experimental investigation of instrument sensitivity and the effects of particle shape, 850 Sedimentology, 53: 671-685, https://doi.org/10.1111/j.1365-3091.2006.00786.x

Bollinger, L., Nicolas, M., Marin, S., 2010. Hydrological triggering of the seismicity around a salt diapir in Castellane, France. Earth and Planetary Science Letters, 290(1-2), 20-29. http://doi.org/10.1016/j.epsl.2009.11.051 
Bollinger, L., Kuperminc, M., 2014. Seismotectonics for the seismic hazard: zoom-in on

855 France and Nepal, Revue scientifique et technique de la Direction des applications militaires, numéro 45.

Bunte, K., Abt, S.R. 2001. Sampling surface and subsurface particle-size distributions in wadable gravel- and cobble-bed streams for analyses in sediment transport, hydraulics, and streambed monitoring, Gen. Tech. Rep. RMRS-GTR-74, Fort Collins, CO: U.S. Department of 860 Agriculture, Forest Service, Rocky Mountain Research Station, 428 p.

Callot, J.P., Trocme, V., Letouzey, J., Albouy, E., Jahani, S., Sherkati, S., 2012. Pre-existing salt structures and the folding of the Zagros Mountains, in Salt Tectonics, Sediments and Prospectivity,editedbyG.I.Alsop et al., Geol. Soc. London, Spec. Publ., 363, 545-561.

Cara, M., Cansi, Y., Schlupp, A., Arroucau, P., Bethoux, N., Beucler, E., Bruno, S., Calvet, 865 M., Chevrot, S., Deboissy, A., Delouis, B., Denieul, M., Deschamps, A., Doubre, C., Frechet, J., Godey, S., Golle, O., Grunberg, M., Guilbert, J., Haugmard, M., Jenatton, L., Lambotte, S., Leobal, D., Maron, C., Mendel, V., Merrer, S., Macquet, M., Mignan, A., Mocquet, A., Nicolas, M., Perrot, J., Potin, B., Sanchez, O., Santoire, J.-P., Sebe, O., Sylvander, M., Thouvenot, F., Van Der Woerd, J., Van Der Woerd, K., 2015. SI-Hex: a new catalogue of instrumental seismicity for metropolitan 870 France. Bull. Soc. Geol. Fr. 186:3-19. http://dx.doi.org/10.2113/gssgfbull.186.1.3.

Carey-Gailhardis, E., Mercier, J.-L., 1987. A numerical method for determining the state of stress using focal mechanisms of earthquake populations: application to Tibetan teleseisms and microseismicity of Southern Peru, Earth Planet. Sci. Lett., 82, 165-179. 
Carey-Gailhardis, E., Mercier, J.-L., 1992. Regional state of stress, fault kinematics and 875 adjustments of blocks in a fractured body of rock: application to the microseismicity of the Rhine graben, J. Struct. Geol., 14(8/9), 1007-1017.

Champion, C., Choukroune, P., Clauzon, G., 2000. La déformation post-Miocène en Provence occidentale. Geodinamica Acta, 13(2), 67-85.

Chardon, C., Bellier, O., 2003. Geological boundary conditions of the 1909 Lambesc 880 (Provence, France) earthquake: Structure and evolution of the Trevaresse ridge anticline, Bull. Soc. Geol. Fr., 174, 497-510.

Chardon D., Hermitte D., Nguyen F., Bellier O., 2005. First paleoseismological constraints on the strongest earthquake in France (Provence) in the twentieth century, Geology, 33, 11, 901904.

Childs, C., Manzocchi, T., Walsh, J. J., Bonson, C. G., Nicol, A., Schöpfer, M. P. J., 2009. A geometric model of fault zone and fault rock thickness variations, Journal of Structural Geology, 31(2), 117-127. http://doi.org/10.1016/j.jsg.2008.08.009

Choi, J-H., Edwards, P., Ko, K., Kim, Y-S., 2015. Definition and classification of fault damage zones: A review and a new methodological approach, Earth-Science Reviews. 152. 890 https://doi.org/10.1016/j.earscirev.2015.11.006.

Clauzon, G., 1982. Le canyon messinien du Rhône : une prevue decisive du “dessicated deepbasin model" (Hsü, Cita et Ryan, 1973). Bull Soc. Geol. France, 24, 597-610. 
Clauzon, G., Robert, C., 1984. La sédimentation argileuse du miocène supérieur continental dans le bassin de Cucuron/Basse Durance (Provence, France) : implications paléogéographiques. 895 Paléobiologie continentale, Montpellier, XIV, 2, p. 205-224.

Clauzon, G., Aguilar, J. P., Michaux, J., 1989. Investigation of the time-sedimentation relation thanks to examples taken from the French Mediterranean Neogene, B. Soc. Geol. Fr., V, 361-372, https://doi.org/10.2113/gssgfbull.v.2.361.

Clauzon, G., Fleury, T. J., Bellier, O., Molliex, S., 2011. Morphostructural evolution of the 900 Luberon since the Miocene (SE France), Bulletin de la Société Géologique, 182, 2, 95-110.

Combes, P., 1984. La tectonique récente de la Provence occidentale : microtectonique, caractéristiques dynamiques et cinématiques. Méthodologie de zonation tectonique et relations avec la sismicité. - Thèse de Doctorat, Strasbourg, 182p.

Combes, P., Carbon, D., Cushing, M., Granier, T., and Vaskou, P., 1993, Mise en évidence 905 d'un paléoséisme pléistocène supérieur dans la vallée du Rhône: Implications sur les connaissances de la seismicité en France: Paris, Académie des Sciences Comptes Rendus, v. 317, p. 689-696.

Corroy, G., Tempier, C., Durand, J.-P., 1964. Evolution tectonique de la montagne SainteVictoire en Provence. C. R. Acad. Sci. Fr., 258 (D), p. 1556-1557.

Cruz Nunes, F., Delunel, R., Schlunegger, F., Akçar, N., Kubik, P. W., 2015. Bedrock bedding, landsliding and erosional budgets in the Central European Alps, Terra Nova, 27(5), 370378. 
Cushing, E. M., Bellier, O., Nechtschein, S., Sébrier, M., Lomax, A., Volant, P., Dervin, P., Guignard, P., Bove, L., 2008. A multidisciplinary study of a slow-slipping fault for seismic hazard 915 assessment: the example of the Middle Durance Fault (SE France). Geophysical Journal International, 172(3), 1163-1178.

Cushing E. M., Baize, S., Nechtschein, S., Bellier, O., Scotti, O., Baumont, D., 2014. Contexte sismotectonique régional: géologie, sismotectonique et sismicité historique de la région de Manosque. Ouvrage collectif: Le tremblement de terre de 1708 à Manosque: apport d’une étude 920 historique et archéologique à l'évaluation du risque sismique en Moyenne Durance. - Ouvrage collectif, Groupe APS Editeur, Alès, 19-44.

De La Taille, C., Jouanne, F., Crouzet, C., Beck, C., Jomard, H., De Rycker, K., Van Daele, M., 2015. Impact of active faulting on the post LGM infill of Le Bourget Lake (western Alps, France), Tectonophysics, 664, 31-49.

Dubar, M., Aguilar, J. P., Chaline, J., Michaux, J., Semah, F., 1998. Chronological data (mammalian faunas, paleomagnetism) on the Plio-Pleistocene deposits from the top of the Valensole Basin: morphodynamic implications, Géologie de la France, 1, 57-68.

Espurt, N., Hippolyte, J. C., Saillard, M., Bellier, O., 2012. Geometry and kinematic evolution of a long-living foreland structure inferred from field data and cross section balancing, 930 the Sainte-Victoire System, Provence, France. Tectonics, 31, TC4021.

Espurt, N., Wattellier, F., Philip, J., Hippolyte, J-C., Bellier, O., et al., 2019. Mesozoic halokinesis and basement inheritance in the eastern Provence fold-thrust belt, SE France. Tectonophysics, Elsevier, 2019, 766, pp.60-80. https://doi.org/10.1016/j.tecto.2019.04.027 
Fuhrmann, T., Westerhaus, M., Zippelt, K., Heck, B., 2014. Vertical displacement rates in 935 the Upper Rhine Graben area derived from precise leveling, J. Geod., 88(8), 773-787.

Galbraith, R.F., Roberts, R.G., 2012. Statistical aspects of equivalent dose and error calculation and display in OSL dating: An overview and some recommendations, Quaternary Geochronology, 11, 1-27. http://doi.org/10.1016/j.quageo.2012.04.020

Gautier, F., Clauzon, G., Suc, J.P., Cravatte, J., Violanti, D., 1994. Age et durée de la crise 940 de salinité messinienne. C. R. Acad. Sci. Paris, Ser. IIa 318, 1103-1109.

Ghafiri A., 1995. Paléosismicité de failles actives en contexte de sismicité modérée : application à l'évaluation de l'aléa sismique dans le SE de la France. Thèse Univ. Paris-Sud. Orsay.

Ghilardi, M., Psomiadis, D., Cordier, S., Delanghe-Sabatier, D., Demory, F., Hamidi, F., Paraschou, T., Dotsika, E., Fouache, E., 2012. The impact of rapid early- to mid-Holocene 945 palaeoenvironmental changes on Neolithic settlement at Nea Nikomideia, Thessaloniki Plain, Greece. Quaternary International 266, 47-61. https://doi.org/10.1016/j.quaint.2010.12.016.

Godard, V., Ollivier, V., Bellier, O., Miramont, C., Shabanian, E., Fleury, J., Benedetti, L., Guillou, V., ASTER Team, 2016. Weathering-limited hillslope evolution in carbonate landscapes, Earth Planet. Sci. Lett., 446, 10-20.

Godard, V., Hippolyte, J. C., Cushing, E., Espurt, N., Fleury, J., Bellier, O., Ollivier V., ASTER team, 2020. Hillslope denudation and morphologic response to a rock uplift gradient, Earth Surf. Dynam., 8, 221-243, https://doi.org/10.5194/esurf-8-221-2020. 
Gold, P. O., Oskin, M. E., Elliott, A. J., Hinojosa-Corona, A., Taylor, M. H., Kreylos, O., Cowgill, E., 2013. Coseismic slip variation assessed from terrestrial lidar scans of the El Mayor955 Cucapah surface rupture. Earth and Planetary Science Letters, 366, 151-162.

Grellet, B., and Combes, P., 1995. Etude tectonique du chevauchement de Vinon - Analyse de la déformation récente en termes de paléosismicité. Rapport Geoter.

Grützner, C., Fischer, P., Reicherter, K., 2016. Holocene surface ruptures of the Rurrand Fault, Germany - insights from palaeoseismology, remote sensing and shallow physics, Geophys.

960 J. Int., 204, 1662-1677.

Guignard, P., Bellier, O., Chardon, D., 2005. Géométrie et cinématique post-oligocène des failles d'Aix et de la moyenne Durance (Provence, France). Comptes Rendus - Geoscience, 337(3), $375-384$.

Guyonnet-Benaize, C., Lamarche, J., Hollender, F., Viseur, S., Münch, P., Borgomano, J., 965 2015. Three-dimensional structural modeling of an active fault zone based on complex outcrop and subsurface data: The Middle Durance Fault Zone inherited from polyphase Meso-Cenozoic tectonics (southeastern France), Tectonics, 34, https://doi.org/10.1002/2014TC003749.

Harrison, J. C., Jackson, M.P.A., 2014. Exposed evaporite diapirs and minibasins above a canopy in central Sverdrup Basin, Axel Heiberg Island, Arctic Canada, Basin Res., 26(4), 567970596.

Hull, J., 1988. Thickness-displacement relationships for deformation zones. Journal of Structural Geology 10, 431-435. 
Hippolyte, J.C., Brocard, G., Tardy, M., Nicoud, G., Bourlès, D., Braucher, R., Ménard, G., Souffaché, B., 2006. The recent fault scarps of the Western Alps (France): Tectonic surface 975 ruptures or gravitational sackung scarps? A combined mapping, geomorphic, levelling, and ${ }^{10} \mathrm{Be}$ dating approach, Tectonophysics, 418(3-4), 255-276. https://doi.org/10.1016/j.tecto.2006.02.009

Hyppolite, J.C., Bellier, O., Espurt, N., 2012. Quaternary deformation and stress perturbations along the Digne thrust front, Southwestern Alps, C. R. Geoscience, 344, 205-213.

Jannin, S., 2011. Rôle de la tectonique salifère dans la structuration du bassin du Sud-Est (SE 980 de la France): Définition d'un modèle de tectonique salifère d'après l'étude du secteur de Draguignan et comparaison de ce modèle aux structures halocinétiques rencontrées sur l'ensemble du bassin, Mém. d’Ing. Géol., n 476, 97 pp., 50 fig., 4 annexes, Inst. Polytech Lasalle Beauvais, Beauvais, France.

Jomard, H., Cushing, E. M., Palumbo, L., Baize, S., David, C., Chartier, T., 2017. 985 Transposing an active fault database into a seismic hazard fault model for nuclear facilities - Part 1: Building a database of potentially active faults (BDFA) for metropolitan France, Nat. Hazards Earth Syst., 17,1573-1584.

Kergaravat, C., Ribes, C., Legeay, E., Callot, J.P., Kavak, K.S., Ringenbach, J.C., 2016. Minibasins and salt canopy in foreland fold-and-thrust belts: The central Sivas Basin, Turkey. 990 Tectonics, 35(6), 1342-1366. http://doi.org/10.1002/2016TC004186

Kim, Y.S., Peacock, D.C.P., Sanderson, D.J., 2004. Fault damage zones. Journal of Structural Geology 26, 503-517.

Krijgsman, W., Hilgen, F. J., Raf, I., Sierro, F. J., Wilson, D.S., 1999. Chronology, causes and progression of the Messinian salinity crisis. Letters to Nature, 400, 652-655. 
Lacombe, O., Jolivet, L., 2005. Structural and kinematic relationships between Corsica and the Pyrenees-Provence domain at the time of the Pyrenean orogeny. Tectonics, 24(1), TC1003.

Larroque, C., Delouis, B., Godel, B., Nocquet, J.-M., 2009. Active deformation at the southwestern Alps-Ligurian basin junction (France-Italy boundary): Evidence for recent change from compression to extension in the Argentera massif. Tectonophysics, 467(1-4), 22-34.

1000

Lemeille, F., Cushing, M., Cotton, F., Grellet, B., Menillet, F., Audru, J.C., Renardy, F., Fléhoc, C., 1999. Evidence for middle to late Pleistocene faulting within the northern Upper Rhine Graben (Alsace Plain, France), C.R. Acad. Sci. II, 328, 839-846.

Le Pichon, X., Rangin, C., Hamon, Y., Loget, N., Lin, J. Y., Andreani, L., Flotte, N., 2010. Geodynamics of the France Southeast Basin. Bulletin de La Societe Geologique de France, 181(6), $1005 \quad 477-501$.

Lisiecki, L., Raymo, M.E., 2005. Diachronous benthic $\mathrm{d}^{18} \mathrm{O}$ responses during late Pleistocene terminations, Paleoceanography 24, PA3210.

Loke, M.H., 2003. RES2DINV, Rapid 2-D Resistivity and IP Inversion Using the LeastSquare Method. Geotomo Software user's manual, Singapore, 123 p.

Manchuel, K., Traversa, P., Baumont, D., Cara, M., Nayman, E., Durouchoux, C., 2017. The French seismic CATalogue (FCAT-17), Bulletin of Earthquake Engineering.

Masrouhi, A., Bellier, O., Koyi, H., Vila, J., Ghanmi, M., 2013. The evolution of the Lansarine-Baouala salt canopy in the North African Cretaceous passive margin in Tunisia, Geol. Mag., 150(05), 835-861. 

sheets: Gravity-driven deformation of North African Cretaceous passive margin in Tunisia - Bled Dogra case study and nearby salt structures, Journal of African Earth Sciences, 97, 125-142.

Mazzotti, S., Jomard, H., Masson, F., 2020. Processes and deformation rates generating seismicity in metropolitan France and conterminous Western Europe, BSGF, Earth Sci. Bull., 191, 1020 19.

McCalpin, J., Carver, G.A., Goldfinger, C., Hackett, W.R., Jibson, R.W., Nelson, A.R., Obermeier, S.F., Payne, S., Rockwell, T.K., Smith, R.P., Weldon, R.J, 2009. Paleoseismology, Second Edition, International Geophysics Series Vol. 95.

Meghraoui, M., Camelbeeck, T., Vanneste, K., Brondeel, M., Jongmans, D., 2000. Active 1025 faulting and paleoseismology along the Bree fault, lower Rhine graben, Belgium.Journal of Geophysical Research,105(B6), 13809-13841.

Meigs, A., 2013. Active tectonics and the LiDAR revolution. Lithosphere, 5, 226-229.

Mercier, H., 1979. Le Néogène et le Pléistocène inférieur duranciens. Géologie Alpine, t. 55, $111-132$.

Mocochain, L., Audra, P., Clauzon, G., Bellier, O., Bigot, J. Y., Parize, O., Monteil, P., 2009. The effect of river dynamics induced by the Messinian Salinity Crisis on karst landscape and caves: Example of the Lower Ardèche river (mid Rhône valley), Geomorphology, 106(1-2), 46-61.

Molliex S., Bellier, O., Terrier, M., Lamarche, J., Martelet, G., Espurt, N., 2011. Tectonic and sedimentary inheritance on the structural frame- work of Provence (SE France): Importance 1035 of the Salon-Cavaillon fault, Tectonophysics, 501, 1-16. 
Morabito, J., 1967. Evolution tectonique des régions du bas Verdon, Bull. Soc. Géol. Fr. (7), IX, 585-592.

Moragas, M., Vergés, J., Saura, E., Martín-Martín, J.-D., Messager, G., Merino-Tomé, Ó., Suárez-Ruiz, I., Razin, P., Grélaud, C., Malaval, M., Joussiaume, R., Hunt, D.W., 2018. Jurassic 1040 rifting to post-rift subsidence analysis in the Central High Atlas and its relation to salt diapirism, Basin Research, 30, 336-362.

Nocquet, J.M., 2012. Present-day kinematics of the Mediterranean: A comprehensive overview of GPS results, Tectonophysics, 579, 220-242.

Ollivier, V., 2006. Continuités, instabilités et ruptures morphogéniques en Provence depuis 1045 la dernière glaciation. Travertinisation, détritisme et incisions sur le piémont sud du Grand Luberon (Vaucluse, France). Relations avec les changements climatiques et l'anthropisation. Thèse de doctorat de Géographie Physique, Université de Provence U1, 357p.

Ollivier V., 2015. Reading the sequences: A two-step look on Mediterranean Holocene fluvial tufa deposits evolution inferred by climatic and anthropogenic parameters, From archive to 1050 process, Progress in Quaternary archive studies in the Iberian Peninsula, Sevilla, 2015, pp. 32-33.

Pascual, G., 1978. Présence d'une faille à rejeu quaternaire au Cellier des Princes, Courthézon, Vaucluse. Géol. Méditerr., Tome V, 3, 325-326.

Peacock, D., Dimmen, V., Rotevatn, A., Sanderson, D.J., 2017. A broader classification of damage zones, Journal of Structural Geology. http://dx.doi.org/10.1016/j.jsg.2017.08.004.

Prescott J.R., Hutton J.T., 1994. Cosmic ray contributions to dose rates for luminescence and ESR dating: large depths and long-term time variations. Radiat. Meas., 23, 497-500. 
Quenet, G., Baumont, D., Scotti, O., Levret, A., 2004. The 14 August 1708 Manosque, France earthquake : new constraints on the damage area from in-depth historical studies, Annals of Geophysics, 47, n. 2/3.

1060

Rangin, C. L., Pichon, X. A. L. E., Hamon, Y. O., Loget, N. I., Crespy, A. G., 2010. Gravity tectonics in the SE Basin (Provence, France) imaged from seismic reflection data, Bull. Soc. geol. Fr., 181, 6, 503-530.

Reimer, P.J., Bard, E., Bayliss, A., Beck, J.W., Blackwell, P.G., Bronk Ramsey, C., Grootes, P.M., Guilderson, T.P., Haflidason, H., Hajdas, I., Hatt, Ž., C., Heaton, T.J., Hoffmann, D.L., 1065 Hogg, A.G., Hughen, K.A., Kaiser, K.F., Kromer, B., Manning, S.W., Niu, M., Reimer, R.W., Richards, D.A., Scott, E.M., Southon, J.R., Staff, R.A., Turney, C.S.M., van der Plicht, J., 2013. IntCal13 and Marine13 Radiocarbon Age Calibration Curves 0-50,000 Years cal BP. Radiocarbon, $55,4$.

Rhodes, E.J., 2011. Optically Stimulated Luminescence dating of sediments over the past 1070 200,000 years, Annu. Rev. Earth Planet. Sci., 39, 461-488.

Ritz, J., Baize, S., Ferry, M., Larroque, C., Audin, L., Delouis, B., Mathot, E, 2020. Surface rupture and shallow fault reactivation during the $2019 \mathrm{Mw} 4.9$ Le Teil earthquake, France, Commun. Earth Environ., 1, 10. https://doi.org/10.1038/s43247-020-0012-z

Robertson, E.C., 1983. Relationship of fault displacement to gouge and breccia thickness. 1075 American Institute of Mining Engineers Transactions 35, 1426-1432.

Roure, F., Brun, J.-P., Colletta, B., Van Den Driessche, J., 1992. Geometry and kinematics of extensional structures in the alpine foreland basin of southeastern France. Journal of Structural Geology, 14(5), 503-519. 
Rowan, M.G., Vendeville, B.C., 2006. Foldbelts with early salt withdrawal and diapirism: 1080 Physical model and examples from the northern Gulf of Mexico and the Flinders Ranges, Australia, Mar. Pet. Geol., 23(9-10), 871-891.

Sanchez, G., Rolland, Y., Schreiber, D., Giannerini, G., Corsini, M., Lardeaux, J.-M., 2010. The active fault system of SW Alps, Journal of Geodynamics, 49(5), 296-302. https://doi.org/10.1016/j.jog.2009.11.009

Sanderson, D.C.W., Murphy, S., 2010. Using simple portable OSL measurements and laboratory characterisation to help understand complex and heterogeneous sediment sequences for luminescence dating. Quat. Geochronol. 5, 299-305.

Saura, E., Ardèvol I Oro, L., Teixell, A., Vergés, J., 2016. Rising and falling diapirs, shifting depocenters, and flap overturning in the Cretaceous Sopeira and Sant Gervàs subbasins (Ribagorça 1090 Basin, southern Pyrenees). Tectonics, 35(3), 638-662. http://doi.org/10.1002/2015TC004001

Sébrier, M., Ghafiri, A., Bles, J.L., 1997. Paleoseismicity in France : fault trench studies in a region of moderate seismicity. J. Geodynamics, 24, 1-4, 207-217.

Siame, L., Bellier O., Braucher R., Sébrier M., Cushing M., Bourlès D., Hamelin B., Baroux E., De Voogde B., Raisbeck G., Yiou F., 2004. Local erosion rates versus active tectonics: cosmic 1095 ray exposure modelling in Provence (south-east France), Earth Planet. Sci. Lett., 220(3-4), 345364.

Scotti, O., Baumont, D., Quenet, G., Levret, A., 2004. The French macro- seismic database SISFRANCE - objectives, results and perspectives, Ann. geophys., 47(2-3), 571-581. 
Shipton, Z. K., Soden, A. M., Kirkpatrick, J. D., Bright, A. M., Lunn, R. J., 2006. How thick 1100 is a fault? Fault displacement-thickness scaling revisited, Geophysical Monograph Series 170, 193-198.

Tassy, A., 2007. Recent tectonic of the Vinon-sur-Verdon thrust, Master thesis, Université de Provence.

Tassy, A., Mocochain, L., Bellier, O., Braucher, R., Gattacceca, J., Bourlès, D., 2013. 1105 Coupling cosmogenic dating and magnetostratigraphy to constrain the chronological evolution of peri-Mediterranean karsts during the Messinian and the Pliocene: Example of Ardèche Valley, Southern France, Geomorphology, 189, 81-92. http://doi.org/10.1016/j.geomorph.2013.01.019

Tempier, C., 1987. Modèle nouveau de mise en place des structures provençales. - Bull. Soc. géol. Fr., 8, III, 533-540.

1110

Terrier M., 1991. Néotectonique de la Provence occidentale (France) : vers une analyse multicritère des déformations récentes. Applications à la classification des structures sismogènes. Thèse Univ. Provence, Marseille, Doc. BRGM, 207.

Terrier, M., Serrano, O., Hanot, F., 2008. Reassessment of the structural framework of western Provence (France): consequence on the regional seismotectonic model. Geodin. Acta 21, 1115 231-238. https://doi.org/10.3166/ga.21.231-238

Thomas, F., Godard, V., Bellier, O., Shabanian, E., Ollivier, V., Benedetti, L., Rizza, M., Espurt, N., Guillou, V., Hollender, F., Molliex, S., ASTER Team, 2017. Morphological controls on the dynamics of carbonate landscapes under a mediterranean climate, Terra Nova, 29, 3, 173182, http://doi.org/10.1111/ter.12260 
Thomas, F., Godard, V., Bellier, O., Benedetti, L., Ollivier, V., Rizza, M., Guillou, V., Hollender, F., ASTER Team, 2018. Limited influence of climatic gradients on the denudation of a Mediterranean carbonate landscape, Geomorphology, 316, 44-58. https://doi.org/10.1016/j.geomorph.2018.04.014

Thompson Jobe, J. A., Gold, R. D., Briggs, R. W., Williams, R. A., Stephenson, W. J., 1125 Delano, J. E., Shah Anjana, K., Minsley, B., 2020. Evidence for late Quaternary deformation along Crowleys Ridge, New Madrid seismic zone, Tectonics, https://doi.org/10.1029/2019tc005746

Vanneste, K., Meghraoui, M., Camelbeeck, T., 1999. Late Quaternary earthquake-related soft-sediment deformation along the Belgian portion of the Feldbiss Fault, Lower Rhine Graben system, Tectonophysics, 309, 57-79. Jülich, Roer Valley graben, Germany: Coseismic or aseismic faulting history, Geologie En Mijnbouw/Netherlands Journal of Geosciences, 80(3-4), 155-169.

Vella C., Provansal M., 2000. Relative sea-level rise and neotectonic events during the last 6500 year on the southern eastern Rhône delta, France. Marine Geology, 170, 27-39.

Vernet, J.L., 1997. L'homme et la forêt méditerranéenne : de la préhistoire à nos jours, Errance.

Villeger, M., Andrieux, J., 1987. Phases tectoniques post-eocènes et structuration polyphasée du panneau provençal (Alpes externes méridionales), Bull. Soc. géol. France, (8), 3, 1, 147-156. 
Volant P., Berge-Thierry, C., Dervin P., Cushing E. M., Mohammadioun G., Mathieu F., 1140 2000. The southeastern Durance fault permanent network: preliminary results. - J. Seism., 4, 175189.

Walpersdorf, A., Sue, C., Baize, S., Cotte, N., Bascou, P., Beauval, C., Collard, P., Daniel, G., Dyer, R., Grasso, J.-R., Hautecoeur, O., Helmstetter, A., Hok, S., Langlais, M., Menard, G., Mousavi, Z., Ponton, F., Rizza, M., Rolland, L., Souami, D., Thirard, L., Vaudey, P., Voisin, C., 1145 Martinod, J., 2015. Coherence between geodetic and seismic deformation in a context of slow tectonic activity (SW Alps, France), Journal of Geodynamics, 85, 58-65. http://doi.org/10.1016/j.jog.2015.02.001

Wells, D.L., Coppersmith, J., 1994. New empirical relationships among magnitude, rupture length, rupture width, rupture area, and surface dis- placement: Seismological Society of America 1150 Bulletin, v. 84, p. 974-1002.

Zielke, O., Klinger, Y., Arrowsmith, J.R., 2015. Fault slip and earthquake recurrence along strike-slip faults — Contributions of high-resolution geomorphic data. Tectonophysics, 638, 4362. 


\section{Figures captions}

1155

Fig. 1 - Geological map of Provence displaying geology, major faults and mountain ranges (modified from Molliex et al., 2011). Historical (SisFrance, e.g. Scotti et al., 2004) and instrumental (SI-Hex catalogue, data from 1963 to 2009, Cara et al., 2015) seismicity is displayed, as well as the location of various paleoseismological studies (Neopal catalogue).

1160

Fig. 2 - (A) Digital elevation model (DEM) map displaying the area over which high-resolution LiDAR data (30 cm per pixel) were generated for this study. (B) Geological map based on the CEA geological map (Hollender et al., 2014). The north-south black line corresponds to the geological section in figure 4 . The dotted rectangle corresponds to the area displayed in figure 3 and figure 6 . The orange star represents the area where two knickpoints are observed on the south Vinon thrust segment.

Fig. 3 - The Maragrate area in Vinon-sur-Verdon. (A) Geomorphological map of the Maragrate area located near the centre of Vinon-sur-Verdon. The contour interval is $5 \mathrm{~m}$. Black lines depict

1170 the three north-south geological sections (figure 5), and the blue dot shows drill hole BSS002HBZG. (B) Shaded relief LiDAR DEM (30 cm resolution) displaying the Maragrate erosive scarp, indicated by black arrows. (C) Photograph of the Maragrate contact from the roadside (see B inset for picture location) showing the red Miocene clays in abnormal contact with the Pliocene yellow conglomerates. 
Fig. 4 - North-south geological cross-section of the north Vinon thrust segment and the Maragrate fault. See figure $2 \mathrm{~B}$ for section location.

Fig. 5 - North-south geological cross-sections of various scales, centred on the Maragrate fault. See figure $3 \mathrm{~A}$ for location and corresponding numbering.

Fig. 6 - (A) Orthophotograph of the Maragrate area in Vinon-sur-Verdon, depicting the dense vegetation and urbanization. (B) Shaded relief LiDAR DEM with a 30-cm resolution displaying the $\mathrm{N} 120^{\circ}$ orientated Maragrate fault scarp, as highlighted by black arrows, visible under the 1185 vegetation. Same footprint as inset A.

Fig. 7 - (A) Electrical tomography profiles in Vinon-sur-Verdon. Black arrows indicate the morphological scarp of the Maragrate contact. The locations of the six profiles are shown on the LiDAR shaded DEM. Each profile is associated with a letter corresponding to the equivalent inset. VIN01, VIN02, VIN04, VIN06 and VIN07 have an electrode spacing of $2 \mathrm{~m}$ and are $127 \mathrm{~m}$ in length, whereas VIN08 has an electrode spacing of $1 \mathrm{~m}$, resulting in a $63 \mathrm{~m}$-long profile.

Fig. 8 - Map of the Maragrate area showing the extents of trenches T1, T2 and T3. See figure 3 for locations and geological information.

Fig. 9-T1 and T2 paleo-seismological trenches. (A) Geological logs of T1 and T2. Dashed boxes correspond to the pictures on inset B. (B) Interpreted pictures of trenches T1 and T2 displaying various morphological features such as fractures. 
1200 Fig. 10 - Trench T3 was opened along a N50 direction. Both walls of the trench are displayed and are referenced as the south and north walls respectively. Stratigraphic units are described in table 1. A- South wall of the trench. 1: Electrical profile VIN08 (see figure 7). 2: Orthophotomosaic compiled with Agisoft Photoscan software (http://www.agisoft.com) using pictures taken from the trench's south wall. Locations of ${ }^{14} \mathrm{C}$ and OSL samples are depicted. 3: Geological log of 1205 the trench with ${ }^{14} \mathrm{C}$ and OSL sample locations. B- North wall of the trench. 1: Electrical profile VIN08 (see figure 7). 2: Orthophoto-mosaic compiled with Agisoft Photoscan using pictures from the trench's north wall. Locations of ${ }^{14} \mathrm{C}$ and OSL are depicted. 3: Geological log of the trench with ${ }^{14} \mathrm{C}$ and OSL sample locations.

1210 Fig. 11 - (A) Zoom on trench T3 south wall shear zone. (1) Photograph of sheared pebbles located in the shear zone of the trench. (2) Photograph of sigmoid lenses of paleo-soil located in the shear zone of T3. (B) Interpretation and paleoseismic logging.

Fig. 12- (A) South wall of the Vinon-sur-Verdon trench, with ${ }^{14} \mathrm{C}$ and OSL sample ages in cal. BP 1215 and BP respectively. Refer to figure 10 for units name. (B) North wall of the Vinon-sur-Verdon trench, with ${ }^{14} \mathrm{C}$ and OSL sample ages in cal. BP and BP respectively. Refer to figure 10 for unit names.

Fig. 13 - Sediment accumulation and erosion cycles as observed and dated in trench T3 in Vinon1220 sur-Verdon and as measured in other locations in Provence (adapted from Ollivier, 2015). Both the observed sediment accumulation/incision and the averaged sediment accumulation/incision are 
displayed. The various groups of geological units logged in T3 can be correlated with either the observed or averaged sediment accumulation phases in Provence. Colours correspond to the colour scheme on the paleoseismic logs inn figure 10 and figure 12.

1225 


\section{Tables captions}

Table 1 - Sedimentological description of each named unit in trench T3. Results of direct 1230 resistivity measurements performed in the trench are displayed.

Table 2 - Weight percentages of the clay, silt and sand fractions for the 19 grain-size samples tested in this study (locations in figure A). In order to obtain comparable percentages, the total weight of each sample has been brought to 100 grams.

1235

Table 3 - Quartz OSL data and ages measured from trench T3. NC means that Minimum Age Model ages were not calculated for OSL3. $a$. Field moisture; values in brackets indicate complete sample saturation \%. Dose rates calculated using $25 \%$ of the saturated moisture (i.e. $5(30)=30 \mathrm{x}$ $0.25=8$ ). $b$. Analyses obtained using high-resolution gamma spectrometry (high purity Ge

1240 detector). $c$. Includes cosmic doses and attenuation with depth calculated using the methods of Prescott and Hutton (1994). Cosmic doses were between 0.13-0.11 Gy/ka. $d$. Number of replicated equivalent dose $\left(D_{e}\right)$ estimates used to calculate the equivalent dose. Figures in brackets indicate total number of replicated $\mathrm{D}_{\mathrm{e}}$. $e$. Defined as "over-dispersion" of the $\mathrm{D}_{\mathrm{e}}$ values. Values $>30 \%$ are considered to be poorly bleached or mixed sediments. $f$. Dose rate and age for fine-grained 90-125 $1245 \mu \mathrm{m}$ sized quartz. Exponential and linear fits were used.

Table $4-{ }^{14} \mathrm{C}$ samples collected in the Vinon-sur-Verdon trench. Charcoal origin species are indicated. 


\section{Supplementary data}

1250

\section{S1 - Additional geological sections}

Alternative versions of geological sections from figure 4 and figure 5 including Messinian sediments have been produced (figures S1a and S1b). These versions include the hypothesis of the

1255 presence of Messinian sediments that have not been observed at the surface but could be present at depth in the case of the presence of a Messinian canyon in the study area.

\section{S2 - Additional paleoseismic investigations}

\section{1 - Direct resistivity measurements}

In order to test the coherence of geophysical investigations detailed in section 4, direct resistivity measurements were carried out in trench T3 walls for some of the stratigraphic units using an ABEM Terrameter SAS4000 in resistivity mode. The resistivity values measured directly in the unconsolidated/loose units of trench T3 are in agreement with the electrical profiles (in the 60-400

1265 ohm.m range or more) described above (see table 1 for more details). For example, the U9 channel has an electrical resistivity measured at $829 \mathrm{ohm} . \mathrm{m}$, probably corresponding to the high-resistivity patch on profile VIN08 (figure 7 and figure 10). Similarly, the U7 unit has a resistivity of 80 ohm.m and corresponds to a low-resistivity patch on VIN08, thus validating our geophysical measurements and allowing a good correlation between observations resulting from these two 1270 methods. 


\section{2 - Grain-size investigations}

Grain-size measurements were performed to obtain the mass distribution of the different logged units (figure 12) based on sediment grain sizes. 17 samples were collected in the various units of

1275 trench T3 and two additional samples were collected within the Pliocene conglomerate outcrops in the direct vicinity of the trench site (see location in figure 8). One sample was picked up on the roadside southeast of the trench and a second one in an abandoned quarry directly west of the trench site.

All of the sediment samples displayed heterogeneous grain-size distributions with particle

1280 diameters ranging from clays to boulders (figure S2). No single analytical methodology enables to acquire the size distribution for such a broad spectrum. The diameters were obtained from the combination of two techniques: sediment mass distribution for coarser sediments and laser diffraction for clays and silts. The coarser fraction, from sands to boulders, was investigated using sediment mass distribution through humid and dry sieving. The finer, silt and clay, fractions were

1285 distinguished with laser diffraction in order. Each sample was separated into two fractions: a few grams for laser and more than $500 \mathrm{~g}$ for sieving. The laser diffraction samples were sieved to remove the $>63 \mu \mathrm{m}$ fraction, dipped in a deflocculating solution at $3 \%$ in a beaker and aliquoted into the vortex before analysis. The analyses were performed on a Beckman-Coulter LS 13320 laser following the procedure described in the literature (Blott and Pye, 2006; Ghilardi et al., 2012).

1290 This method provides high-resolution size particle spectrum acquisitions for particle diameters ranging from 0.04 to $2000 \mu \mathrm{m}$ using two optical analytic systems. First, from 0.4 to $2000 \mu \mathrm{m}$, a measurement of laser diffraction is performed $(\lambda=750$ or $780 \mathrm{~nm})$ with 126 photodiode detectors grouped in three domains (for high, medium and low angles). Second, particles in the 0.04 to 0.4 $\mu \mathrm{m}$ range are detected by the PIDS (Polarized Intensity Differential Scattering) where light is 
1295 filtered to transmit only three wavelengths $(\lambda=450,600$ and $900 \mathrm{~nm})$ and goes through two perpendicular polarizers.

The measured diameters with the two methods have been combined to estimate the proportions of clays, silts, sands and pebbles. In this study, we only comment on these fractions because field limitations made it impossible to collect quantities of boulder material high enough to be 1300 statistically representative (Bunte and Abt, 2001). The results are compiled in table 2. Uncertainties are usually of $\pm 2 \%$ for the sediment mass initially weighed for the sieving analysis and less than $1 \%$ on the aliquot sub-sampling (Ghilardi et al., 2012). We propose here the reconstruction of a full grain-size distribution for each sample (from $1 \mu \mathrm{m}$ to $90 \mathrm{~mm}$ ). Although this exercise includes uncertainties relative to the two different analyses techniques used, it 1305 provides the relative proportions of the sediment textures.

We note the overall coherence of grain-size investigations in trench T3. Indeed, samples collected within each main unit, differentiated in the log by their colour schemes, display similarities in the distribution of particle diameters (figure S2). The conglomerate unit $(\mathrm{P})$ at the bottom of the trench is very similar to the two Pliocene conglomerate samples from nearby outcrops, with a relatively

1310 high sand fraction and lower clay and silt content, tending to acknowledge the likely Pliocene origin of the P unit in T3. In order to have a dense dataset, unit U1 unit has been sampled four times. The three samples located to the east display a similar grain-size distribution (G-U1-a, GU1-b and G-U1-c) whereas G-U1-d, to the west, has a lower sand content (25\% against 50\%). Moreover, the orange/red sub-unit U1b embedded in the U1 loess has the same silt proportions 1315 (approximately 40\%) as the red clays of unit M, logged as Miocene sediments. The G-U1b sample is also similar to samples G-U1-a, G-U1-b and G-U1-c, indicating a probable reworking of the U1 and $\mathrm{M}$ units. This could explain the orange fabric observed in the trench within U1b. The G-U4, 
G-U5 and G-U6 samples from the channel units in green on the log (figure 12) have comparable grain-size distributions, even though G-U5 is richer in silts and poorer in sands. However, fine-

1320 grained unit sample G-U7 is richer in clays and silts, supporting the channel hypothesis. The most recent channel units in blue on the log (G-U2, G-U3, GU10-a and G-U10-b) have similar clay content but vary in sand and silt content.

\section{S3 - Additional geochronological information}

1325

\section{1 - OSL investigations}

Central Age Model (CAM) ages and Minimum Age Model (MAM) ages were calculated for two OSL samples (MA16-OSL1 and MA16-OSL2), resulting in minor age differences (see Galbraith and Roberts, 2012 for more information). For MA16-OSL1, we only exclude one of the equivalent 1330 dose $\left(D_{e}\right)$ at $\sim 140 \mathrm{~Gy}$, which we interpret as related to not well-bleached grains. For MA16-OLS2, all aliquots were used to determine the final $\mathrm{D}_{\mathrm{e}}$. For MA16-OSL3, 18 aliquots were analyzed. The distribution of the $D_{e}$ shows three grain populations around $30 \mathrm{~Gy}, 210 \mathrm{~Gy}$ and $350 \mathrm{~Gy}$, which resulted in a $41 \%$ scattering (figure S3 and table 3). The first population of grains presents low $D_{e}$ values similar to those observed in samples MA16-OSL1 ( 34.0Gy) and MA16-OSL2 ( 30.6 Gy),

1335 collected from unit U1 located stratigraphically above the conglomerates. We suspect that these $\mathrm{D}_{\mathrm{e}}$ may correspond to intrusive grains mixed into the original deposit $(\mathrm{P})$ through some postdepositional processes. We therefore exclude them from our final $\mathrm{D}_{\mathrm{e}}$ determination, resulting in a scattering of only $12 \%$. In addition, we observed possible saturation in the luminescence signal of the decay curves for a few aliquots. Given the fact that it is impossible to sort out the degree of saturation, we consider the age of $195.9 \pm 30.8 \mathrm{ka}$ as a minimum age. 


\section{2 - Charcoal analysis under the microscope}

Charcoal samples were analyzed under a microscope to determine their source vegetation species (table 4) and investigate the evolution of ground occupation in the study area since the beginning

1345 of the Holocene. Past landscapes reconstructed by charcoal identification in different stratigraphic layers of the T3 trench are substantially the same as those observed today. They belong to deciduous and evergreen forests. The degraded samples C43 and C50 were difficult to identify due to their poor state of conservation. The other samples revealed forest trees (deciduous oak, evergreen oak) and understorey or open environment shrubs (steep slopes, clearings) (Cistus,

1350 Buxus, Cotinus, Acer). Cistus (Cistus) and boxwood (Buxus) extensions are strongly correlated to human activities such as fire or grazing. In conclusion, our charcoal analysis is insufficient to reveal a change in vegetation cover through time. The landscape seems to remain characteristic of Mediterranean ecosystems from the bottom to the summit (Vernet, 1997), indicating that the sediment incision and accumulation cycles deduced from our observations and dating did not 1355 impact the surrounding vegetation during the last several millennia.

Fig. S1a - North-south geological cross-section of the north Vinon thrust segment and the 1360 Maragrate fault including possible Messinian sediments from the Durance-Verdon hydrographic system. See figure 2B for section location. 
Fig. S1b - North-south geological sections of various scales, centred on the Maragrate fault including possible Messinian sediments from the Durance-Verdon hydrographic system. See 1365 figure $3 \mathrm{~A}$ for location and corresponding numbering.

Fig. S2 - Ternary diagram of the grain-size distribution of sediment samples collected on the southern wall of trench T3. The respective weight percentages of the clay, silt and sand fractions are displayed. Sample colours correspond to the colour scheme of their origin unit as displayed in

1370 figure 10. The location of each sample in the trench is visible on the bottom log. The locations of the Pliocene quarry and road grain-size samples are depicted in figure 8. For more information on the grain-size fraction percentages, see table 2 .

Fig. S3 - Dose (Gy) against Lx/Tx parameter and dose (Gy) probability density for MA16-OSL1, 1375 MA16-OSL2 and MA16-OSL3. 


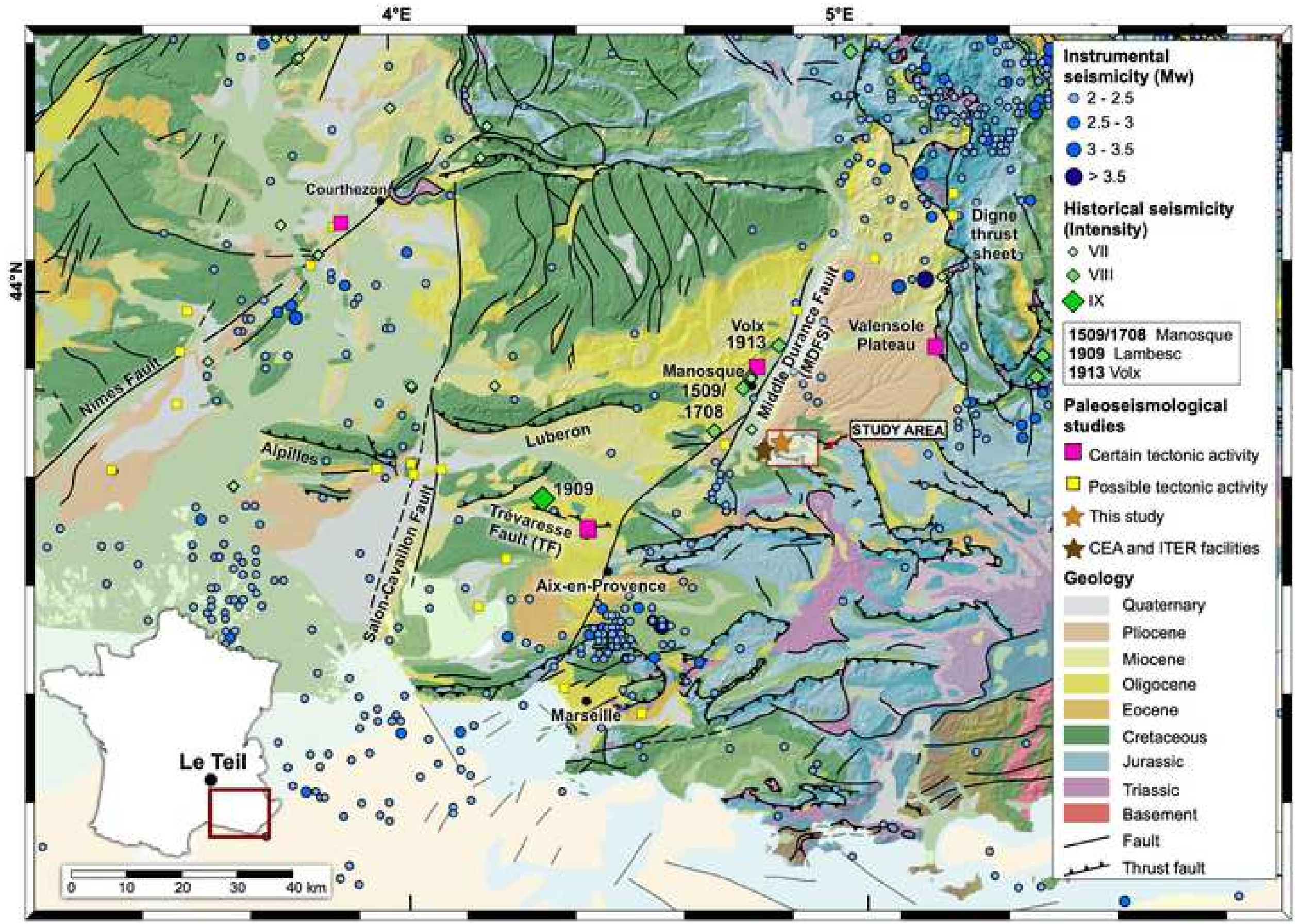



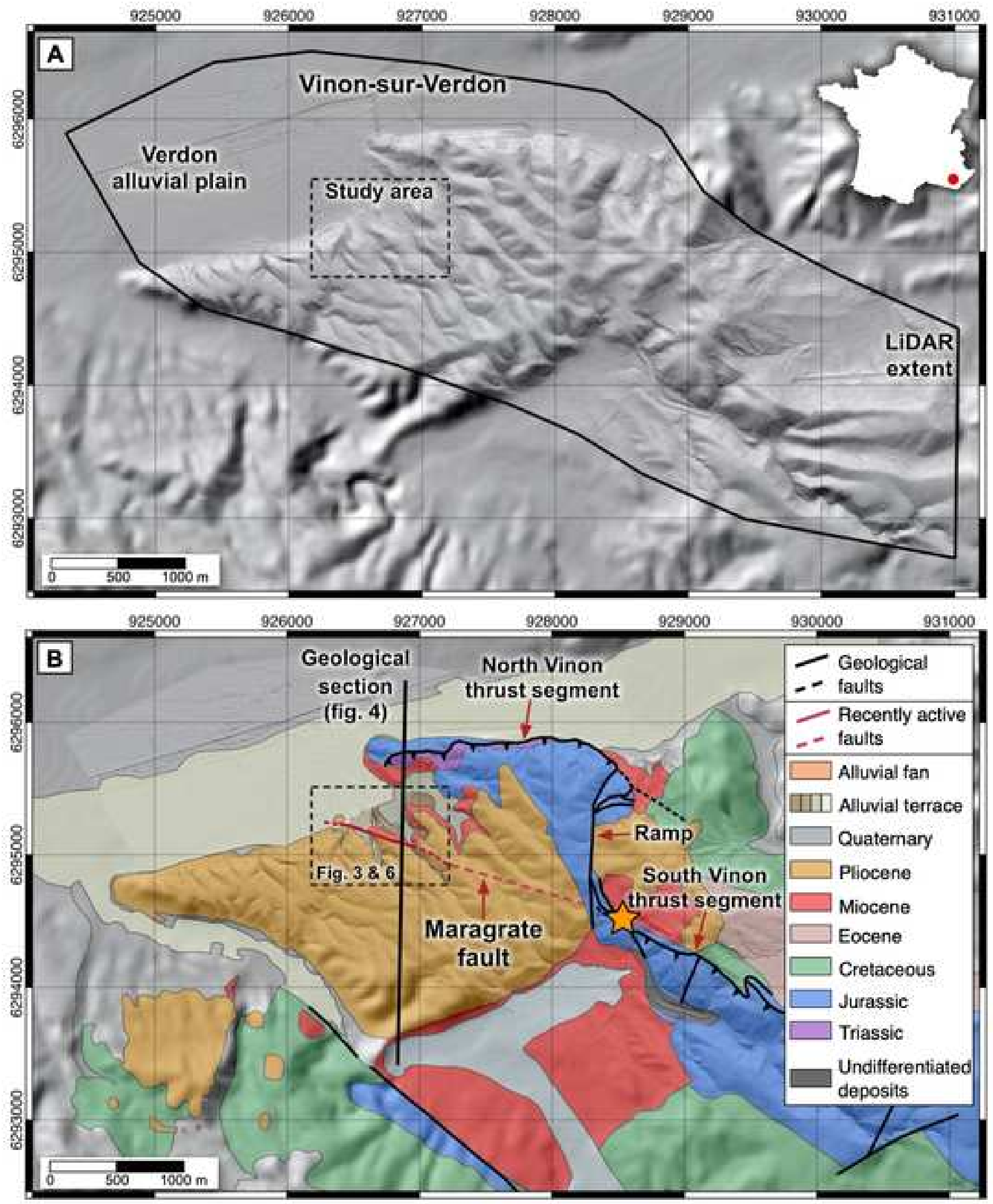

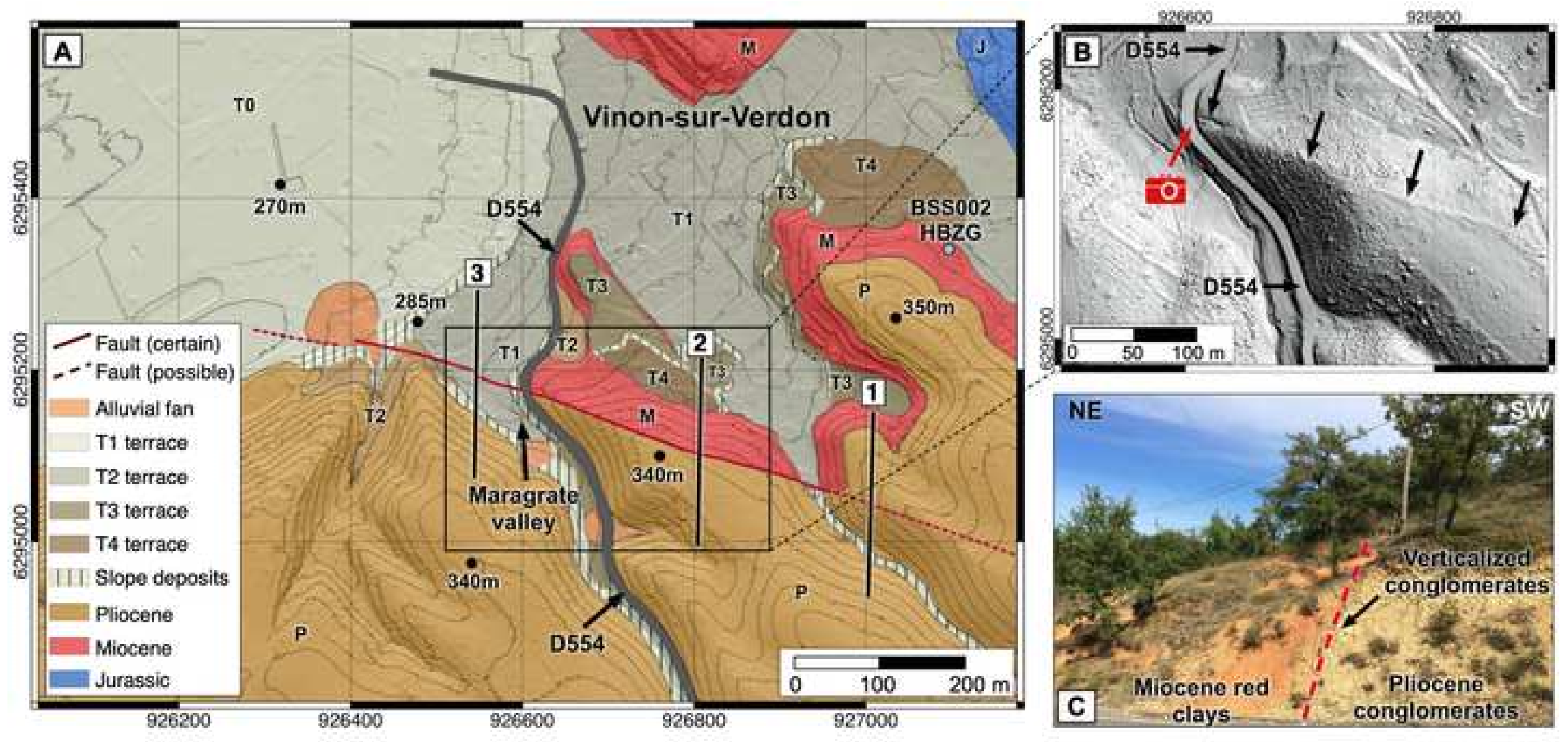


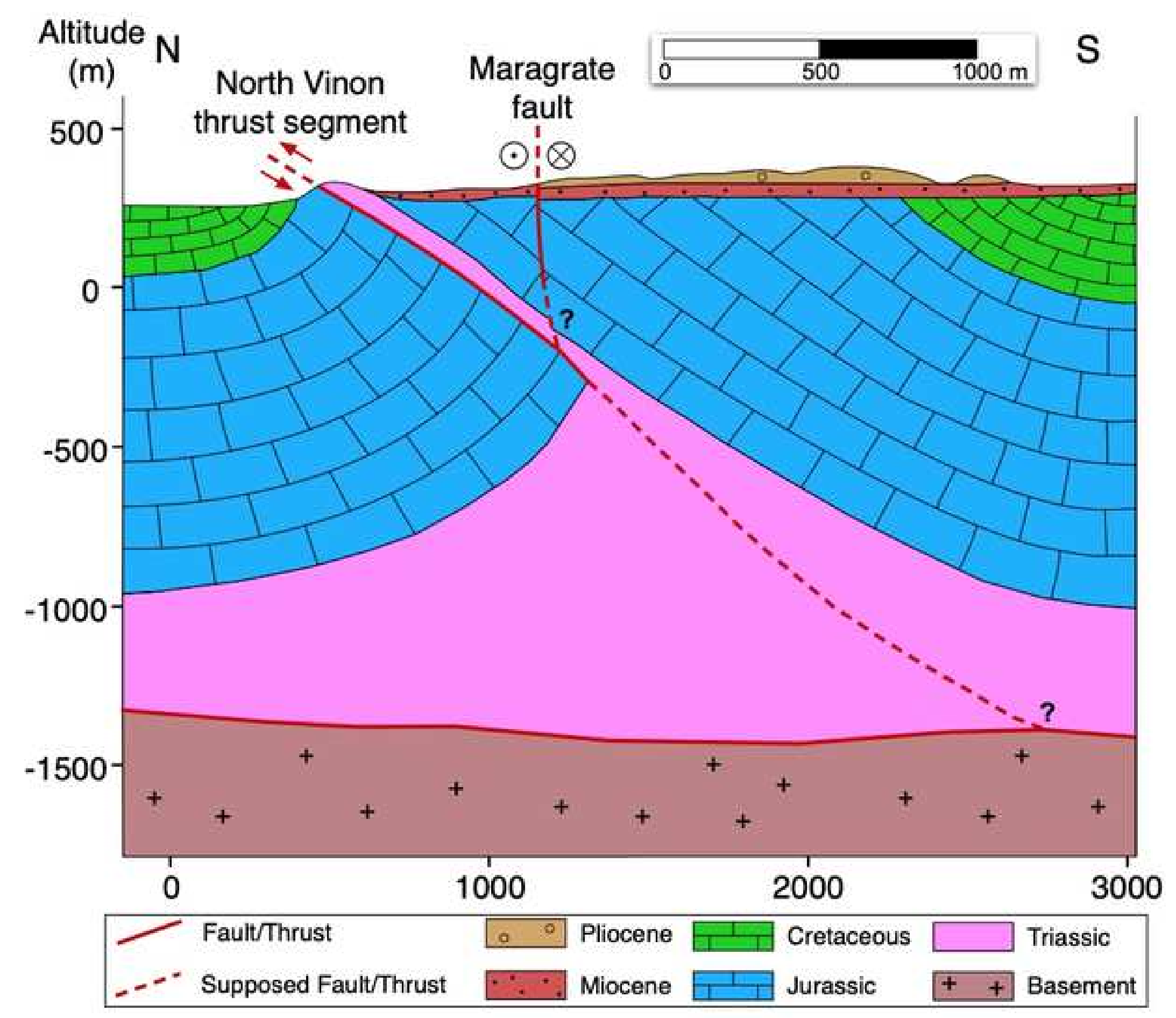



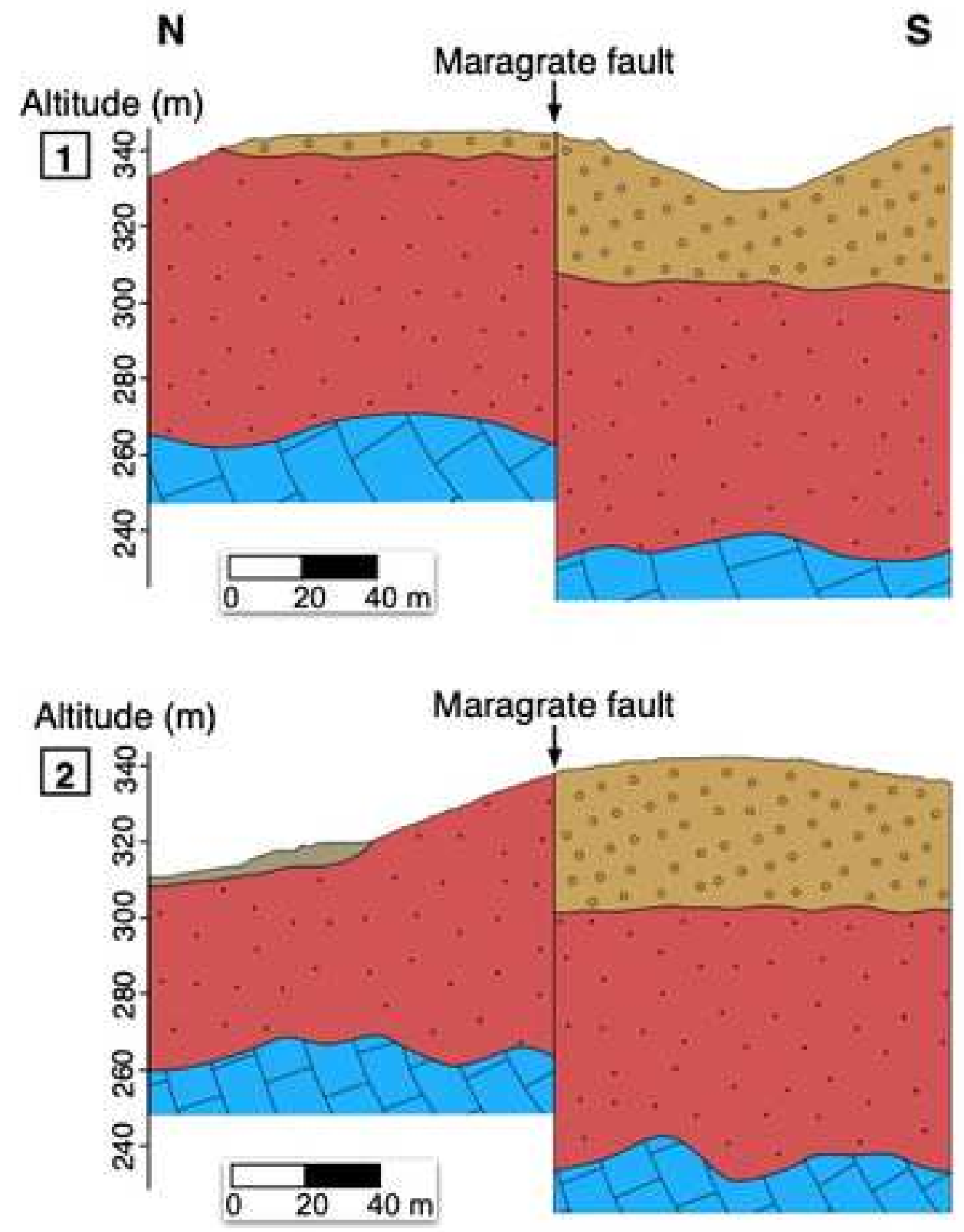

Altitude (m)

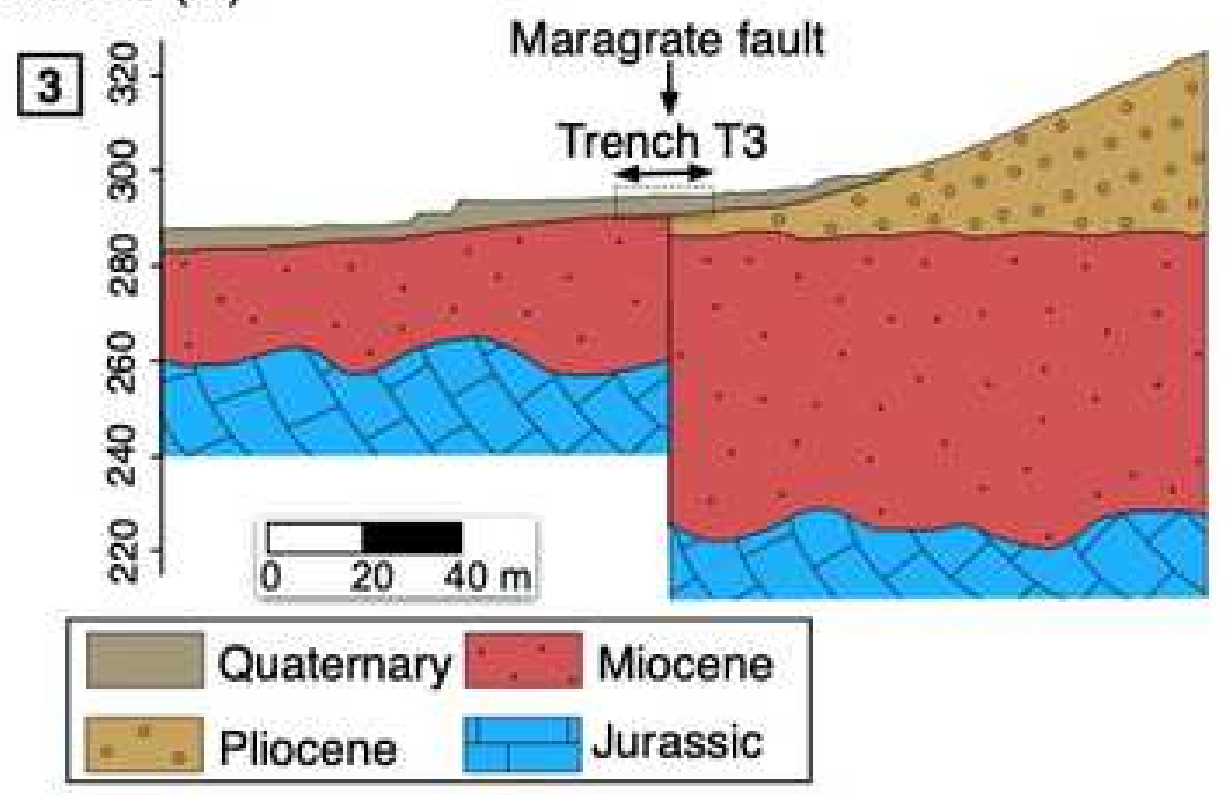



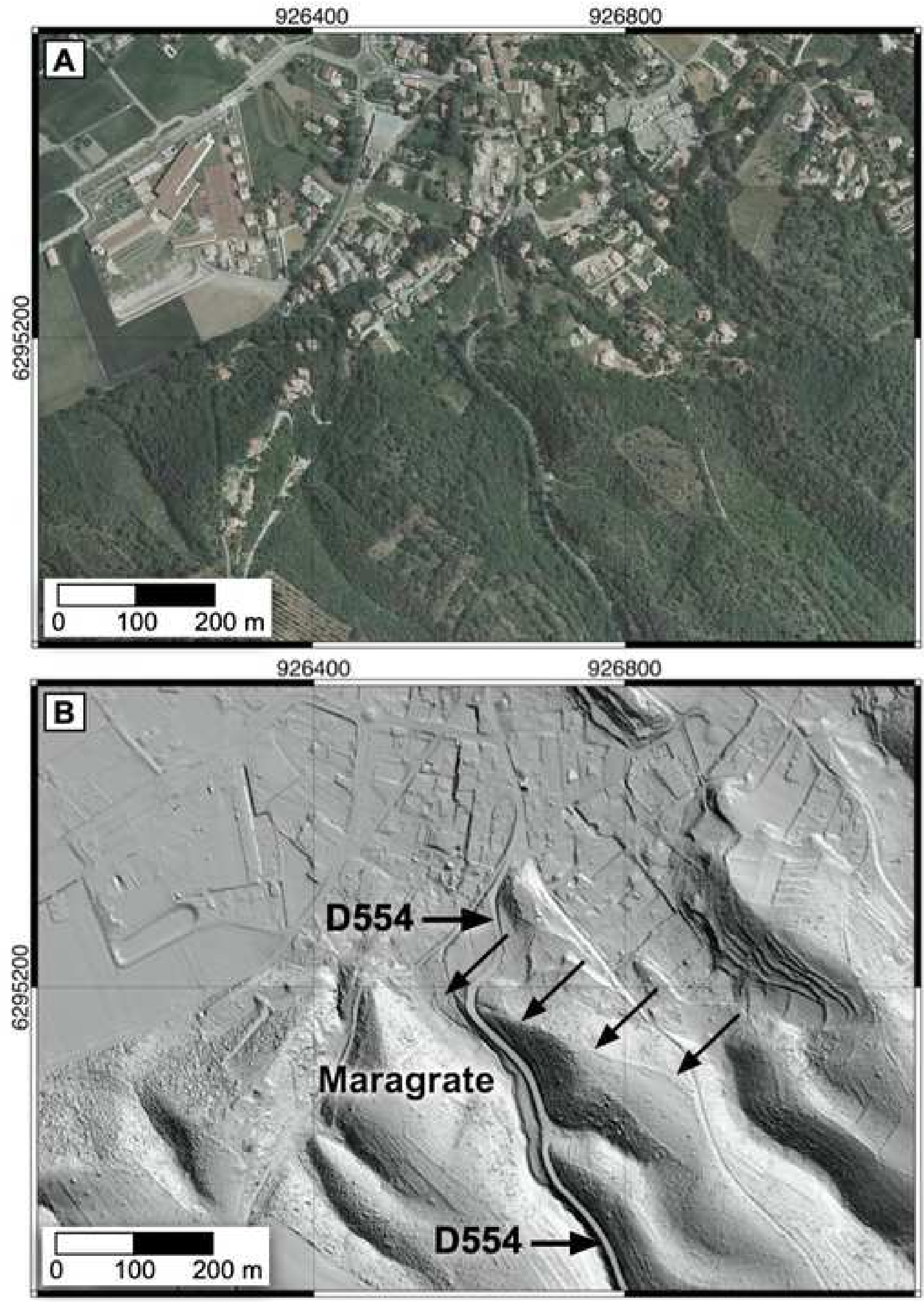


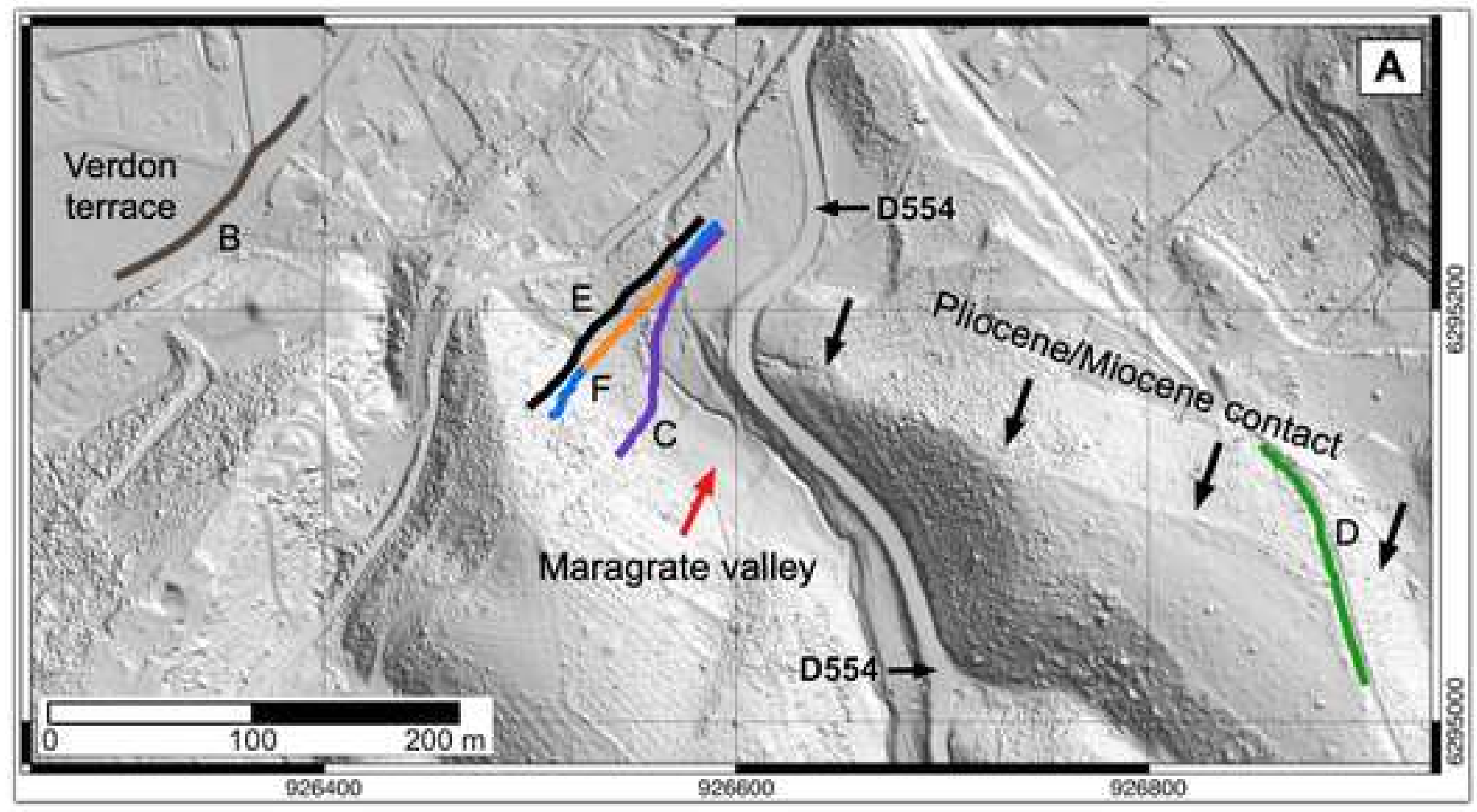

\section{Electric tomography profiles: $>$ VIN01 $>$ VIN02 $>$ VIN04 $>$ VIN06 $>$ VIN07 $>$ VIN08}

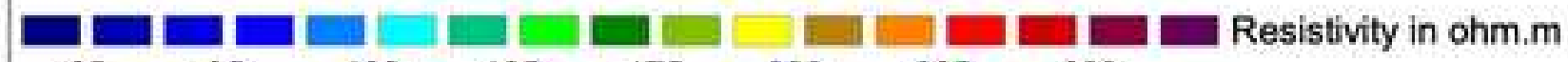
$\begin{array}{llllllll}65 & 85 & 100 & 135 & 175 & 220 & 285 & 360\end{array}$
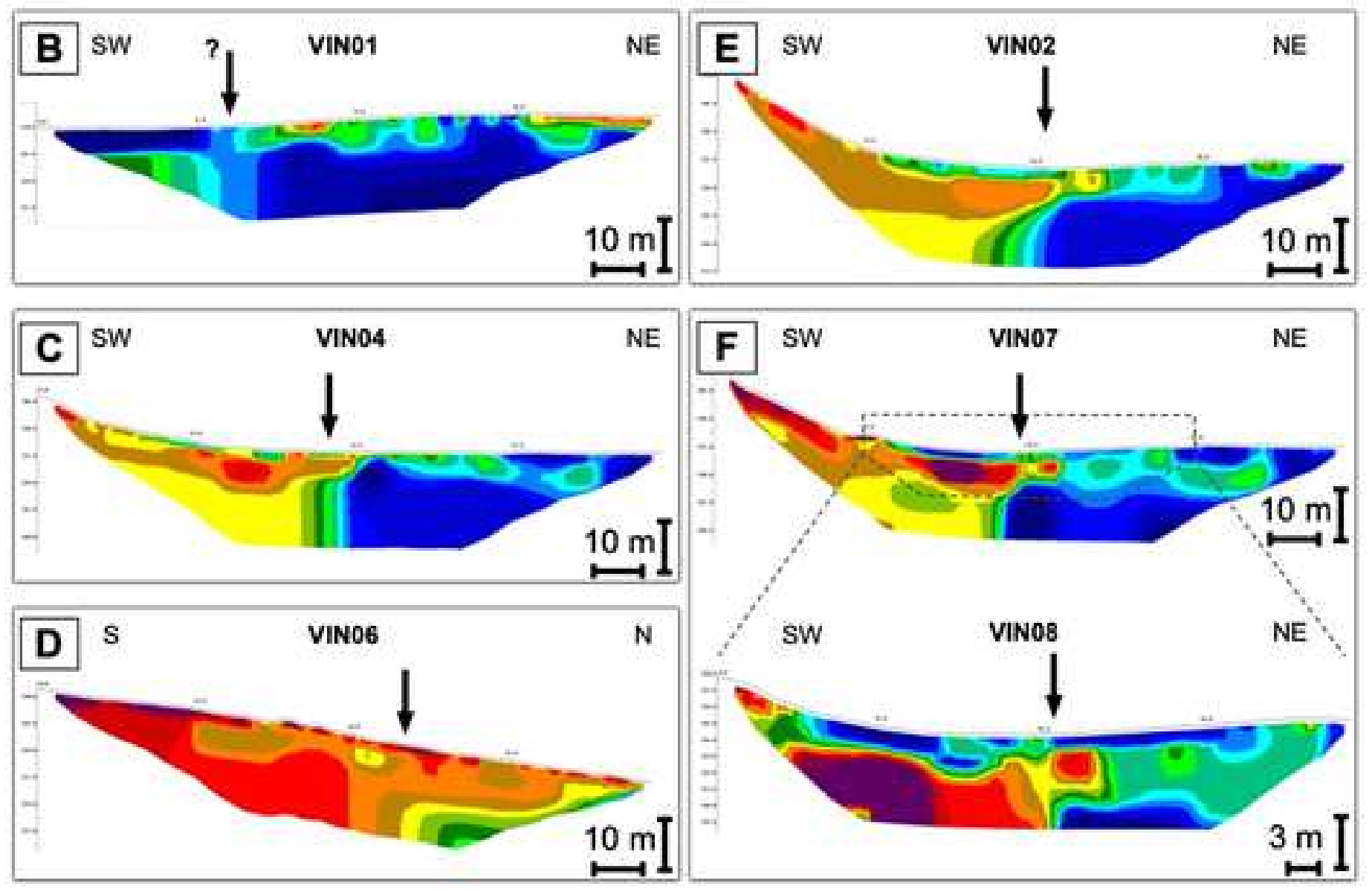


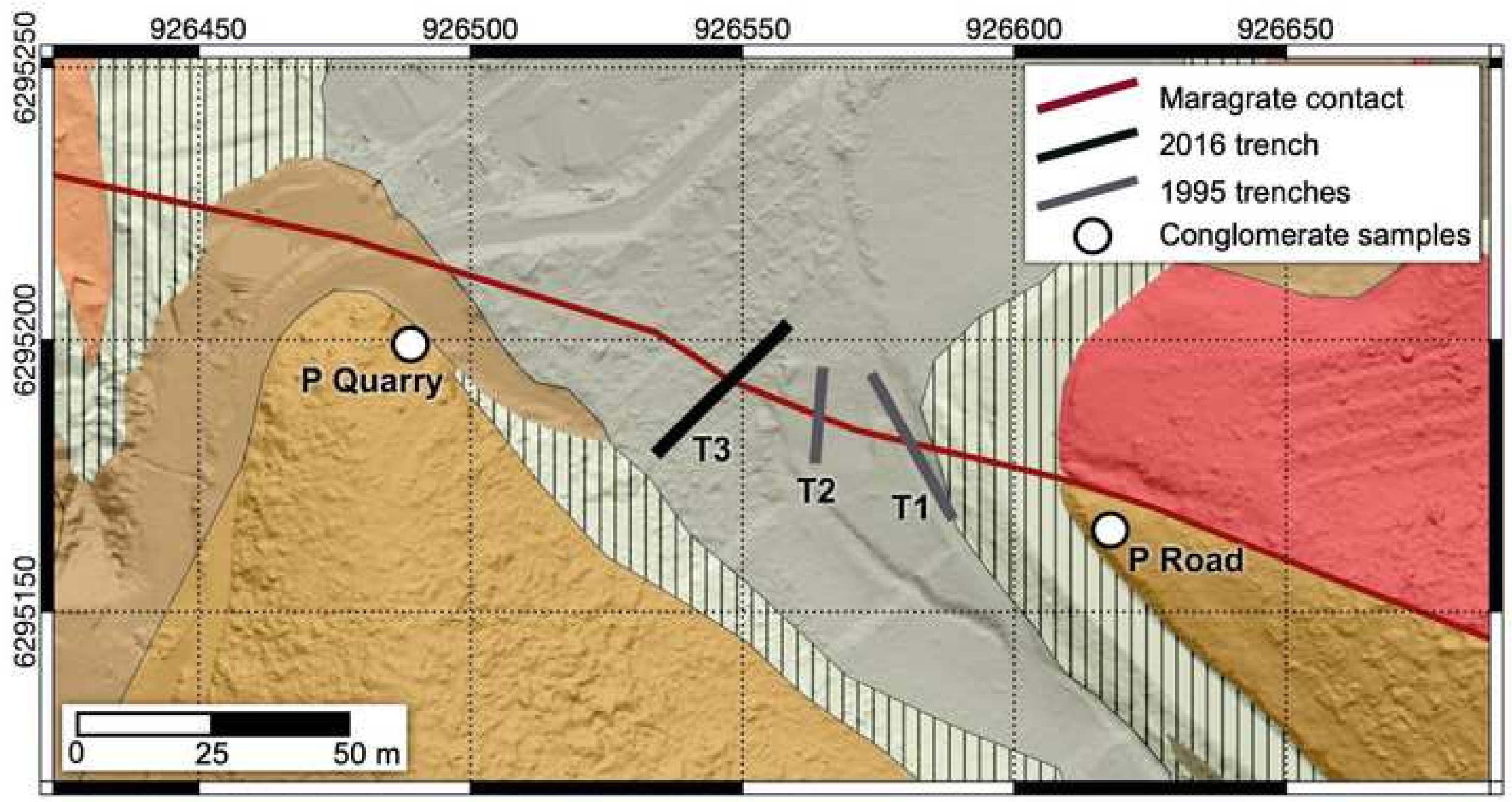



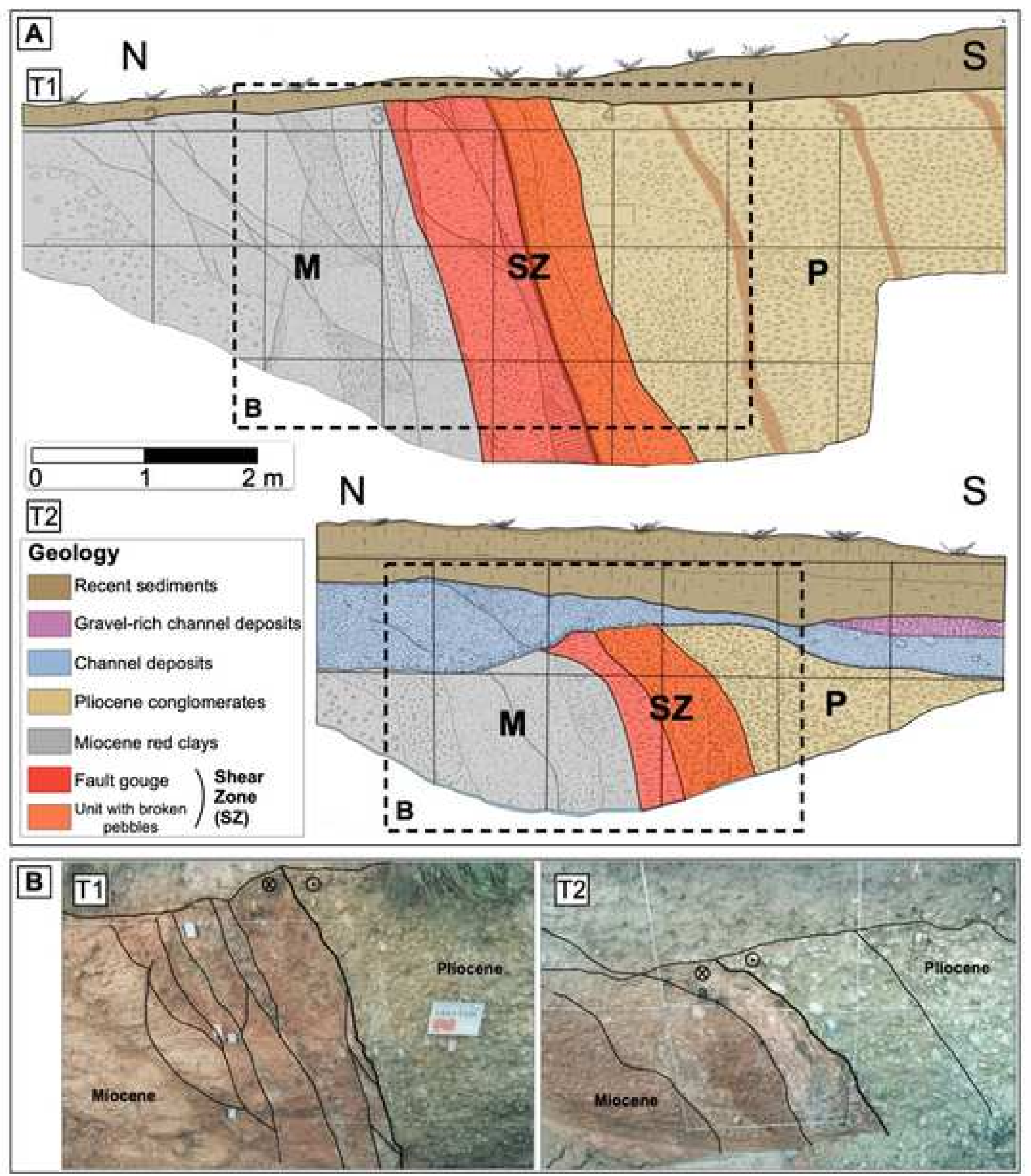


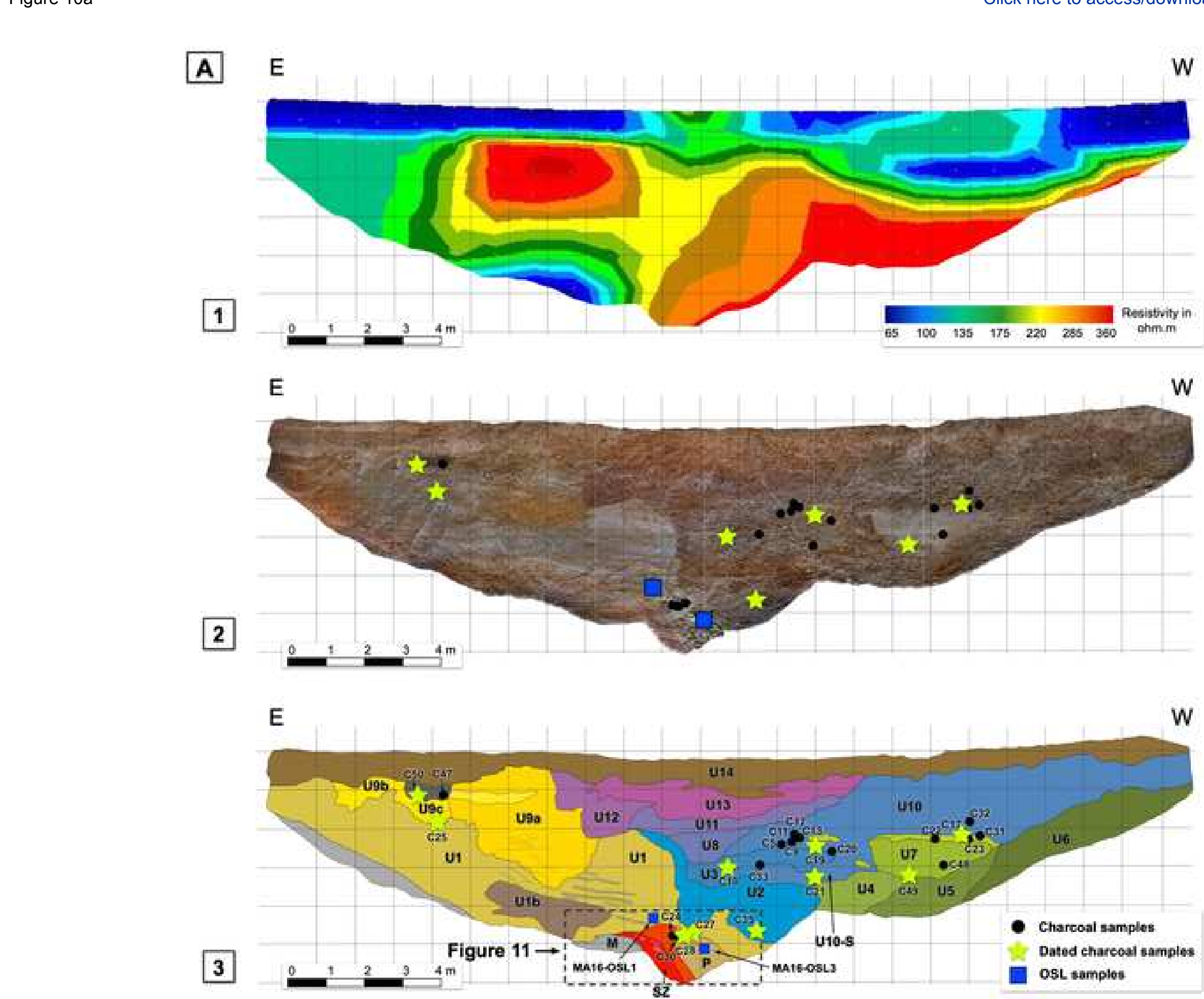

2
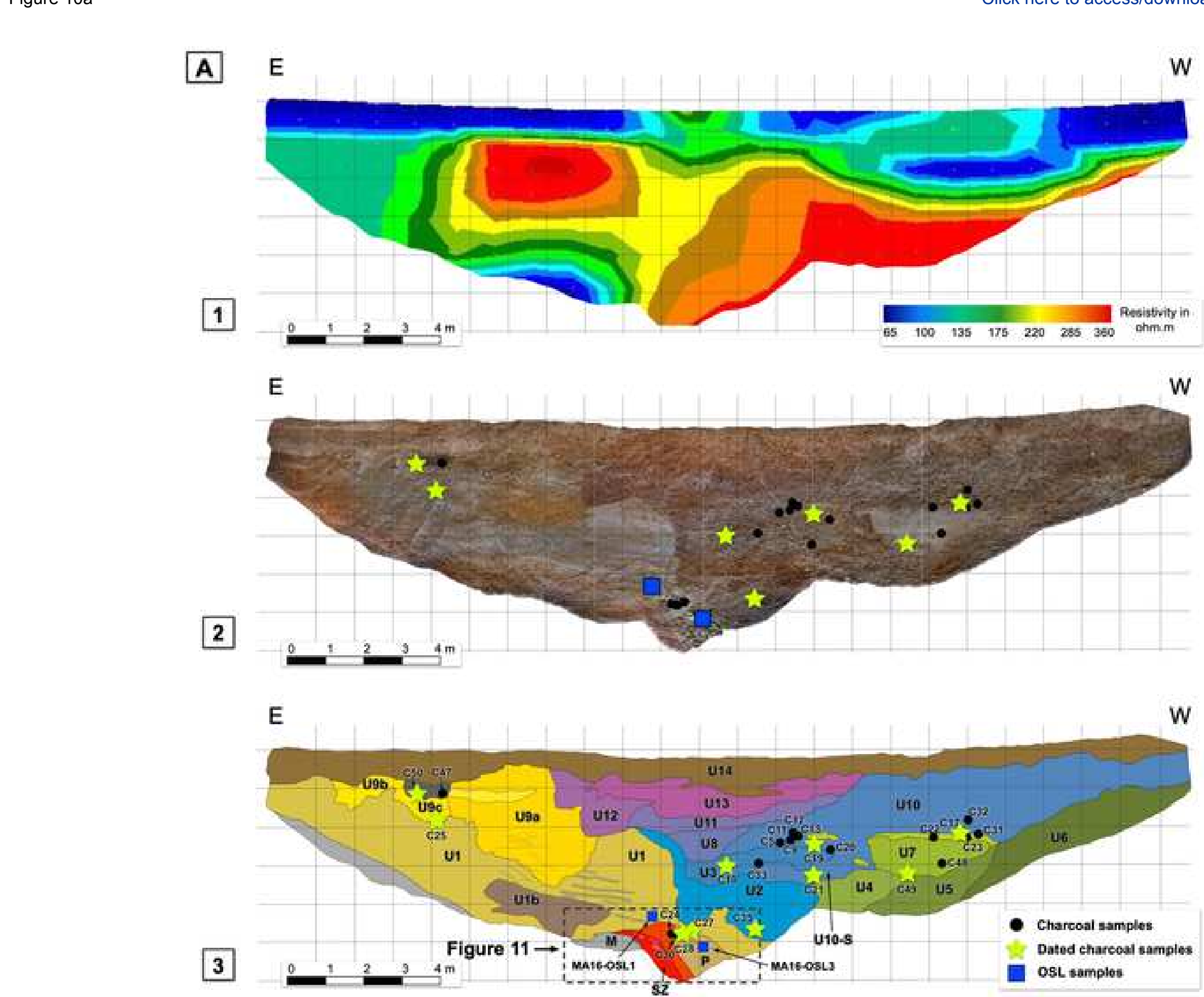

E
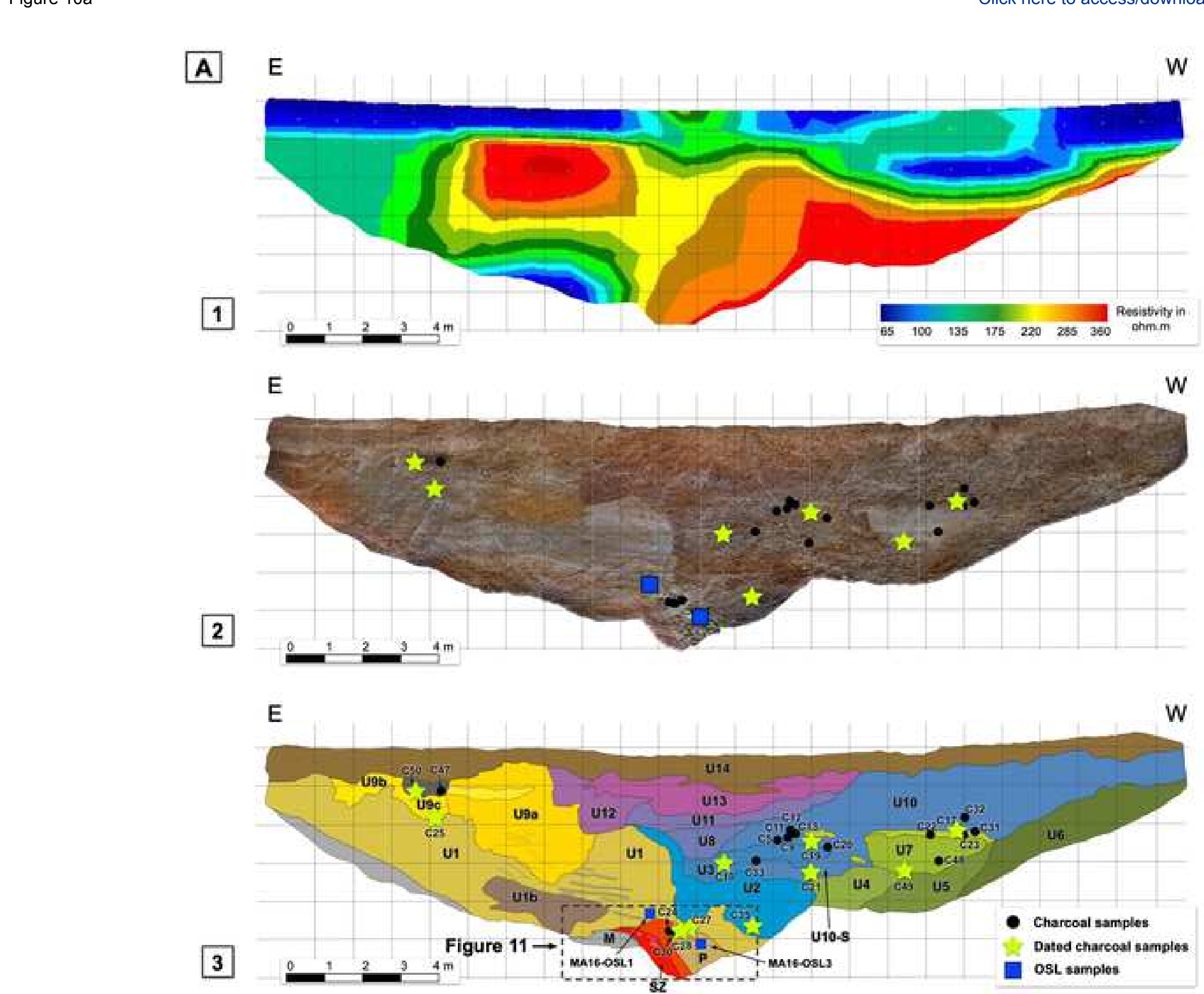

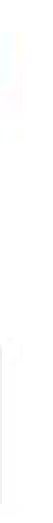



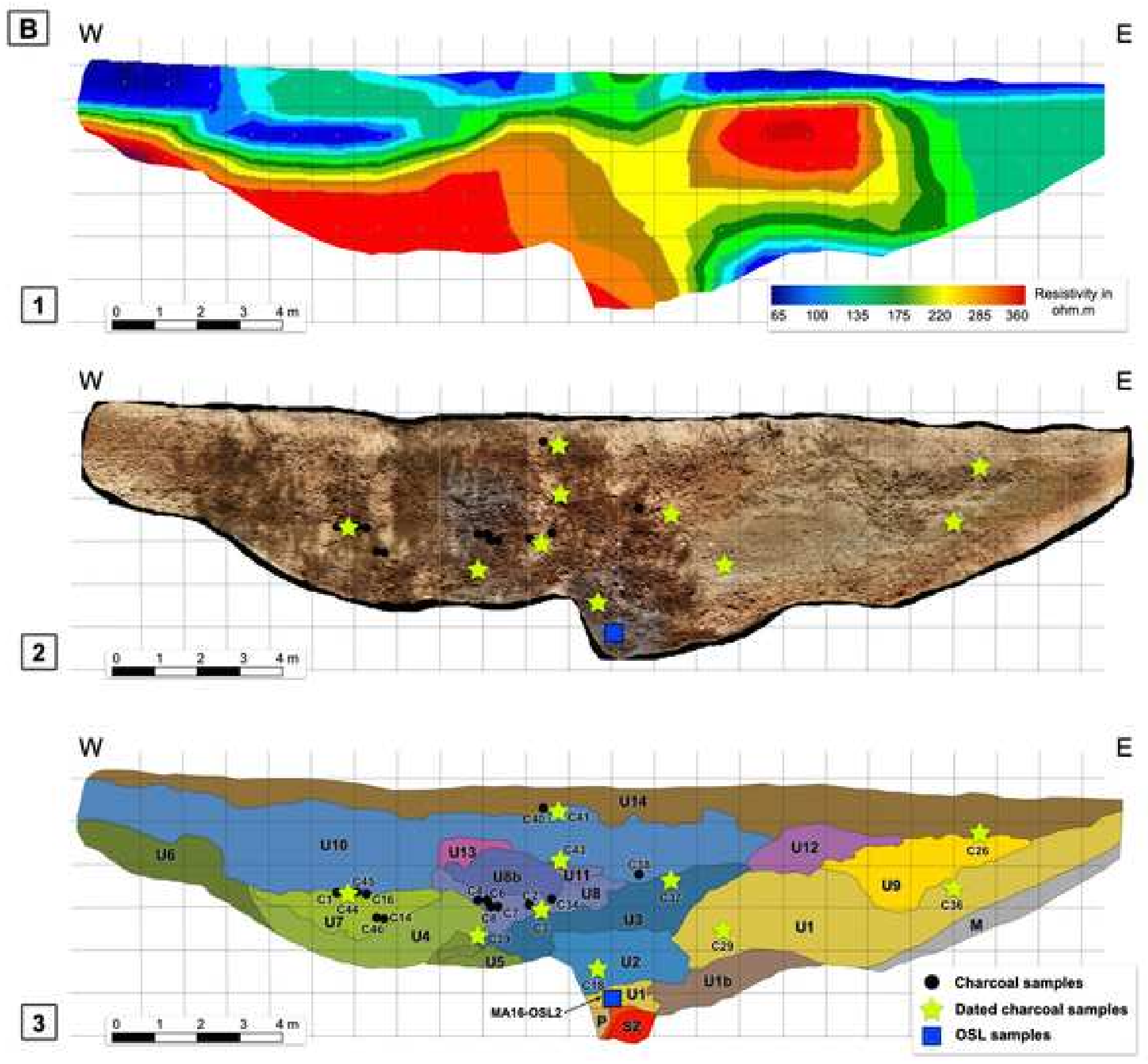

E

E

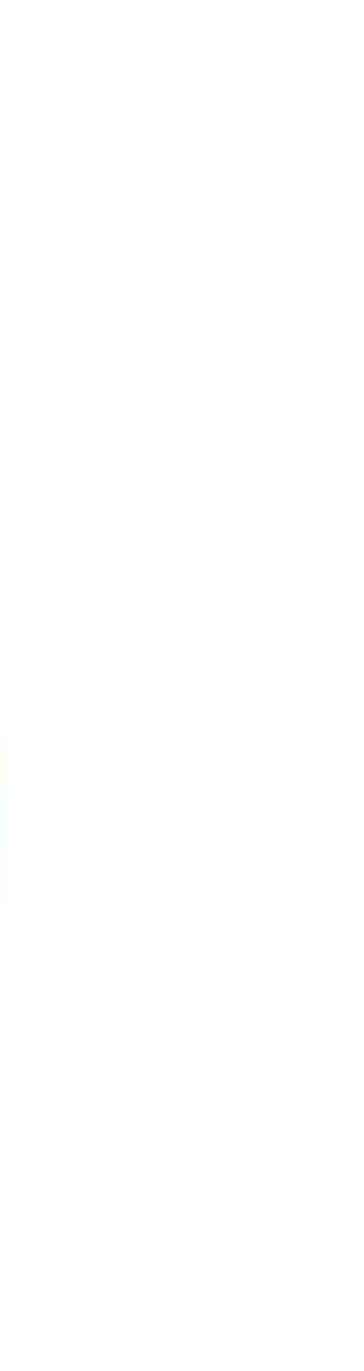



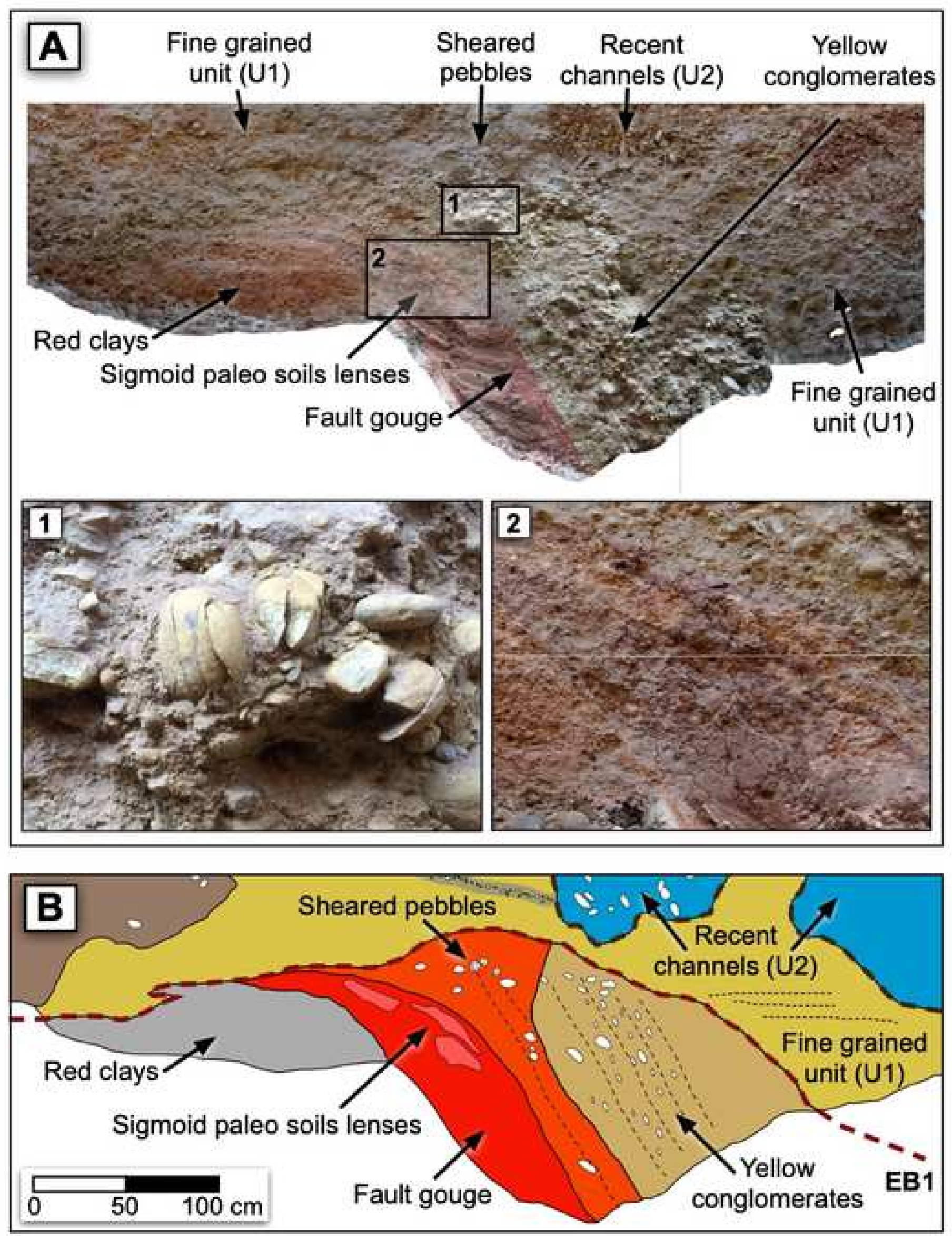


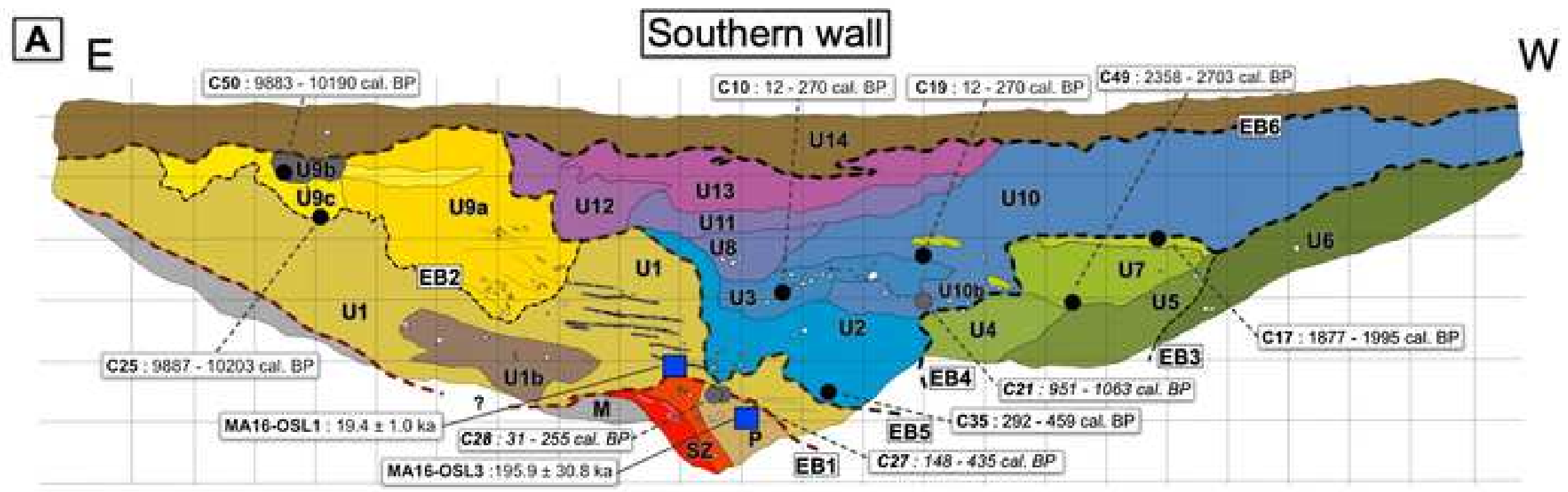

\section{B W}

Northern wall

E

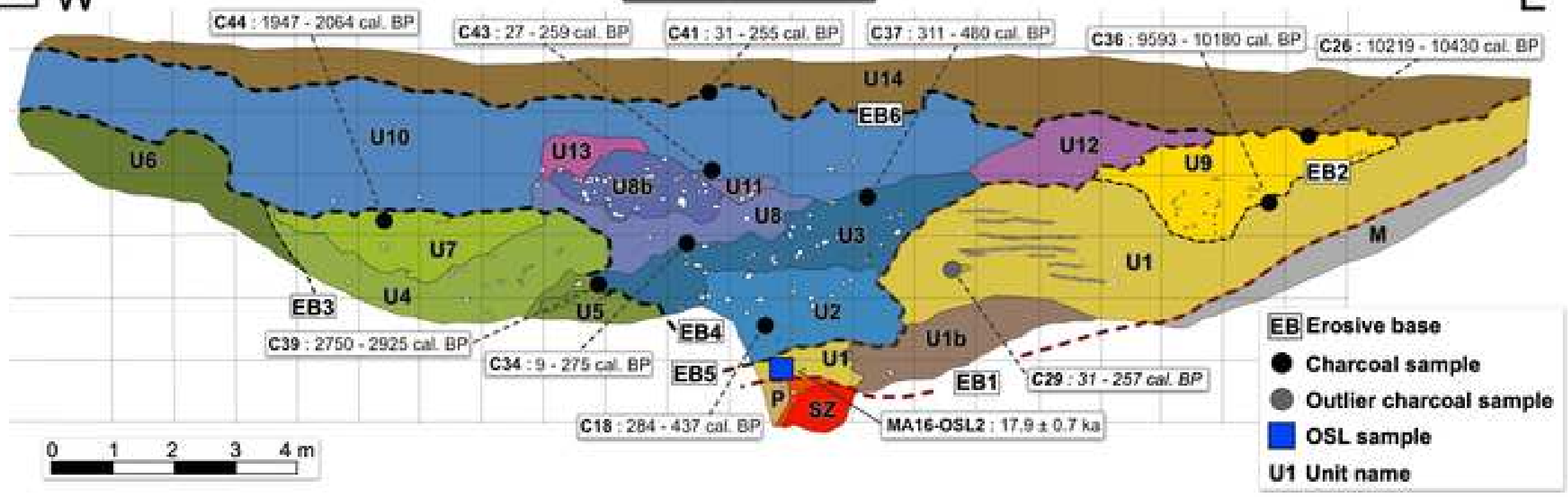



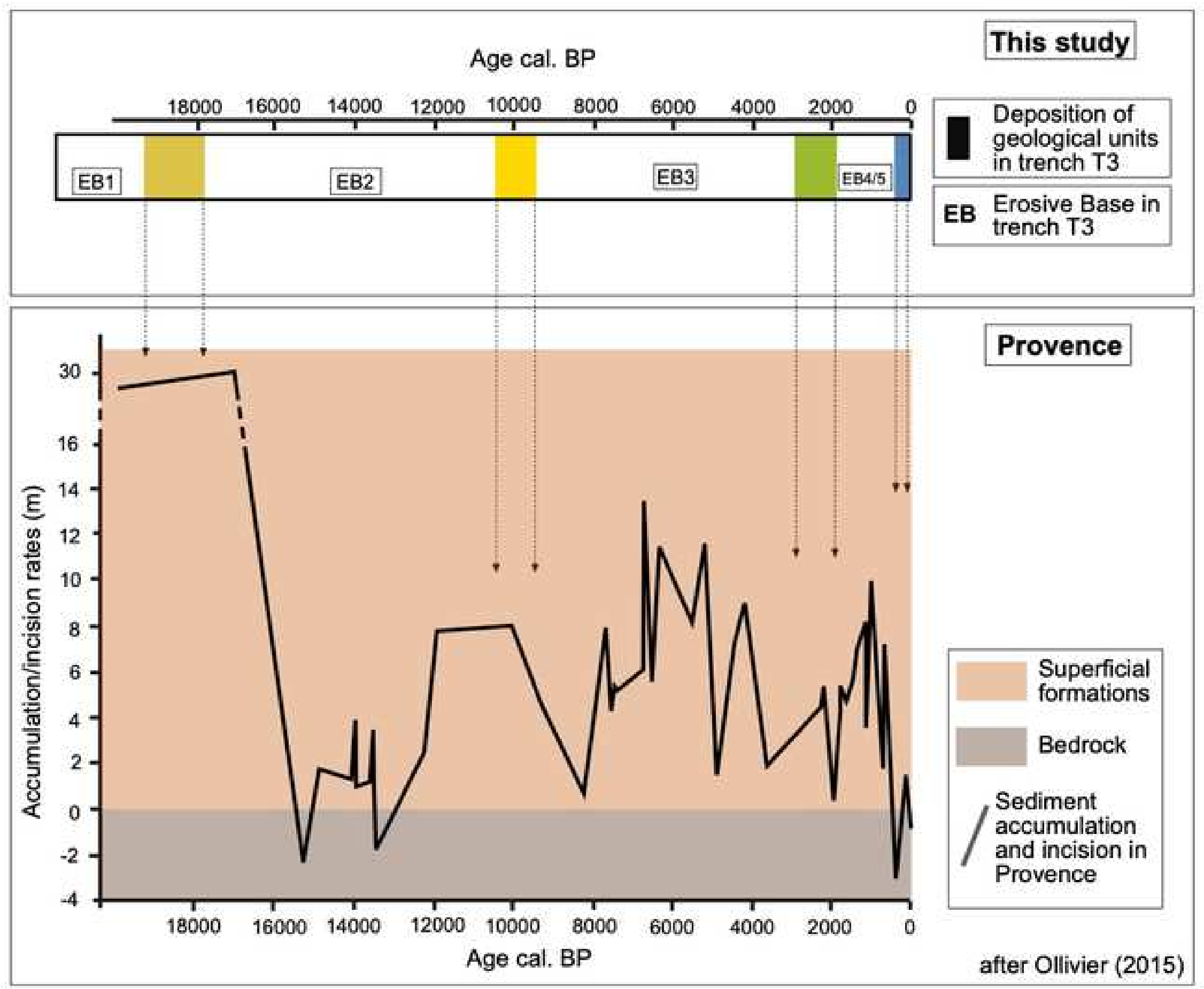


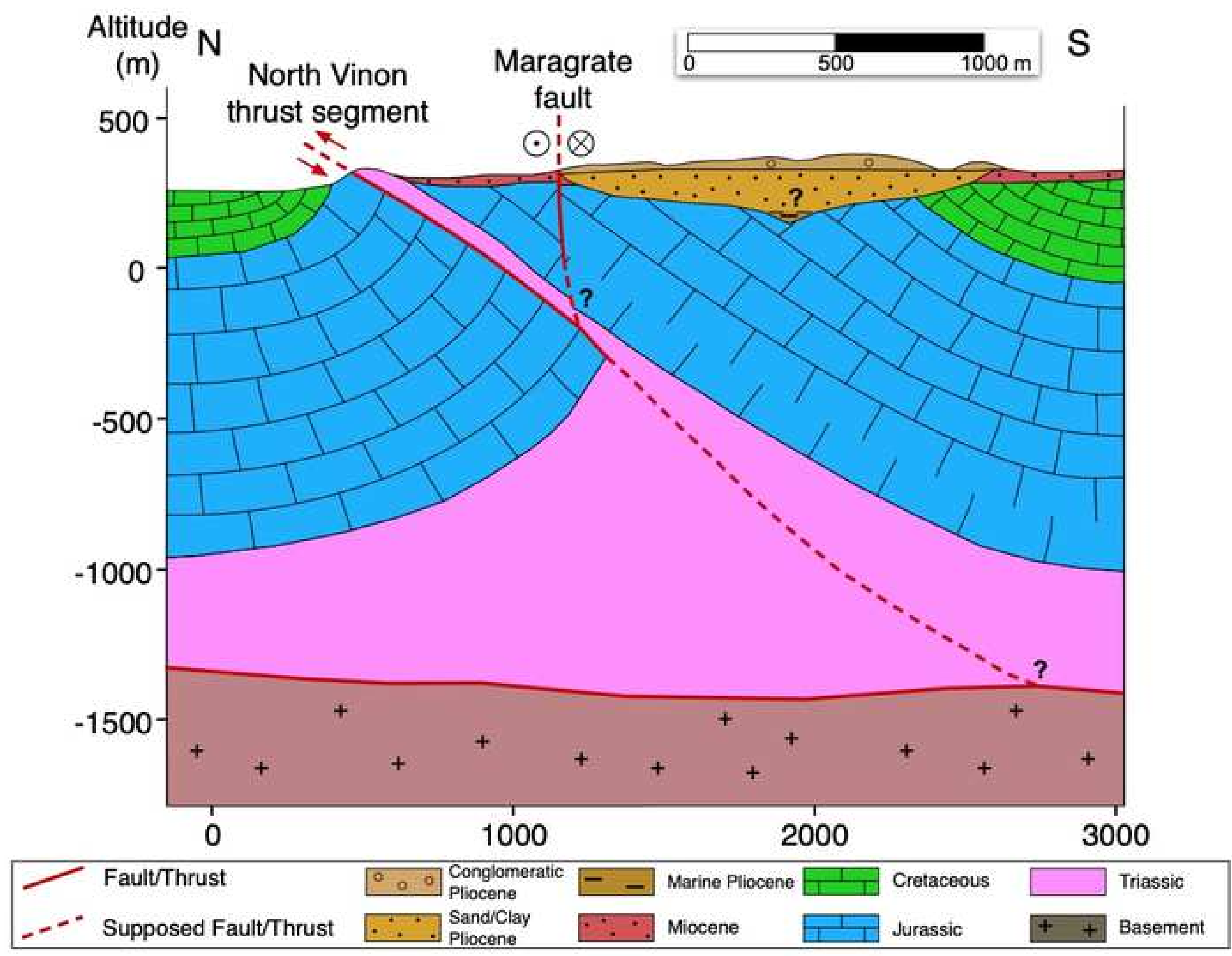



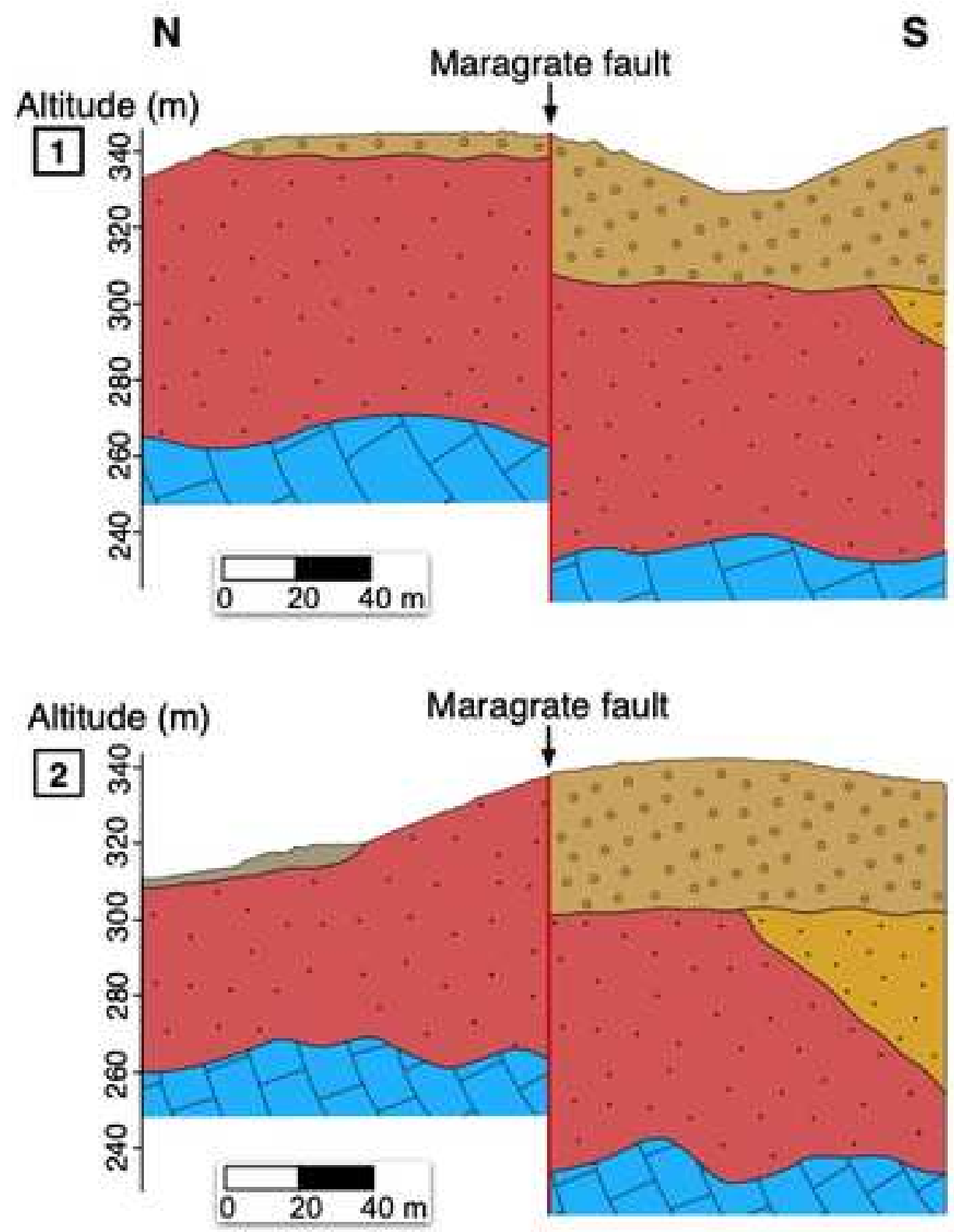

Altitude (m)

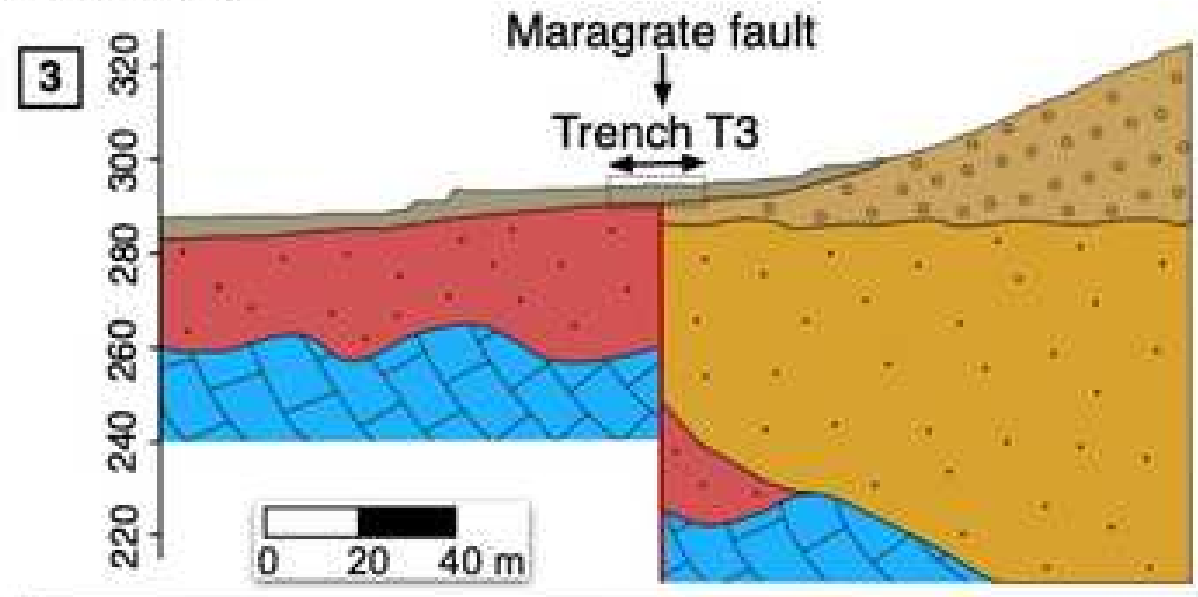

\begin{tabular}{|l|l|l|}
\hline $\begin{array}{l}\text { Quaternary } \\
\text { Pliocene } \\
\text { (Valensole II) }\end{array}$ & $\begin{array}{l}\text { Continental } \\
\text { Pliocene }\end{array}$ \\
\hline
\end{tabular}



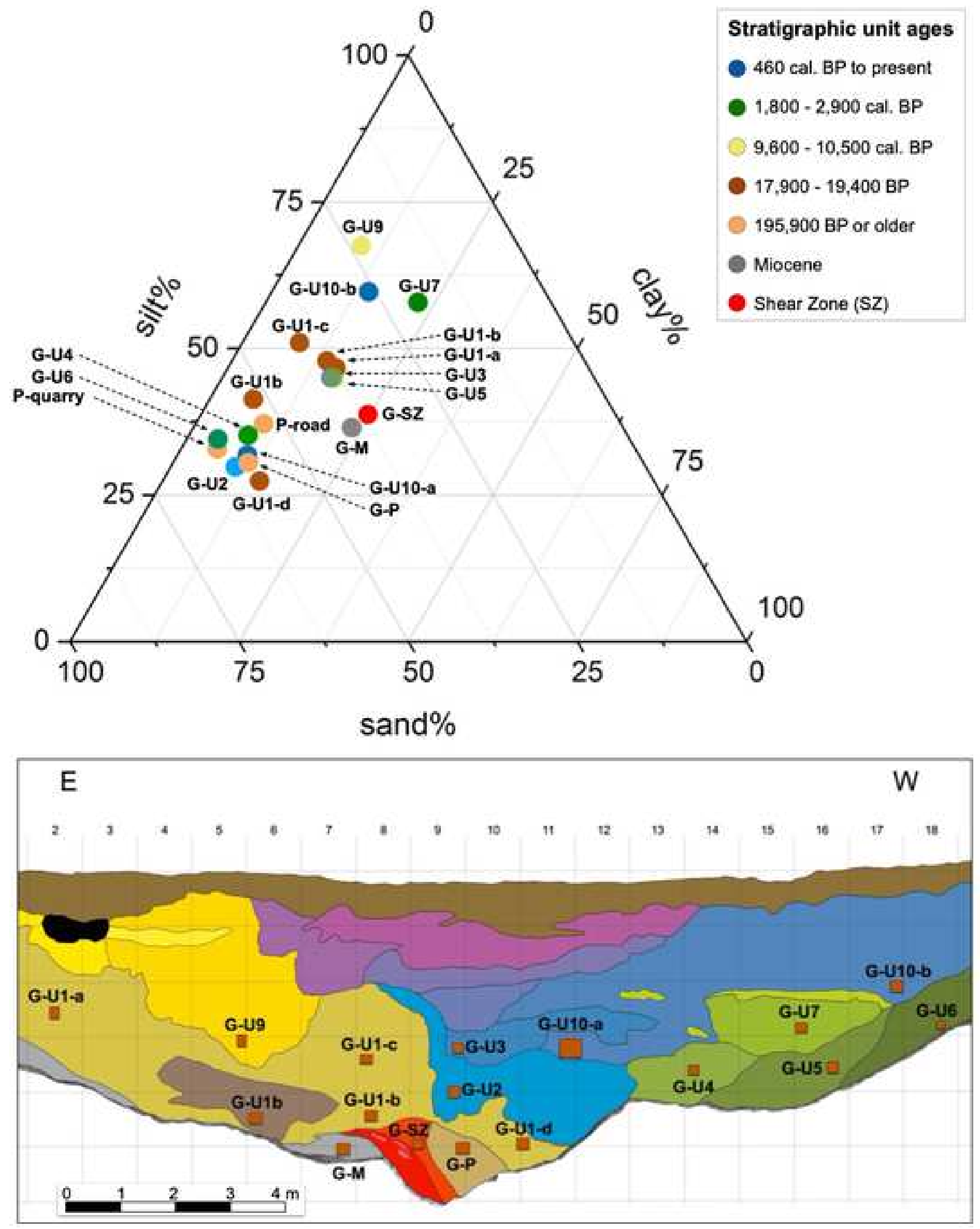


\section{MA16-OSL1}
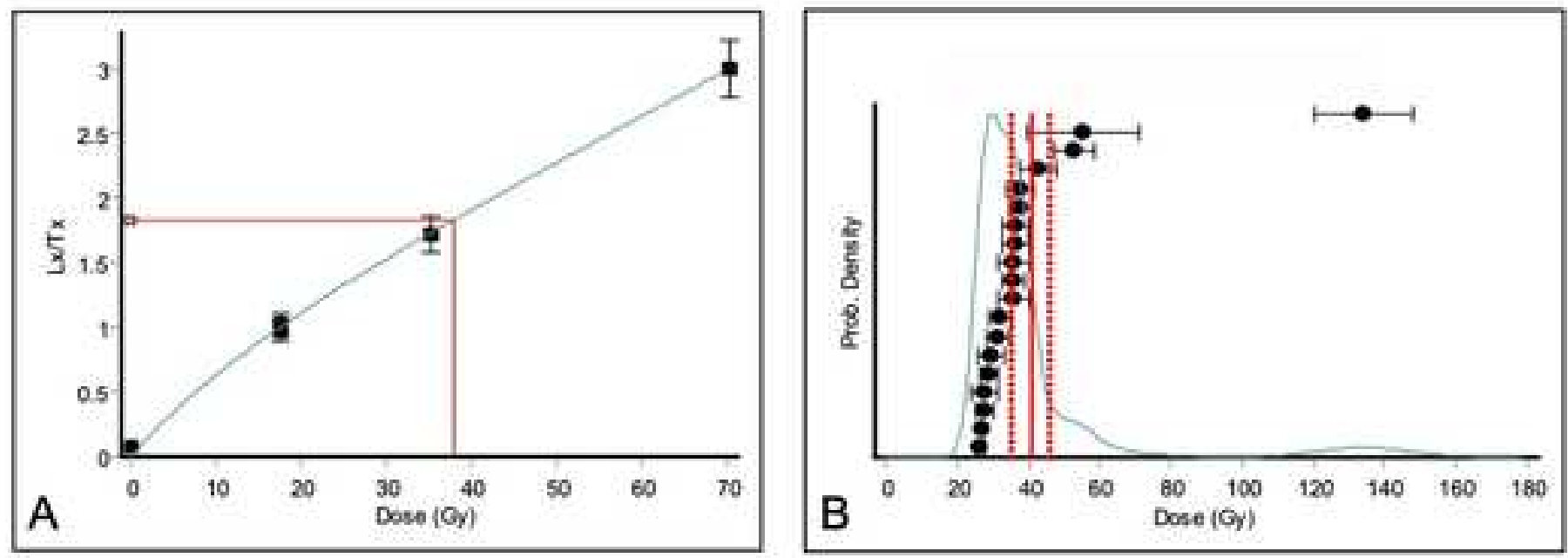

MA16-OSL2
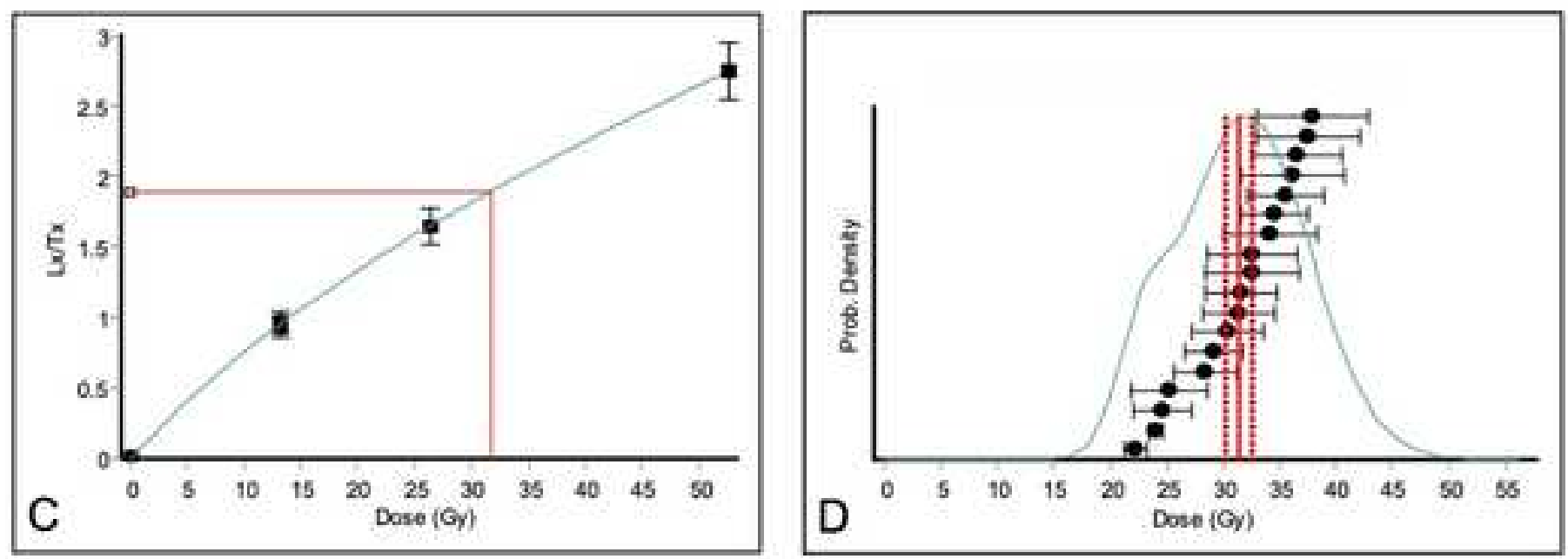

\section{MA16-OSL3}
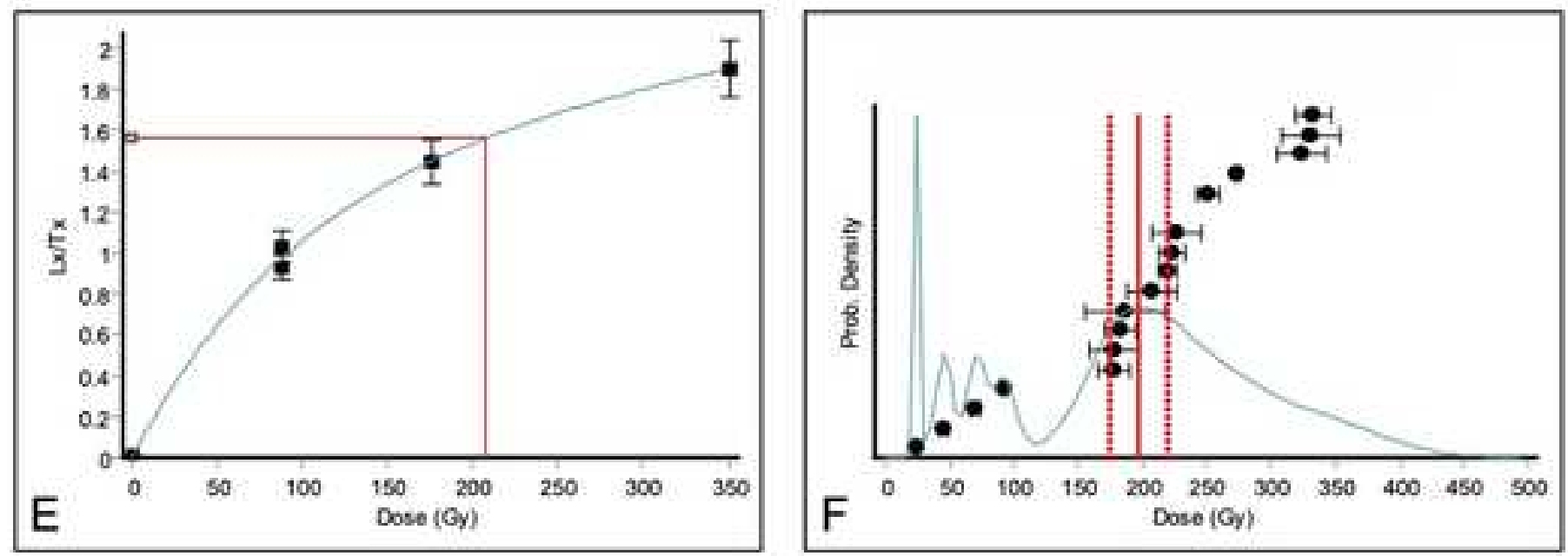


\begin{tabular}{|c|c|c|}
\hline Stratigraphic Unit & Elements & Matrix (\%) \\
\hline P & Rounded pebbles and gravels up to 10cm & Sand - Silt (20\%) \\
\hline SZ & No elements & Clay (100\%) \\
\hline M & Small gravels (up to 2cm) & Clay (95\%) \\
\hline U1 & Angular gravels (up to 3cm) & Clay - Silt (80\%) \\
\hline U1b & Gravel and angular pebbles (up to 3cm) & Clay - Silt (80\%) \\
\hline U2 & Rounded pebbles (0.5 - 10cm) & Sand - Silt (80\%) \\
\hline U3 & Rounded pebbles (0.5 - 20cm) & Sand - Silt (50\%) \\
\hline U4 & Rounded pebbles (up to 10cm) & Clay - Silt (20\%) \\
\hline U5 & Rounded pebbles (up to 10cm) & Silt (20\%) \\
\hline U6 & Rounded pebbles (up to 15cm) & Silt (20\%) \\
\hline U7 & Sparse angular gravels (up to 2cm) & Clay (>99\%) \\
\hline U8 & Graded bedding with rounded pebbles (up to 5cm) & Sand (2\%) \\
\hline U8b & Graded bedding with rounded pebbles (up to 10cm) & Sand (2\%) \\
\hline U9a & Gravel and pebbles (up to 10cm), sand lenses & Silt - Sand ( 50\%) \\
\hline U9b & Rare gravels & Silt - Sand (95\%) \\
\hline U9c & Gravel and pebbles (up to 10cm), sand lenses & Silt - Sand ( 50\%) \\
\hline U10 & Rounded gravels and pebbles & Clay - Silt (70\%) \\
\hline U10b & Rounded blocks, gravel and pebbles & Clay - Silt (50\%) \\
\hline U11 & Angular gravels and pebbles & Clay - Silt (50\%) \\
\hline U12 & Rounded gravels and pebbles (up to 5cm) & Clay - Silt (20\%) \\
\hline U13 & Rounded gravels and sparse rounded pebbles (up to 8cm) & Sand - Silt (80\%) \\
\hline U14 & Rounded gravels and pebbles (up to 10cm) & Sand - Silt (80\%) \\
\hline
\end{tabular}




\begin{tabular}{|c|c|}
\hline Color & Resistivity (ohm.m) \\
\hline Yellow - Grey & 166 \\
\hline Red & N/A \\
\hline Red - Orange & 74 \\
\hline Yellow - Beige & 106 \\
\hline Beige - Orange & N/A \\
\hline Red - Brown & 445 \\
\hline Red - Brown & N/A \\
\hline Brown - Beige & 516 \\
\hline Grey - Beige & 300 \\
\hline Beige & 449 \\
\hline Beige - Yellow & 80 \\
\hline Red - Brown & N/A \\
\hline Red - Brown & N/A \\
\hline Beige - Yellow & 826 \\
\hline Beige - Brown & N/A \\
\hline Beige - Grey & N/A \\
\hline Beige - Brown & 81 \\
\hline Beige-Brown & N/A \\
\hline Brown - Red & N/A \\
\hline Brown - Red & N/A \\
\hline Brown & N/A \\
\hline Brown & N/A \\
\hline
\end{tabular}




\begin{tabular}{|c|c|c|c|}
\hline Sample & Clay & Silt & Sand \\
\hline G-P & 10.99 & 30.64 & 58.37 \\
\hline P Quarry & 5.35 & 32.86 & 61.79 \\
\hline P Road & 10.11 & 37.12 & 52.78 \\
\hline G-SZ & 24.66 & 38.74 & 36.60 \\
\hline G-M & 23.41 & 36.46 & 40.13 \\
\hline G-U1-a & 15.97 & 46.65 & 37.38 \\
\hline G-U1-b & 14.05 & 47.84 & 38.11 \\
\hline G-U1-c & 8.44 & 50.98 & 40.58 \\
\hline G-U1-d & 14.39 & 27.33 & 58.28 \\
\hline G-U1b & 6.45 & 41.31 & 52.24 \\
\hline G-U2 & 9.57 & 29.80 & 60.64 \\
\hline G-U3 & 16.05 & 44.98 & 38.97 \\
\hline G-U4 & 8.74 & 35.18 & 56.08 \\
\hline G-U5 & 16.39 & 45.00 & 38.61 \\
\hline G-U6 & 4.66 & 34.49 & 60.86 \\
\hline G-U7 & 22.49 & 57.84 & 19.67 \\
\hline G-U9 & 9.29 & 67.50 & 23.21 \\
\hline G-U10-a & 10.36 & 31.77 & 57.87 \\
\hline G-U10-b & 14.35 & 59.61 & 26.04 \\
\hline
\end{tabular}




\begin{tabular}{|c|c|c|c|c|c|c|c|c|c|}
\hline & & & & & & \multicolumn{2}{|c|}{ Central Age Model (CAM) } & & \\
\hline Sample & $\%$ Water & $\mathrm{K}(\%)^{\mathrm{b}}$ & $\mathbf{U}(\mathbf{p p m})^{\mathbf{b}}$ & Th $(\mathbf{p p m})^{\mathrm{b}}$ & Total Dose & Equivalent Dose & Age & & \\
\hline information & content $^{\mathrm{a}}$ & & & & $(\mathrm{Gy} / \mathrm{ka})^{\mathrm{c}}$ & $(\mathbf{G y})$ & $(\mathbf{k a})^{\mathrm{e}}$ & $\mathrm{n}^{\mathrm{d}}$ & Scatter $^{\mathrm{e}}$ \\
\hline MA16-OSL1 & $5(30)$ & $0.82 \pm 0.03$ & $1.84 \pm$ & 6.31 & $1.74 \pm 0.09$ & $34.0 \pm 1.4$ & $19.4 \pm 1.0$ & $18(19)$ & $14 \%$ \\
\hline MA16-OSL2 & $4(42)$ & $0.82 \pm 0.03$ & $2.02 \pm 0.20$ & $6.24 \pm 0.34$ & $1.71 \pm 0.07$ & $30.6 \pm 0.8$ & $17.9 \pm 0.7$ & $\mid 18(18)$ & $12 \%$ \\
\hline & & & & & & $179.6 \pm 6.3$ & $149.7 \pm 12.1$ & $15(18)$ & $41 \%$ \\
\hline MA16-OSL3 & $2(18)$ & $0.57 \pm 0.03$ & $0.91 \pm 0.14$ & $4.53 \pm 0.30$ & $1.20 \pm 0.06$ & $235.0 \pm 14.9$ & $195.9 \pm 30.8$ & $13(18)$ & $12 \%$ \\
\hline
\end{tabular}




\begin{tabular}{|c|c|}
\hline \multicolumn{2}{|c|}{ Minimum Age Model (MAM } \\
\hline Equivalent Dose & Age \\
\hline $\mathbf{( G y )}$ & $\mathbf{( k a )}^{\mathbf{f}}$ \\
\hline $28.8 \pm 4.6$ & $16.5 \pm 1.1$ \\
\hline $26.8 \pm 2.5$ & $15.4 \pm 0.9$ \\
\hline $\mathrm{NC}$ & $\mathrm{NC}$ \\
\hline $\mathrm{NC}$ & $\mathrm{NC}$ \\
\hline
\end{tabular}




\begin{tabular}{|c|c|c|c|c|c|c|c|c|}
\hline Sample & Unit & Wall & Trench location & Sample size & $\begin{array}{c}\text { Non-calibrated } \\
\text { age (BP) }\end{array}$ & $\begin{array}{c}\text { Uncertainty } \\
\text { (years) }\end{array}$ & $\begin{array}{c}\text { Cal. BP age } \\
\text { (years) }\end{array}$ & $\begin{array}{c}\text { Calibrated age } \\
\text { (at } 95.4 \%)\end{array}$ \\
\hline $\mathrm{C} 3$ & U3 & North & C11 & $1,5 * 1 \mathrm{~cm}$ & 130 & 30 & $9-275$ & $1675 \mathrm{AD}-1942 \mathrm{AD}$ \\
\hline $\mathrm{C} 10$ & U3 & South & $\mathrm{C} 10$ & $0,5 * 0,5 \mathrm{~cm}$ & 115 & 30 & $12-270$ & $1680 \mathrm{AD}-1939 \mathrm{AD}$ \\
\hline C17 & U10 & South & B16 & $1 * 1 \mathrm{~cm}$ & 1985 & 30 & $1877-1995$ & $47 \mathrm{BC}-74 \mathrm{AD}$ \\
\hline$\overline{\mathrm{C} 18}$ & $\mathrm{U} 2$ & North & D10 & $2 * 1 \mathrm{~cm}$ & 280 & 30 & $284-437$ & $1498 \mathrm{AD}-1795 \mathrm{AD}$ \\
\hline C19 & \begin{tabular}{|l|} 
U10 \\
\end{tabular} & South & B12 & $0,2 * 0,3 \mathrm{~cm}$ & 115 & 30 & $12-270$ & $1680 \mathrm{AD}-1939 \mathrm{AD}$ \\
\hline $\mathrm{C} 21$ & $\mathrm{U} 10 \mathrm{~b}$ & South & $\mathrm{C} 12$ & \begin{tabular}{|l|}
$0,5 * 0,5 \mathrm{~cm}$ \\
\end{tabular} & 1100 & 30 & $951-1063$ & $887 \mathrm{AD}-1013 \mathrm{AD}$ \\
\hline $\mathrm{C} 25$ & U13 & South & $\overline{\mathrm{A} 3}$ & $>2 \mathrm{~cm}$ & 8910 & 50 & $9887-10203$ & $8255 \mathrm{BC}-7846 \mathrm{BC}$ \\
\hline $\mathrm{C} 26$ & U12 & North & $\overline{\mathrm{A} 1}$ & $2 * 1 \mathrm{~cm}$ & 9140 & 50 & $10219-10430$ & $8534 \mathrm{BC}-8271 \mathrm{BC}$ \\
\hline $\mathrm{C} 27$ & $\mathrm{P}$ & South & D9 & $0,1 * 0,2 \mathrm{~cm}$ & 255 & 35 & $148-435$ & $1515 \mathrm{AD}-\ldots$ \\
\hline $\mathrm{C} 28$ & $\bar{P}$ & South & D9 & $0,3 * 0,5 \mathrm{~cm}$ & 25 & 30 & $31-255$ & $1696 \mathrm{AD}-1919 \mathrm{AD}$ \\
\hline $\mathrm{C} 29$ & U1 & North & $\mathrm{C} 7$ & $1 * 0,2 \mathrm{~cm}$ & 45 & 30 & $31-257$ & 1694AD - 1919AD \\
\hline $\mathrm{C} 35$ & $\mathrm{U} 2$ & South & D11 & $2 * 1 \mathrm{~cm}$ & 295 & 30 & $292-459$ & $1491 \mathrm{AD}-1659 \mathrm{AD}$ \\
\hline $\mathrm{C} 36$ & U9 & North & B2 & $0,2 * 0,1 \mathrm{~cm}$ & 8820 & 100 & $9593-10180$ & $8232 \mathrm{BC}-7615 \mathrm{BC}$ \\
\hline C37 & $\mathrm{U} 2$ & North & B8 & $0,2 * 0,1 \mathrm{~cm}$ & 340 & 30 & $311-480$ & $1470 \mathrm{AD}-1640 \mathrm{AD}$ \\
\hline C39 & U3 & North & $\bar{D} 13$ & $<1 \mathrm{~mm}$ & 2720 & 50 & $2750-2925$ & $977 \mathrm{BC}-801 \mathrm{BC}$ \\
\hline C41 & U10 & North & A11 & $3 * 2 \mathrm{~cm}$ & 35 & 30 & $31-255$ & $1695 \mathrm{AD}-1919 \mathrm{AD}$ \\
\hline $\mathrm{C} 43$ & U10 & North & A11 & $1 * 0,5 \mathrm{~cm}$ & 75 & 30 & $27-259$ & $1690 \mathrm{AD}-1925 \mathrm{AD}$ \\
\hline C44 & U7 & North & B16 & $2 * 1 \mathrm{~cm}$ & 2050 & 20 & $1947-2064$ & $166 \mathrm{BC}-20 \mathrm{AD}$ \\
\hline C49 & U7 & South & $\mathrm{C} 15$ & $0,2 * 0,1 \mathrm{~cm}$ & 2445 & 35 & $2358-2703$ & $755 \mathrm{BC}-409 \mathrm{BC}$ \\
\hline$\overline{\mathrm{C} 50}$ & U13 & South & $\overline{\mathrm{A} 2}$ & $3 * 3 \mathrm{~cm}$ & 8890 & 50 & $9883-10190$ & $8242 \mathrm{BC}-7836 \mathrm{BC}$ \\
\hline
\end{tabular}




\begin{tabular}{|c|}
\hline Identification \\
\hline Undertermined (parenchyma) \\
\hline Deciduous oak (cf Quercus pubescens ) \\
\hline Deciduous oak (cf Quercus pubescens ) \\
\hline Buxus sempervirens (Boxwood) \\
\hline Deciduous oak (cf Quercus pubescens ) \\
\hline Undetermined charcoal \\
\hline Not determinable hardwood (Angiosperm) \\
\hline Deciduous oak (cf Quercus pubescens ) \\
\hline (Juniper. Identification to the species is impossible) \\
\hline Auniperus sp. (Maple. Identification to the species is impossible) \\
\hline Cistus sp. (Rockrose. Identification to the species is impossible) \\
\hline Not determinable hardwood (Angiosperm) \\
\hline Undetermined charcoal \\
\hline Undetermined charcoal \\
\hline Cotinus coggyria (« Wig tree ») \\
\hline Sclerophyllous oak : evergreen oak (Quercus ilex) or Kermes oak (Q. coccifera ) \\
\hline Deciduous oak (cf Quercus pubescens ) \\
\hline Undetermined (parenchyma) \\
\hline
\end{tabular}

